Historic, Archive Document

Do not assume content reflects current scientific knowledge, policies, or practices. 



\section{Littlefield-Wyman Nurseries}

OFFICE AND GREENHOUSE

423 Adams Street

North Abington, Mass.

Telephone: Rockland 1200

SHIPPING SHED

227 Centre Avenue Abington, Mass.

Near Abington Passenger and Freight Station

G We offer to our clients a complete LANDSCAPE DEVELOPMENT and PLANTING SERVICE.

That this service is economical and highly satisfactory is attested to by the large number of testimonials we have on file. Whether your requirements be a small foundation planting or an estate development, let us give you an estimate.

Visitors are always welcome, but we are not open for business on Sundays.

ROAD MAP TO OUR NURSERIES

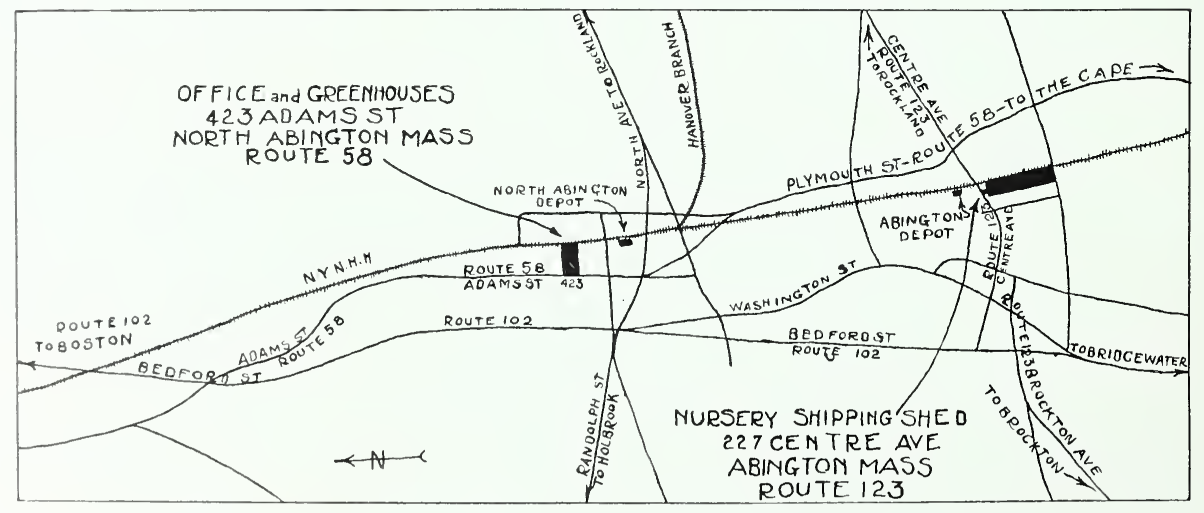




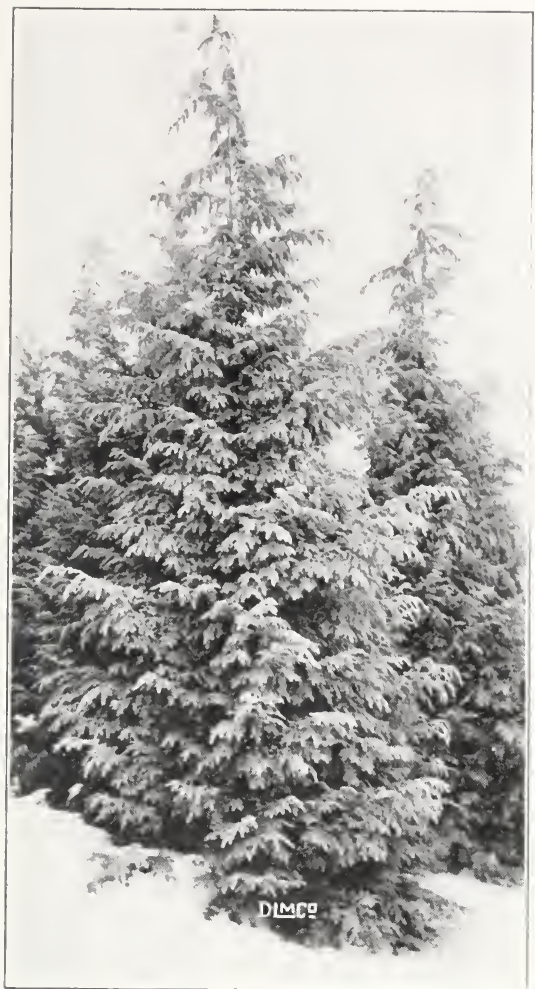

Tsuga canadensis (Canada Hemlock). See page 7

\section{Evergreen Trees}

"We dream of vistas 'mid the croulding snou's, W'ith Fvergreens along the northern line-

The Pines and Cedars when the cold wind blows Through all their branches with a constant whine.'

$\mathrm{E}$ ERGREEN trees when received from the Nursery are balled and burlapped. Our experience proves to us that Evergreens handled this way (B\&B) can be planted as soon as the frost leaves the ground in Spring, and right through the Summer and Fall until the ground is frozen again.

When planting Evergreens, dig the hole eight to ten inches larger than the ball, and about one inch deeper. Remove burlap and set tree in the hole. Step back and see if the plant is straight and placed to the best advantage in relation to other plants and surroundings. Now fill the hole almost full of soil, and then fill with water. After the water has soaked down, fill completely with soil and tramp it down until it is firm and level.

At all times keep the soil cultivated. In dry weather, water at intervals of seven to ten days. Water thoroughly and see that it penetrates well down to the roots. Watering a little every day does more harm than good. Evergreens will grow in any good garden soil. Use fertilizer sparingly.
ABIES concolor. White Fir. $50-75 \mathrm{ft}$. A superb showy lawn specimen of stately, symmeterical growth. Foliage green to grayish blue.

\begin{tabular}{lrr}
$5-6 \mathrm{ft}$ & $\begin{array}{r}\text { Each } \\
15.00\end{array}$ & \multicolumn{1}{c}{10} \\
$4-5 \mathrm{ft}$ & 11.00 & \\
$3-4 \mathrm{ft}$ & 8.00 & $\$ 75.00$ \\
$212^{-3} \mathrm{ft}$ & 6.00 & 55.00 \\
$2-2{ }^{1} \mathrm{ft}$ & 4.00 & 35.00 \\
$1 \mathrm{~S}-24 \mathrm{in}$ & 3.00 & $\ldots$
\end{tabular}

CHAMAECYPARIS obtusa. Ilinoki Cypress, 14-1S $\mathrm{ft}$. Pyramidal, compact growth, with dark fernlike foliage.

$$
\begin{aligned}
& 31 / 2-4 \mathrm{ft} \\
& 3-31 / 2 \mathrm{ft} \\
& 21 / 2-3 \mathrm{ft} \\
& 2-21 / 2 \mathrm{ft} \\
& 19-24 \mathrm{in}
\end{aligned}
$$

Each

5.00

5.00

3.75

3.00

2.00

C. obtusa grasilis. Slender IIinoki Cypress. 10-14 ft. Pyramidal in shape, with rich, green feathery foliage.

$$
\begin{aligned}
& 3-3^{1}{ }_{2} \mathrm{ft} \\
& 21-3 \mathrm{ft} \\
& 2-2^{1} \mathrm{ft} \\
& \text { Each } \\
& 6.00 \\
& +.50
\end{aligned}
$$

C. obtusa nana. Düurf Hinoki Cypress, 2-3 ft. Almost spherical in shape. Holds its color well in Winter. Slow growing.

$\begin{array}{rrr}18-24 \text { in . . } & \begin{array}{c}\text { Each } \\ \$ 4.00\end{array} & 10 \\ 15-18 \text { in } & 3.00 & \$ 27.00 \\ 12-15 \text { in } & 2.25 & 20.00 \\ 9-12 \text { in } & 1.50 & 13.50\end{array}$

Abbreviations: Suitable for Rock ( Garckens (R) Suitable for Sea Shore Attracts Bircls 
CHAMAECYPARIS - Continued

C. pisifera Suivara Retinospora. 20-30 ft. Ideal for a formal specimen. Tall, with broad, flat, glossy green foliage.

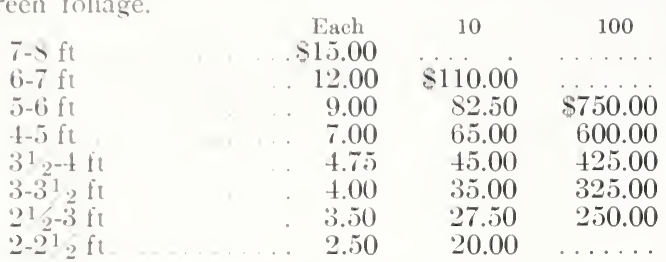

C. pisifera filifera. Thread Retinospora. $14-18 \mathrm{ft}$. Dense, dark green threadlike pendulous branches of lovely light green foliage. A graceful low tree.

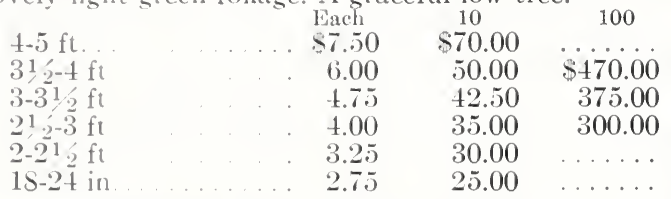

C. pisifera filifera aurea. Goldenthread Retinospora. 10-12 ft. Vividly golden foliage in the above form.

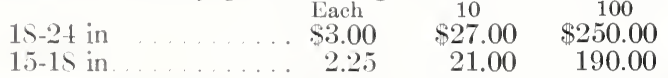

C. pisifera plumosa. Plume Retinospora. $25-35 \mathrm{ft}$. Soft feathery branchings that respond to shearing. Excellent for formal work or as a hedge.

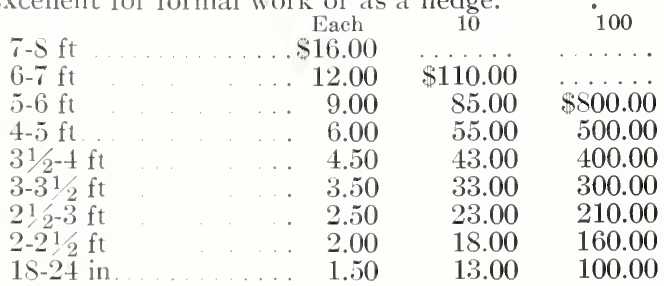

C. pisifera plumosa argentea. Silvertip Retinospora. 25-30 ft. Greenish blue foliage with silver tips.

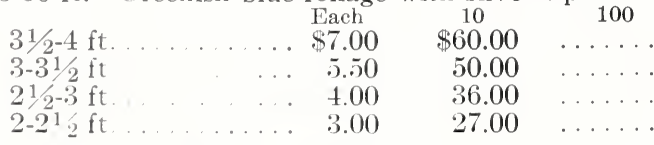

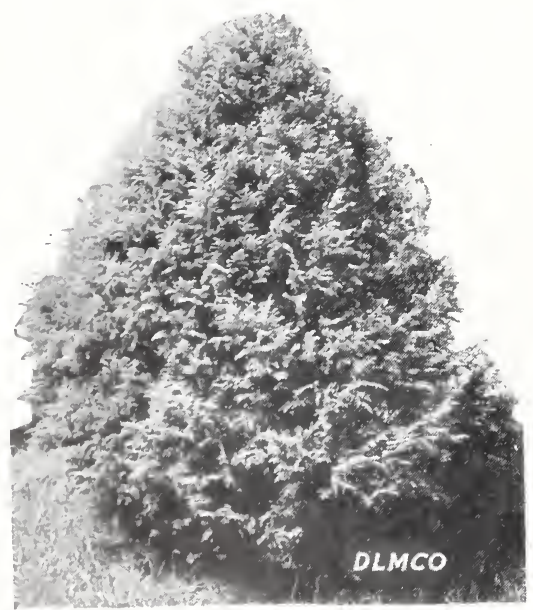

Chamaecyparis pisifera plumosa

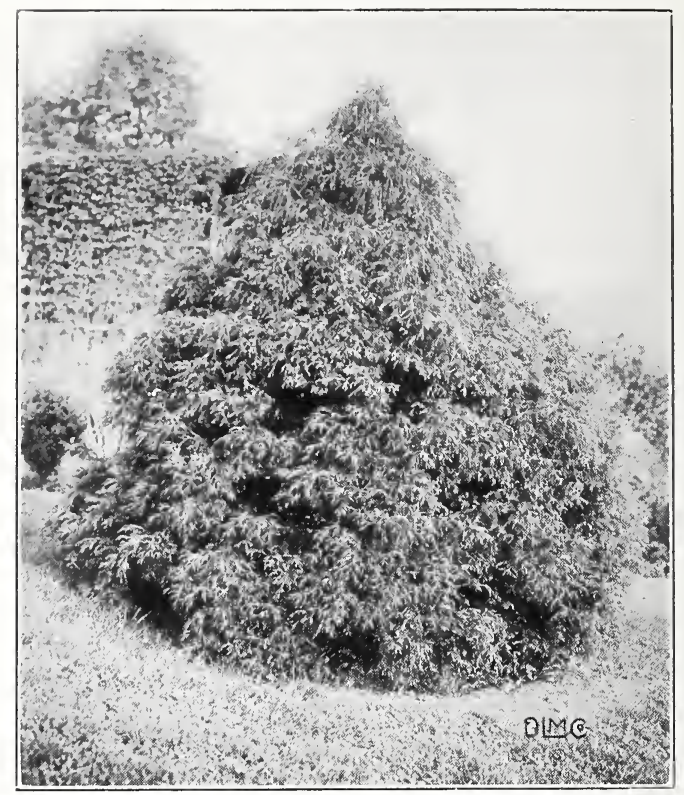

Chamaecyparis pisifera filifera (Thread Retinospora)

C. pisifera plumosa aurea. Goldenplume Retinospora. $20-25 \mathrm{ft}$. A strikingly individual form which makes an interesting contrast against the usual green of $\begin{array}{llll}\text { evergreens. } & \text { Each } & 10 & 100\end{array}$

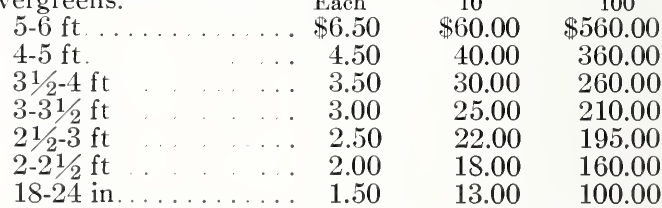

C. pisifera squarrosa. Moss Retinospora. $25-30 \mathrm{ft}$. Silver blue in color. Broadly pyramidal, soft and graceful.

$31 / 2-4 \mathrm{ft}$

$3-31 / 2 \mathrm{ft}$

Each

$\$ 60.00$

100

$21 / 2-3 \mathrm{ft}$
$2-21 / 2 \mathrm{ft}$

5.50

50.00

450.00

$4.00 \quad 36.00 \quad 300.00$

$3.00 \quad 27.00 \quad \ldots \ldots$.

JUNIPERUS chinensis pfitzeriana. Pfitzer Juniper. 5-6 ft. (S) A success everywhere. This remarkable evergreen is as broad as it is tall; soft gray-green feathery foliage. $\quad$ Each $10 \quad 100$ $4-5$ ft. spread . . . . \$12.00 \$110.00 $\$ 1080.00$ $\begin{array}{rrrr}31 / 2-4 \text { ft. spread } \ldots . . & 9.00 & 85.00 & 800.00\end{array}$ $3-31 / 2$ ft. spread . . . . $6.50 \quad 600000$

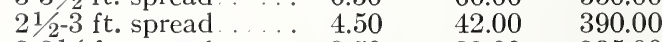
$\begin{array}{llll}2-21 / 2 \mathrm{ft} \text {. spread . . . . . } & 3.50 & 32.00 & 285.00\end{array}$ 18-24 in. spread.... $3.00 \quad 27.00 \quad 240.00$

J. communis aurea. Golden Juniper. $1-1 \frac{1}{2} \mathrm{ft}$. (R) Brilliant golden hue throughout season. Splendid for rockeries, or as a contrast in front of evergreen borders.

$3-3 \frac{1}{2} \mathrm{ft}$ spread

Each

$\ldots \ldots \ldots \ldots \ldots .50$

$15-18$ in. spread. . . . . . . . . . . . .

J. communis hibernica. Irish Juniper. $7-8 \mathrm{ft}$. (B) A tall columnar form of great dignity. Leaves are $\begin{array}{llll}\text { gray-green. } & \text { Each } & 10 & 100\end{array}$

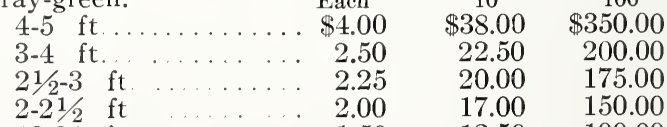
$\begin{array}{llll}18-24 & \text { in . . . . . . . } 1.50 & 12.50 & 100.00\end{array}$ 


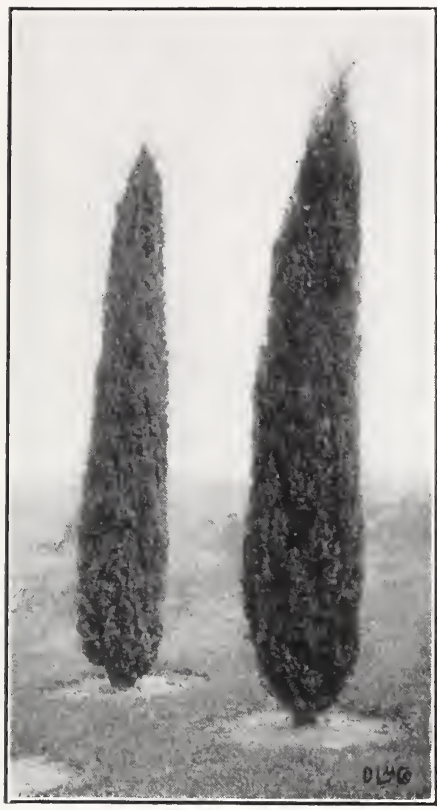

Juniperus communis hibernica (Irish Juniper). See page?

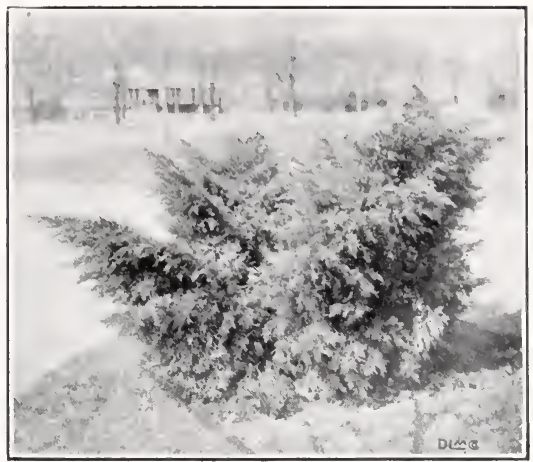

Juniperus chinensis pfitzeriana (Pfitzer Juniper). See page 2

\section{JUNIPERUS Continued}

J. communis suecica. Swedish Juniper. 9-10 ft. (B) Another even taller columnar variety. Perfect for formal use. Prickly light green needles.

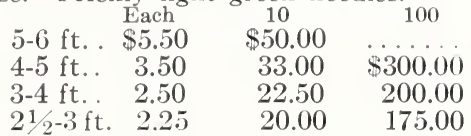

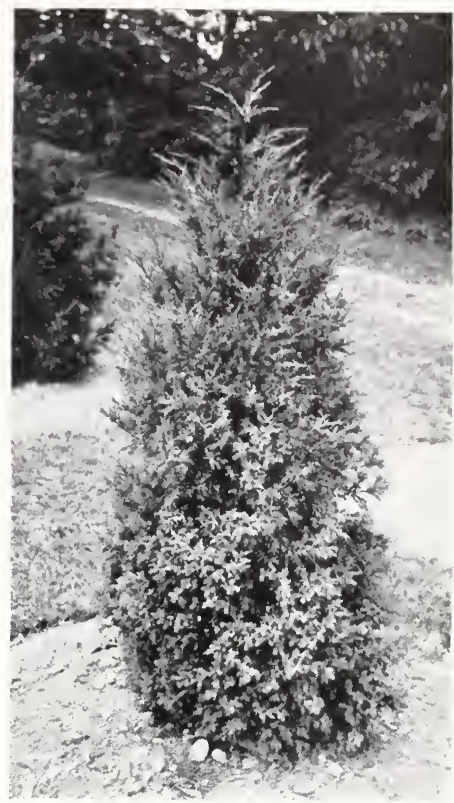

Juniperus virginiana (Redcdear)
J. communis seucica. Upright Compact Swedish Juniper. 9-10 ft. Similar to above but more compact.

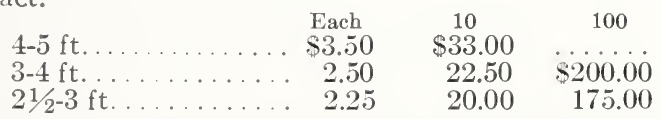

J. excelsa stricta. Spiny Greek Juniper. $t_{-5} \mathrm{ft}$. Steel blue, small, perfectly pyramidal tree of dense foliage.

\begin{tabular}{|c|c|c|c|}
\hline & Each & $\begin{array}{l}10 \\
\$ 6300\end{array}$ & 100 \\
\hline & 5.00 & 45.00 & $\$+25.00$ \\
\hline $\mathrm{ft}$. & 3.75 & 35.00 & 325.00 \\
\hline & 2.75 & 24.00 & 210.00 \\
\hline & 2.25 & 20.00 & 180.00 \\
\hline & 1.75 & 15.00 & 125.00 \\
\hline
\end{tabular}

J. horizontalis. Creeping Juniper. $1-11 / 2 \mathrm{ft}$. (R) Unexcelled for rock gardens, slopes or banks, because of its tendency to fairly hug the ground. Thrives in sandy soil.

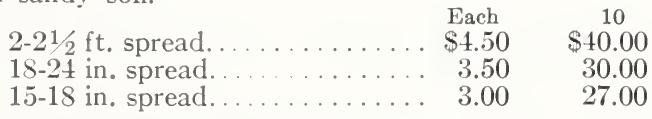

J. horizontalis douglasi. Waukegan Juniper. 1-11/2 ft. (R-S) Deep green foliage in low growing, spreading type. Exceptionally fine.

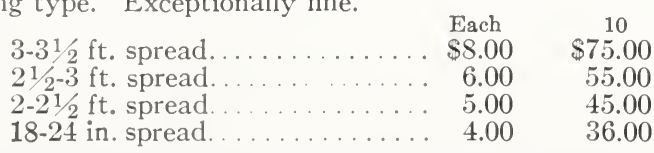

J. japonica albovariegata. Whiteleaf Chinese Juniper. 18 in. to $2 \mathrm{ft}$. Compact, dense, needle type foliage. Dark steel gray green, with occasional yellow-white tips.

$2-21 / 2 \mathrm{ft}$. spread

Each

18-24 in. spread
J. sabina. Savin Juniper. 6-7 ft. (S-R) An interesting fanlike growth makes this evergreen invaluable for rockeries. $3-31 / 2 \mathrm{ft}$. spread. $21 / 2-3 \mathrm{ft}$. spread $2-21 / 2 \mathrm{ft}$. spread $18-24$ in. spread. $15-18$ in. spread. $12-15$ in. spread.

\begin{tabular}{rrr} 
Each & 10 & \multicolumn{1}{c}{100} \\
$\$ 5.00$ & $\$ 17.50$ & $\$ 450.00$ \\
4.00 & 36.00 & 330.00 \\
3.00 & 26.00 & 225.00 \\
2.50 & 20.00 & 180.00 \\
2.00 & 18.00 & 150.00 \\
1.50 & 12.00 & 90.00
\end{tabular}

J. sabina tamariscifolia. Tamarix Savin Juniper. $1-11 / 2 \mathrm{ft}$. (R-S) Queer and fascinating in its wide spreading growth to 6 or $8 \mathrm{ft}$. Blue-green feathery foliage.

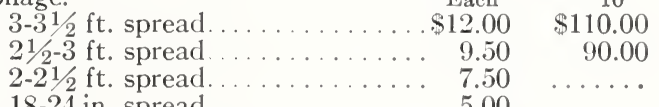

18-24 in. spread.

5.00

J. virginalis globosa. Globe Chinese Juniper. $3-4 \mathrm{ft}$. (R) Dwarf globe-shape Chinese Juniper with dark green feathery foliage.

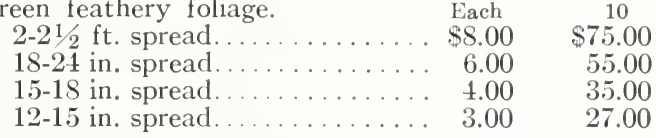

J. virginiana. Redcedar. 25-30 ft. (B-S) Tall, slender, pyramidal tree needed in practically every planting. Very hardy. Each

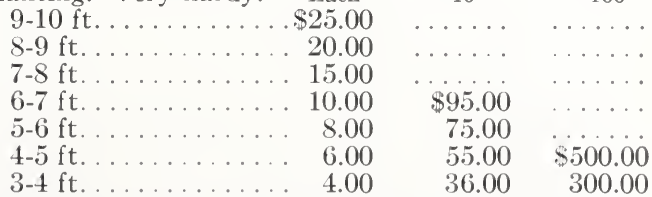

J. virginiana glauca. Silver Redcedar. 15-20 ft. (B-S) Outstandlingly popular because of its silvery color and graceful feathery tipped branchlets. Each 10

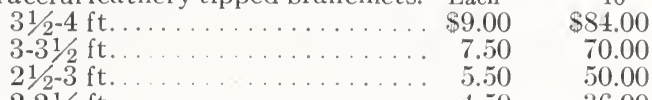

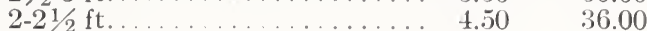


PICEA canadensis. White Spruce. $50-60 \mathrm{ft}$. (S) A stately densely growing tree of light green foliage, slightly tinged with blue.

\begin{tabular}{|c|c|c|c|}
\hline & Each & 10 & 100 \\
\hline & $s t$. & $\$ 35.00$ & $\$ 300.00$ \\
\hline & 3.00 & 25.00 & 200.00 \\
\hline & 2.00 & 15.00 & 150.00 \\
\hline & 1.50 & 12.00 & 99.00 \\
\hline
\end{tabular}

P. excelsa. Vorialy Spruce. $\$ 0-100 \mathrm{ft}$. (S). The usual Christmas tree. Vigorous and thoroughly dependable as a windbreak, hedge or screen.

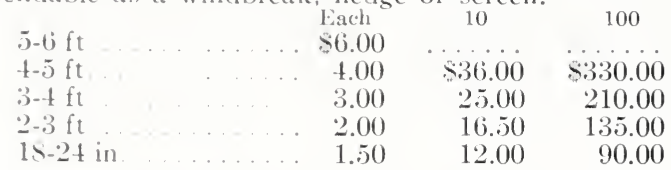

P. glauca conica. Düarf .1lberta Spruce. $4-5 \mathrm{ft}$. (R-S) Low, dense, conical, and of exceptionally high merit for rockeries or for any place where a permanent low evergreen is desired.

\begin{tabular}{|c|c|c|c|}
\hline 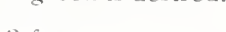 & Each & 10 & 100 \\
\hline $3 \mathrm{ft}$. & $\$ 15.00$ & $\$ 140.00$ & \\
\hline $2{ }^{1} 2-3 \mathrm{ft}$ & 8.00 & 75.00 & $\$ 720.00$ \\
\hline $2-2^{1}{ }_{2} \mathrm{ft}$ & 6.00 & 55.00 & 510.00 \\
\hline $21-24$ in & 5.00 & 45.00 & +20.00 \\
\hline $15-21 \mathrm{in}$ & 4.00 & 36.00 & 330.00 \\
\hline $15-18$ in. & 3.00 & 27.00 & 250.00 \\
\hline $15 \mathrm{in}$. & 2.50 & 23.00 & 210.00 \\
\hline $12 \mathrm{in.}$ & 2.00 & 18.00 & 150.00 \\
\hline
\end{tabular}

P. mariana. Black Spruce. 20-30 ft. The native Black Spruce. Slender, almost pendulous branches; very distinctive.

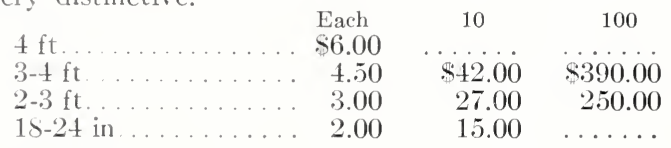

P. pungens. Colorado Spruce. 60-80 ft. (S). Noted for hardiness, symmetry, light green to blue foliage.

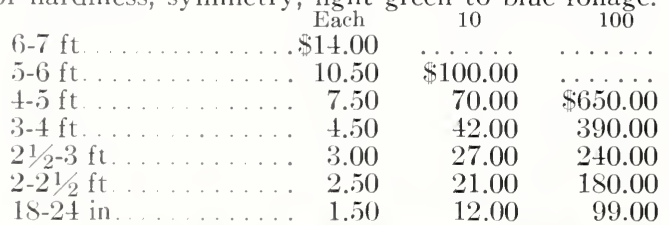

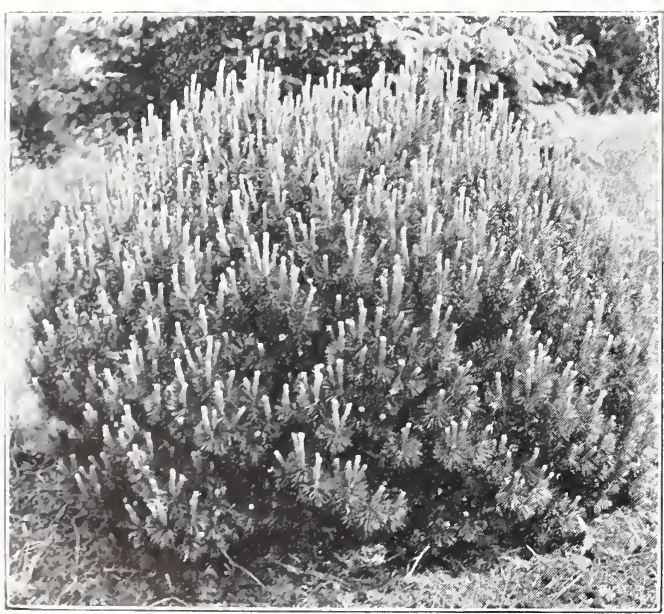

Pinus montana mughus (Mugho Pine)

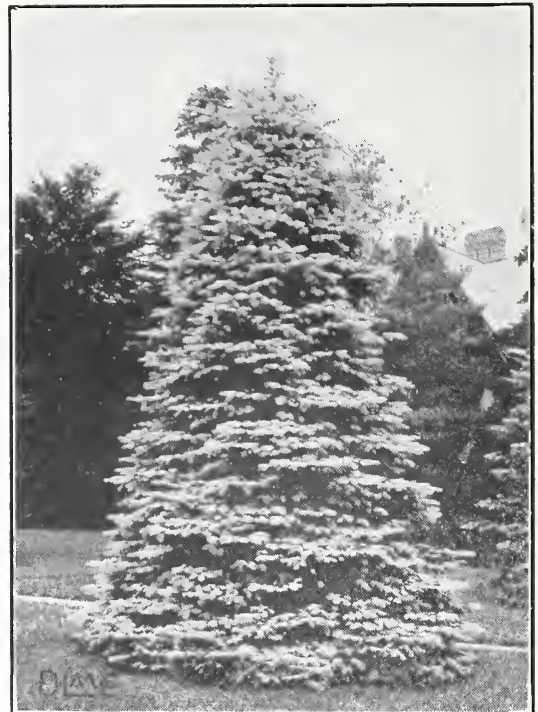

Picea pungens glauca (Blue Colorado Spruce)

P. pungens glauca. Blue Colorado Spruce. $60-80 \mathrm{ft}$ (S). The King of Spruces; some say the ultimate in beautiful evergreens. Very blue in color.

\begin{tabular}{|c|c|c|c|}
\hline $5-6 \mathrm{ft}$ & $\begin{array}{c}\text { Each } \\
\$ 16.00\end{array}$ & 10 & 100 \\
\hline & 12.00 & $\$ 114.00$ & $\$ 1110.00$ \\
\hline & 8.50 & 80.00 & 750.00 \\
\hline & 5.50 & 51.00 & 480.00 \\
\hline $1 / 0 \mathrm{f}$ & 4.5 & 40.00 & 360.00 \\
\hline & 3.50 & 32.40 & 300.00 \\
\hline
\end{tabular}

PINUS cembra. Swiss Stone Pine. Thickly foliaged with gray-green needles. Fine conical shape, and suitable for foundation plantings.

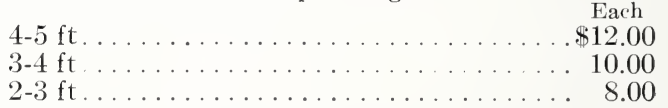

P. densiflora. Japanese Red Pine. 40-50 ft. (S). Long, light green needles; branchlets orange-yellow and Chestnut-brown buds.

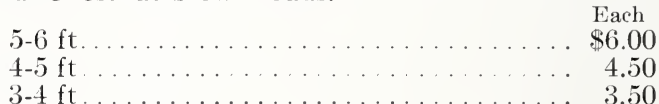

P. montana mughus. Mugho Pine. 21/2-4 ft. (S). This dwarf evergreen achieves immediate interest in your planting. Very low, shrubby, compact and hardy. The true type. Highly recommended.

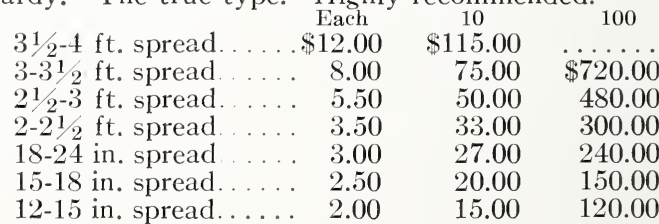

P. nigra. Austrian Pine. 60-70 ft. (S). A rugged, stately Pine, rapid in growth and very hardy.

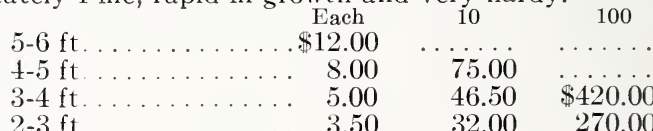




\section{PINUS-Continued}

P. resinosa. Red Pine. 60-70 ft. Light green, longneedled foliage, with reddish-brown bark. Graceful and hardy.

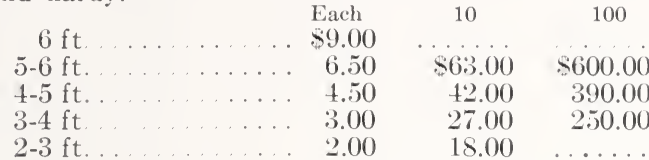

P. strobus. White Pine. $80-100 \mathrm{ft}$. The largest of the cone-bearing Pines; Hexible, long needles, white underneath; dignified as a lawn specimen.

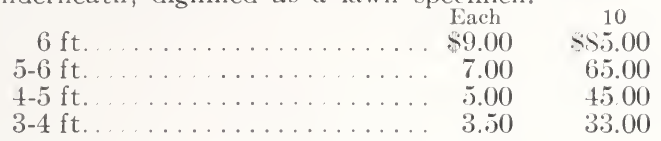

P. sylvestris. Scotch Pine. 60-70 ft. (S). A picturesque rather than beautiful tree. Seldom grows straight; oblique branches: quick growing and hardy.

\begin{tabular}{rrrr}
$6 \mathrm{ft} \ldots \ldots \ldots \ldots \ldots \ldots$ & $\$ 9.00$ & $\$ 85.00$ & \multicolumn{1}{c}{100} \\
$5-6 \mathrm{ft} \ldots \ldots \ldots \ldots \ldots$ & 6.00 & 57.00 & $\$ 540.00$ \\
$4-5 \mathrm{ft} . \ldots \ldots \ldots \ldots \ldots$ & 4.50 & 42.00 & 390.00 \\
$3-4 \mathrm{ft} \ldots \ldots \ldots \ldots \ldots$ & 2.50 & 21.00 & 180.00 \\
$2-3 \mathrm{ft} \ldots \ldots \ldots \ldots \ldots$ & 2.00 & 16.50 & 120.00
\end{tabular}

PSEUDOTSUGA douglasi. Douglas Fir. $70-80 \mathrm{ft}$. Characteristic of both Spruces and Hemlocks. A magnificent tree for use as a lawn specimen.

\begin{tabular}{|c|c|c|c|}
\hline & $\begin{array}{l}\text { Each } \\
\$ 9.00\end{array}$ & $\begin{array}{l}10 \\
\$ 85.00\end{array}$ & 100 \\
\hline 8 & 6.00 & 57.00 & $\$ 540.00$ \\
\hline & 4.00 & 36.00 & 330.00 \\
\hline 2 & 3.00 & 7.00 & \\
\hline
\end{tabular}

TAXUS baccata washingtoni. Washington Yew. 4-6 ft. A handsome and rare variety with fine golden foliage. Very hardy.

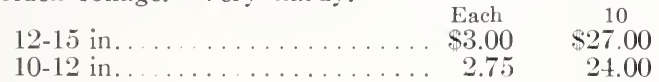

T. canadensis. Canada Yew. 2-21/2 ft. Low spreading, with thrifty dark green foliage, changing to bronze in Winter, with crimson berries. Thrives in partial shade.

\begin{tabular}{|c|c|c|c|}
\hline & Each & 10 & 100 \\
\hline spre & $\$ 4.00$ & $\$ 36.00$ & \\
\hline 1 & 3.00 & 27.00 & $\$ 240.00$ \\
\hline$s 0$ & 2.50 & 21.00 & 180.00 \\
\hline sprs & 2.00 & 18.00 & 150.00 \\
\hline
\end{tabular}

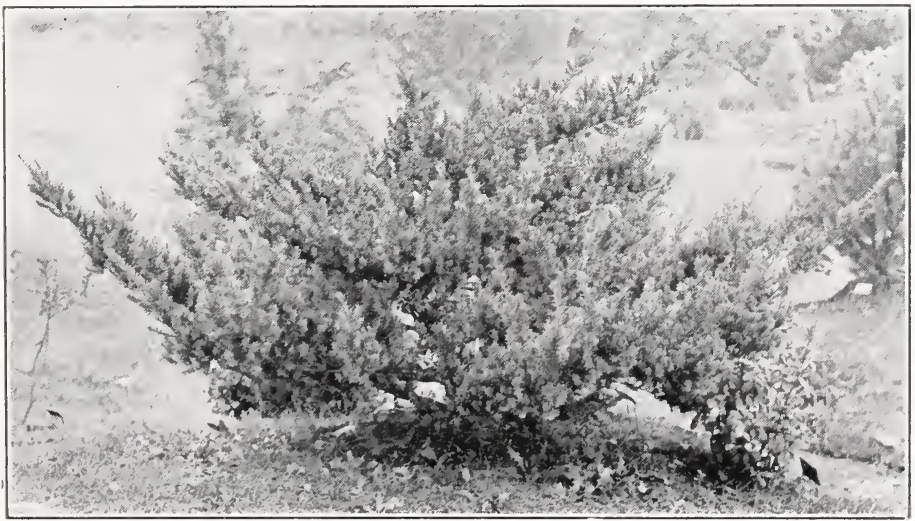

Taxus cuspidata (Japonese Yew)

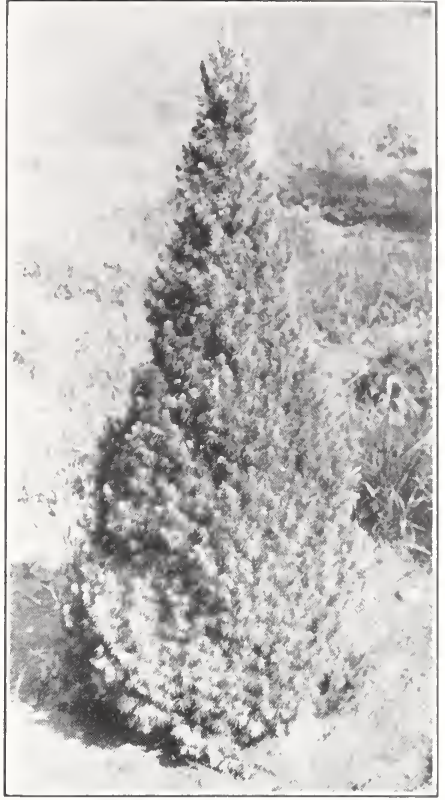

Picea glauca conica (Dwarf Albertr Spruce). See page 4

T. cuspidata. Japanese Yew. 5-s ft. (B-S). Like the above, only slow growing, with dark green, almost black, foliage, retaining its color throughout the Vinter. Spreading type.

\begin{tabular}{|c|c|c|c|}
\hline & Each & & 100 \\
\hline$-3 \mathrm{ft} . \mathrm{spr}$ & $\$ 9.00$ & $\$ 85.00$ & \\
\hline$-21 / 2 \mathrm{ft}$. spread. & 6.00 & 55.00 & $\$ 500.00$ \\
\hline $18-24$ in. spread. & 4.00 & 35.00 & 300.00 \\
\hline $15-18$ in. spread. & 3.00 & 25.50 & 210.00 \\
\hline $12-15$ in. spread. & 2.25 & 19.50 & 165.00 \\
\hline
\end{tabular}

T. cuspidata nana. Dwarf Japanese Yew. 4-6 ft. (S-R). Upright compact form, with short, dark green foliage throughout year. Odd appearing, but grows old gracefully.

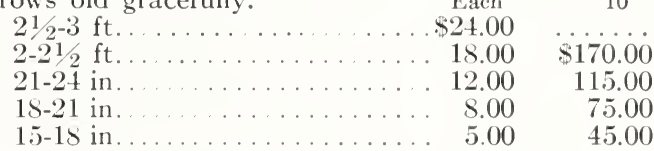

T. cuspidata nana. Spreading Dwarf Japanese Yew. 3-5 ft. (S-R). Like the above, only low growing instead of pyramidal.

\begin{tabular}{|c|c|c|c|}
\hline read $\mathrm{F}$ & ach & 10 & 100 \\
\hline $21 / 2 \mathrm{ft}$. . & $\$ 17.00$ & $\$ 165.00$ & \\
\hline $21-24$ in.. & 10.00 & 95.00 & \\
\hline $18-21$ in.. & 7.00 & 65.00 & $\$ 600.00$ \\
\hline 18 in.. & 4.00 & 35.00 & 300.00 \\
\hline $2-15$ in.. & 3.00 & 27.00 & 240.00 \\
\hline
\end{tabular}

THUJA occidentalis. American 1 rborvitae. 20-30 ft. (S). Perfect for ornamental hedges. Responds to clipping; dense columnar growth with flattened lacelike sprays.

$\begin{array}{lrrr}7-8 \mathrm{ft} . \ldots & \$ 9.00 & \$ 85.00 & \$ 800.00 \\ 6-7 \mathrm{ft} . \ldots & 7.00 & 65.00 & 630.00 \\ 5-6 \mathrm{ft} \ldots & 5.50 & 50.00 & 450.00 \\ 4-5 \mathrm{ft} . \ldots & 3.50 & 30.00 & 270.00 \\ 3-4 \mathrm{ft} . \ldots & 2.50 & 21.00 & 180.00 \\ 2-3 \mathrm{ft} . \ldots & 1.80 & 15.00 & 120.00\end{array}$




\section{THUJA Continued}

T. occidentalis douglasi pyramidalis. Douglas Pyramidal Arborvitae. 20-30 ft. (S). Dark foliage in perfect pyramidal form. Excellent for formal or parterre garden effects. Each $10 \quad 100$

\begin{tabular}{|c|c|c|c|c|c|}
\hline$-\mathrm{s} \mathrm{ft}$. & . & & .815 .00 & $\$ 135.00$ & \\
\hline b. $-7 \mathrm{ft}$ & & & 10.00 & 96.00 & $\$ 930.00$ \\
\hline$-6 \mathrm{ft}$ & & & 7.50 & 70.00 & 660.00 \\
\hline jf & & & 6.00 & 55.00 & 510.00 \\
\hline $\mathrm{ft}$ & & & +.00 & 36.00 & 300.00 \\
\hline & & & 3.00 & 27.00 & $2 \pm 0.0$ \\
\hline $1 \mathrm{ft}_{\mathrm{t}}$ & & & 2.00 & 18.00 & 150. \\
\hline
\end{tabular}

Thuja occidentalis ellwangeriana. Tom Thumb Arboritue. 12-15 ft. Slow growing, low, broad, compact variety. Soft, light green, feathery foliage.

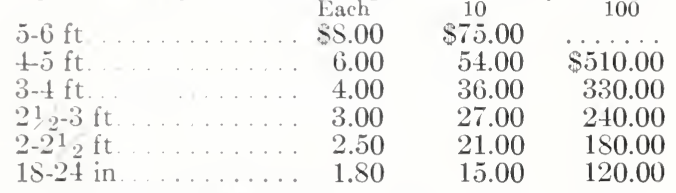

T. occidentalis fliformis. Threadleaf Arborvitae. 20-30 ft. Unique variety with long thread-like foliage. Distinctly Japanese in effect. Each
$3-3^{1} \frac{1}{2} \mathrm{ft}$
$21 / 2-3 \mathrm{ft}$
$\$ 12.00$
9.00

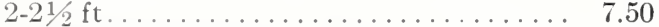

T. occidentalis globosa. American Globe Arborvitae. $5-6 \mathrm{ft}$. (R-S). Splendid for formal effects and rockeries. A dense ball-like form.

\begin{tabular}{|c|c|c|c|}
\hline 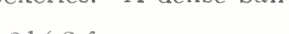 & Each & 10 & 100 \\
\hline $21 / 2-3 \mathrm{ft}$. & $\$ 4.00$ & $\$ 36.00$ & \\
\hline $2-21 / 2 \mathrm{ft}$. & 3.00 & 24.00 & $\$ 195.00$ \\
\hline $15-2+$ in & 2.00 & 16.50 & 135.00 \\
\hline in & 1.50 & 12.00 & 100.00 \\
\hline $12-15$ in $\ldots \ldots \ldots \ldots$ & 1.35 & 10.50 & 84.00 \\
\hline
\end{tabular}

T. occidentalis hoveyi. Hovey Arborvitae. $5-6 \mathrm{ft}$. A somewhat dwarf form of fresh light green color slightly golden.

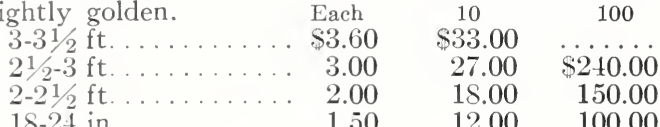

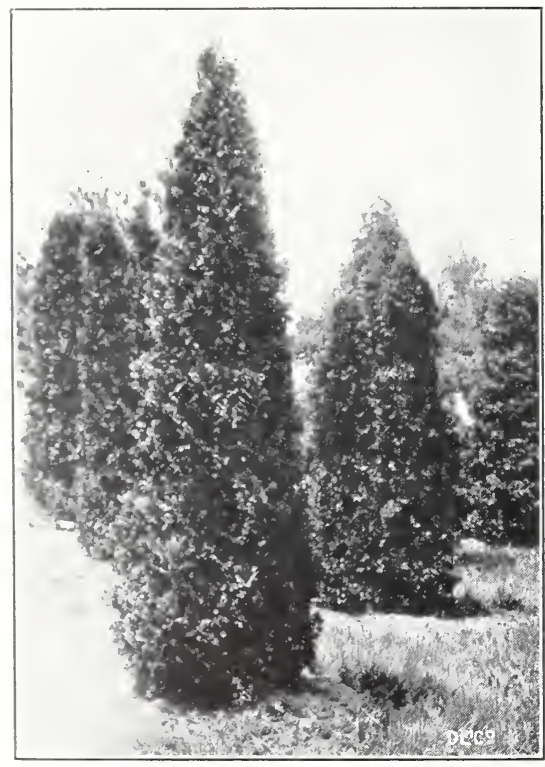

Thuja occidentalis pyramidalis (American Pyramidal Arboritae)
T. occidentalis lutea. George Peabody Arborvitae. $10-15 \mathrm{ft}$. A beautiful pyramidal variety with bright yellow or golden foliage.

\begin{tabular}{|c|c|c|c|}
\hline 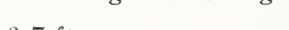 & Each & 10 & 100 \\
\hline $6-7 \mathrm{ft}$ & $\$ 8.00$ & $\$ 75.00$ & $\cdots$ \\
\hline $5-6 \mathrm{ft}$. & 6.00 & 54.00 & . \\
\hline $4-5 \mathrm{ft}$ & 4.00 & 35.00 & \\
\hline $\mathrm{ft}$ & 3.50 & 31.50 & $\$ 270.00$ \\
\hline $3 \mathrm{ft} \ldots$ & 2.50 & 21.00 & 180.00 \\
\hline
\end{tabular}

T. occidentalis pumila. Green Globe Arborvitae. 3-4 ft. Very dense, compact form with dark green foliage.

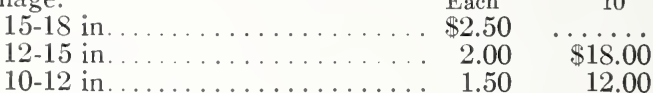

Thuja occidentalis pyramidalis. American Pyramidal Arborvitae. $20-30 \mathrm{ft}$. Slender, columnar growth of bright, rich green hues. Unsurpassed for formal plantings. $\quad$ Each $\quad 10 \quad 100$ $7-8 \mathrm{ft} \ldots \ldots \ldots \ldots \ldots 13.00 \quad \$ 126.00 \quad \$ 1200.00$

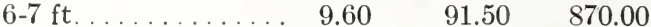
$5-6 \mathrm{ft} \ldots \ldots \ldots \ldots . \ldots . \ldots 00$ $41 / 2-5 \mathrm{ft} \ldots \ldots \ldots \ldots \ldots . \ldots .50 \quad 50.00 \quad 550.00$ $4-4 \frac{1}{2} \mathrm{ft} \ldots \ldots \ldots \ldots \ldots .4 .50 \quad 40.00 \quad 360.00$

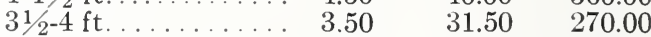
$3-31 / \%$ ft......... $2.85 \quad 24.00 \quad 210.00$ $21 / 2-3 \mathrm{ft} \ldots \ldots \ldots \ldots \ldots 2.25 \quad 20.00 \quad 165.00$

T. occidentalis reidi. Reid Arborvitae. 6-8 ft. Bushy form with short leaves.

\begin{tabular}{lrrr} 
& Each & \multicolumn{1}{c}{10} & 100 \\
$31 / 2-4 \mathrm{ft} . \ldots \ldots \ldots \ldots$ & $\$ \ldots .00$ & $\$ 84.00$ & $\ldots \ldots \ldots$ \\
$3-31 / 2 \mathrm{ft} . \ldots \ldots \ldots$ & 6.50 & 60.00 & $\ldots \ldots \ldots$ \\
$21 / 2-3 \mathrm{ft} . \ldots \ldots \ldots$ & 5.50 & 50.00 & $\$ 480.00$
\end{tabular}

T. occidentalis rosenthali. Rosenthal Arborvitae. 8-10 ft. Noted for its fine columnar form and deep green color. Very fine.

\begin{tabular}{|c|c|c|c|}
\hline 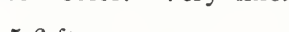 & Each & 10 & 100 \\
\hline $5-$ & $\$ 12.00$ & $\$ 117.00$ & \\
\hline & 9.00 & 87.00 & $\$ 840.00$ \\
\hline $31 / 2-4 \mathrm{ft}$ & 7.50 & 72.00 & 675.00 \\
\hline $3-31 / 2 \mathrm{ft}$. & 6.00 & 55.50 & 510.00 \\
\hline $21 / 2-3$ & 4.00 & 36.00 & 330.00 \\
\hline $2-21 / 2 \mathrm{ft} \ldots \ldots$ & 3.50 & 30.00 & 270.00 \\
\hline
\end{tabular}

T. occidentalis vervaeneana. Vervaene Arborvitae. 8-12 ft. (S). Pyramidal habit with rich bronze color in Winter. Each $10 \quad 100$

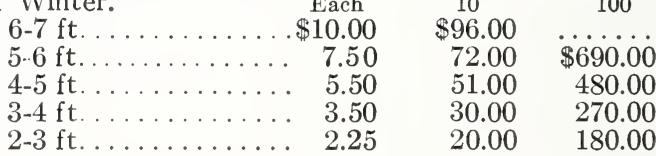

T. occidentalis wareana. Ware Arborvitae, Siberian. 10-12 ft. (S). A very desirable broadly pyramida variety, with shiny blue-green foliage. Excellent

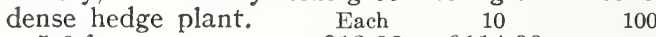

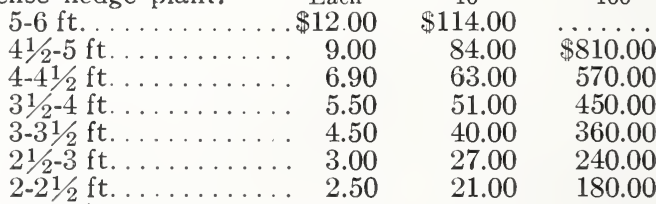

$2-21 / \mathrm{ft} \ldots \ldots \ldots \ldots \ldots 2.50 \quad 21.00 \quad 180.00$

$18-24$ in. . . . . .... $1.80 \quad 15.00 \quad 120.00$

T. occidentalis woodwardi. Woodward Arborvitae. 5-6 ft. Outstandingly satisfactory. A perfect globe type which requires no shearing.

\begin{tabular}{|c|c|c|c|}
\hline & Each & 10 & 100 \\
\hline $21 / 2-3 \mathrm{ft}$ & $\$ 3.50$ & $\$ 30.00$ & $\$ 270.00$ \\
\hline $2-21 / 2 \mathrm{ft}$. & 2.50 & 21.00 & 165.00 \\
\hline 4 in. & 1.75 & 15.00 & 120.00 \\
\hline 8 in. & 1.50 & 12.00 & 90.00 \\
\hline $2-15$ in. . & 1.20 & 9.60 & 75.00 \\
\hline
\end{tabular}


TSUGA canadensis. Canada Hemlock. 70-90 ft. Handsome, graceful tree which nay be used as a specimen or for a hedge.

\begin{tabular}{|c|c|c|c|}
\hline & $\begin{array}{c}\text { Each } \\
\$ 1+00\end{array}$ & 10 & $\begin{array}{c}100 \\
\$ 130000\end{array}$ \\
\hline & 10.00 & 95.00 & 900.00 \\
\hline & 7.50 & 72.00 & 687.00 \\
\hline $\mathrm{ft}$. & 5.50 & 50.00 & 477.00 \\
\hline & 4.50 & 41.50 & 375.00 \\
\hline $3 \mathrm{ft}$. & 3.50 & 31.50 & 279.00 \\
\hline 6 & 2.50 & $21.0 ?$ & $1 \varsigma 0.00$ \\
\hline
\end{tabular}

T. caroliniana. Carolina Hemlock. 50-60 ft. Dark, dense, tufted foliage, sweeping gracefully to the ground. Tall and hardy. Each

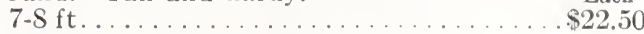
$6-7 \mathrm{ft} \ldots \ldots$ $5-6 \mathrm{ft} \ldots \ldots \ldots \ldots \ldots \ldots \ldots \ldots \ldots \ldots \ldots . \ldots \ldots$

T. sieboldi. Siebold Hemlock. 3-t ft. Desirable for lawn or foundation planting. Slender, spreading branches, with beautiful glossy green foliage. Each

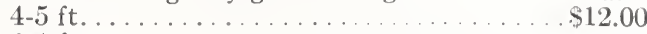
$3-4 \mathrm{ft}$.

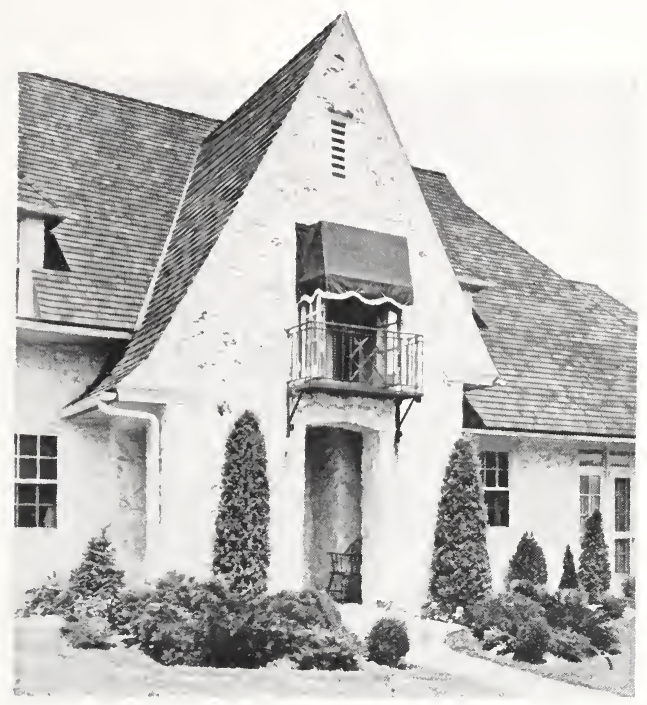

\section{Dwarf Evergreens for Foundation Planting}

Y planting about the entrance of a home can compete with one of Evergreens. Shrubbery is effective and of great beauty during the Spring and Summer, but with the coming of Fall, the forlorn appearance of "gone by" comes and stays for six months.

There are low growing types of Evergreens, many of which retain their dwarf form for a decade or longer. They are to be chosen, for a growth of plant material which barricades the windows, shutting out air and sunshine, is very undesirable.

Plants should be placed not nearer than two feet from the wall, and a space of at least three feet apart, for a crowded plant turns brown. The taller plants are more effective in the background, with the low bushy ones in front. The taller growing ones may be used to advantage, too, as accent points.

Even dwarf varieties need pruning in June of every year. That month is the best, for the new growth has been made, and enough growth will take place after the pruning to obviate the unnatural sheared appearance.

Ordinarily, Evergreens need no watering after they are well established. If a continued drought should occur, a thorough soaking once in seven to ten days is necessary.

The following Evergreens are suggested as suitable for use in Foundation Plantings:

Chamaecyparis obtusa gracilis

Chamaecyparis obtusa nana

Chamaecyparis pisifera filifera

Chamaecyparis pisifera filifera aurea

Chamaecyparis pisifera plumosa

Chamaecyparis pisifera plumosa argentea

Chamaecyparis pisifera plumosa aurea

Chamaecyparis pisifera squarrosa

Juniperus japonica albovariegata

Juniperus japonica pfitzeriana

Juniperus communis aurea

Juniperus communis hibernica

Juniperus communis suecica compacta
Juniperus excelsa stricta

Juniperus horizontalis douglasi

Juniperus sabina

Picea glauca conica

Pinus cembra

Pinus montana mughus

Taxus cuspidata

Taxus cuspidata nana

Thuja occidentalis

Thuja occidentalis douglasi

Thuja occidentalis ellwangeriana

Thuja occidentalis filiformis

Thuja occidentalis globosa

Thuja occidentalis hoveyi

Thuja occidentalis lutea

Thuja occidentalis pyramidalis
Thuja occidentalis reidi

Thuja occidentalis rosenthali

Thuja occidentalis vervaeneana

Thuja occidentalis wareana

Thuja occidentalis woodwardi

Tsuga canadensis

Tsuga caroliniana

Tsuga sieboldi

Ilex glabra

Kalmia latifolia

Leucothoe catesbaei

Pieris floribunda

Rhododendron Hybrids

Rhododendron carolinian um

Rhododendron catawbiense

Rhododendron maximum 


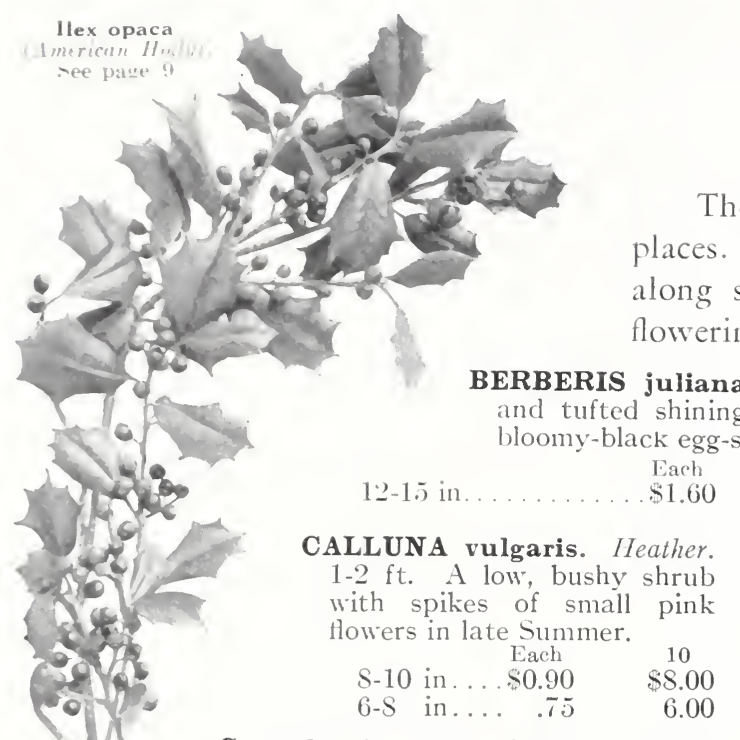

C. vulgaris alba. White Heather. $12-15 \mathrm{in}$. Same as above, except the flowers are white.

$$
\begin{aligned}
& \checkmark-10 \text { in } \ldots \ldots \ldots \ldots \ldots \$ 0.90 \quad \$ 8.00 \\
& 6-5 \text { in } \\
& .75 \\
& 6.00
\end{aligned}
$$

C. vulgaris a urea. Golden Heather. 12-15 in. Very similar in habit to common Heather. Golden tinged foliage.

$$
6-\$ \text { in } \ldots \ldots \ldots \ldots \ldots \ldots . \ldots \ldots .75 \quad \begin{aligned}
& \text { Each } \\
& \$ 6.00
\end{aligned}
$$

C. vulgaris compacta. Compact Heather. 4-6 in. (R) Late mosslike pale lavender flowers.

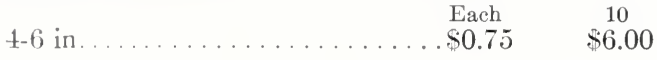

C. vulgaris cuprea. Bronze Heather. (R) 12-15 in. Intense copper color in midseason. Foliage bright yellow green, turning red.

$$
\begin{aligned}
& 6-8 \text { in. } \\
& \text { Each } \\
& \$ 0.75 \\
& 10
\end{aligned}
$$

\section{Evergreen Shrubs}

These broadleaved Evergreens grow best in shady Besides being of value as foundation plants, reams and under trees, some have delightful habits.

. Wintergreen Barberry. 6-8 ft. Has rigid branches green leathery leaves, clustered yellow flowers, and

$9-12$ in.

Each

EUON YMUS radicans. Wintercreeper. A low procum-

\begin{tabular}{|c|c|c|c|}
\hline & Each & 10 & 100 \\
\hline $4 \mathrm{yrs}$ & $\$ 0.75$ & $\$ 6.00$ & $\$ 48.00$ \\
\hline 3 yrs. & .60 & 4.80 & 36.00 \\
\hline$\ldots \ldots \ldots$ & .45 & 3.60 & 27.00 \\
\hline
\end{tabular}
bent shrub with small dull green leaves. Will climb a wall or up the side of a house.

\begin{tabular}{lrrr}
5 yrs $\ldots \ldots \ldots \ldots \ldots \ldots$ & $\$ 1.25$ & $\$ 11.00$ & \multicolumn{1}{c}{$\begin{array}{l}100 \\
\text { Each }\end{array}$} \\
4 yrs $\ldots \ldots \ldots \ldots \ldots \ldots$ & .90 & 7.50 & 60.00 \\
3 yrs $\ldots \ldots \ldots \ldots \ldots \ldots$ & .75 & 6.00 & 45.00 \\
2 yrs $\ldots \ldots \ldots \ldots \ldots \ldots$ & .50 & 4.50 & 39.00
\end{tabular}

E. radicans carrieri. Glossy Wintercreeper. Sturdy, large-leaved variety that readily climbs trees or walls. Forms an attractive hedge when trimmed.

\begin{tabular}{rrrr}
5 yrs $\ldots \ldots \ldots \ldots \ldots \ldots$ & $\$ 1.20$ & $\$ 10$ & \multicolumn{1}{c}{100} \\
4 yrs $\ldots \ldots \ldots \ldots \ldots \ldots$ & .90 & 7.50 & $\$ 90.00$ \\
3 yrs $\ldots \ldots \ldots \ldots \ldots \ldots$ & .75 & 6.00 & 45.00 \\
2 yrs $\ldots \ldots \ldots \ldots \ldots \ldots$ & .50 & 4.00 & 36.00
\end{tabular}

E. radicans colorata. Bronze Wintercreeper. Charming bronze foliage in Winter. A rapid grower; fine for covering banks.

E. radicans minimus. Baby Wintercreeper. Similar to radicans, except leaves are smaller and growth shorter.
3 yrs.
Each
2 yrs
$\$ 7.50$

DAPHNE cneorum. Rose Daphne. (R) 15$18^{\prime}$ in. A dwarf evergreen shrub, with fragrant rich pink blossoms in May and August.

\begin{tabular}{rrrr} 
& Each & \multicolumn{1}{c}{10} & \multicolumn{1}{c}{100} \\
$10-12$ in $\ldots \ldots$ & $\$ 1.75$ & $\$ 15.00$ & $\$ 135.00$ \\
$\$-10$ in . . . & 1.25 & 10.50 & 90.00 \\
$6-8$ in $\ldots \ldots$ & .75 & 6.00 & 54.00
\end{tabular}

ERICA carnea. Flesh Heather. i(R) 6-8 in. Rosy pink, bell-shaped flowers in April and May

$6-8$ in. .......... $\$ 0.60 \quad \$ 5.00$

E. stricta. Corsican IIeath. (R) Grows erect to height of about $2 \mathrm{ft}$; covered with rosy purple flowers.

$4-6$ in ..........\$0.75 $\quad \$ 6.00$

E. vagans. Cornish Heath. (R)【12 in. Flowers purplish red in August andSeptember.
4-6 in.
Each
$\$ 6.00$

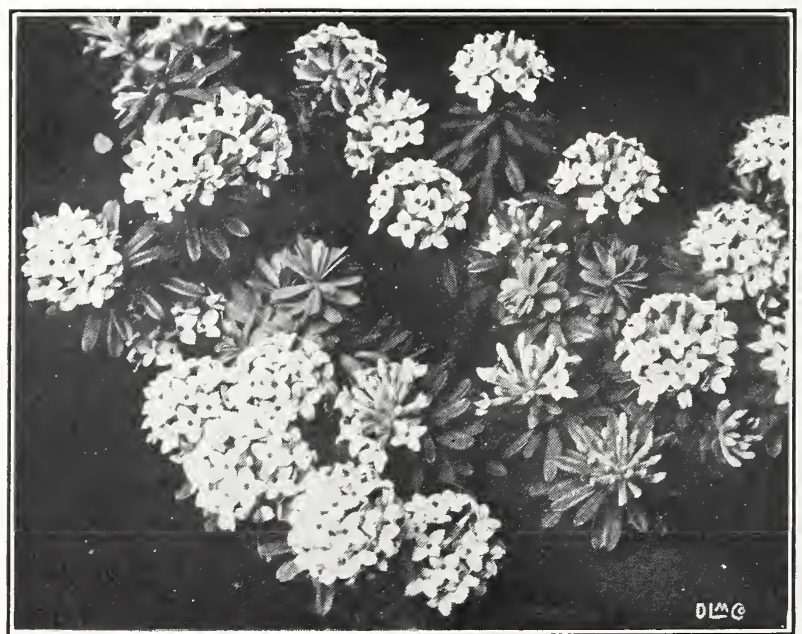

Daphne cneorum (Rose Daphne) 


\section{EUONYMUS-Continued}

E. radicans vegetus. Bigleaf Wintercreeper. As a ground cover, this variety is splendid with its roundish leaves and orange-scarlet berries.

\begin{tabular}{|c|c|c|c|}
\hline 0 & Each & 10 & 100 \\
\hline yrs. & $\$ 2.50$ & $\$ 24.00$ & 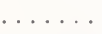 \\
\hline s. & 1.50 & 13.50 & \\
\hline 4 yrs. & 1.20 & 9.00 & $\$ 75.00$ \\
\hline & .90 & 7.50 & 60.00 \\
\hline rs. & .60 & 4.80 & 39.00 \\
\hline
\end{tabular}

ILEX glabra. Inkberry. 5-6 ft. A dense shrub with glossy black berries in dark green, oval foliage. Excellent in shady locations.

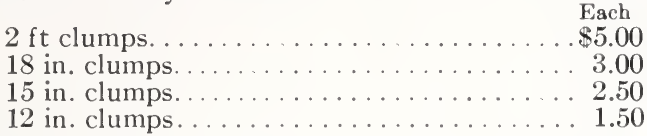

I. opaca. American Holly. 20-30 ft. An increasingly popular slow growing tree, deservedly so, for it is charming with its large, shiny, thorny leaves and red berries.

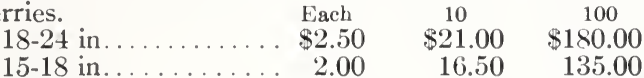

$\begin{array}{llll}15-18 \text { in . . . . . . . } & 2.00 & 16.50 & 135.00 \\ 12-15 \text { in .......... } & 1.50 & 13.50 & 105.00\end{array}$

5 in. pots........ $1.00 \quad 9.00$

KALMIA latifolia. Mountain Laurel. 5-7 ft. Sturdy growth in both its glossy green clustered leaves and profusion of pink and white blossoms.

\begin{tabular}{lrrr} 
& Each & \multicolumn{1}{c}{10} & \multicolumn{1}{c}{100} \\
$31 / 2-4 \mathrm{ft}$. heavy clumps & $\$ 9.00$ & $\$ 85.00$ & $\ldots \ldots .00$ \\
$3-31 / 2 \mathrm{ft}$. heavy clumps & 6.00 & 55.00 & $\$ 510.00$ \\
$21 / 2-3 \mathrm{ft}$. heavy clumps & 4.50 & 42.00 & 384.00 \\
$2-21 / 2 \mathrm{ft}$. heavy clumps & 3.50 & 30.00 & 270.00 \\
$18-24$ in. heavy clumps & 2.50 & 22.50 & 200.00
\end{tabular}

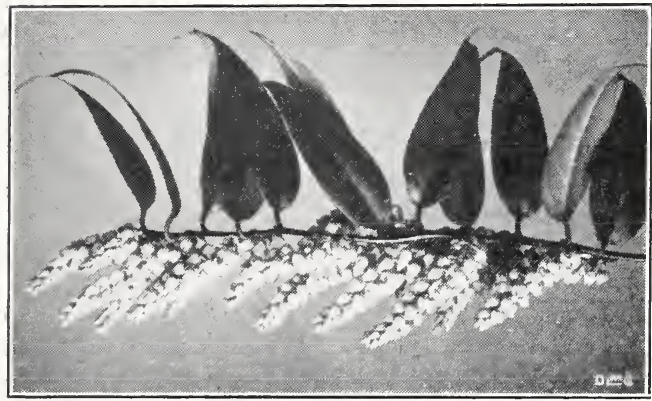

Spray of Leucothoe catesbaei (Drooping Leucothoe)

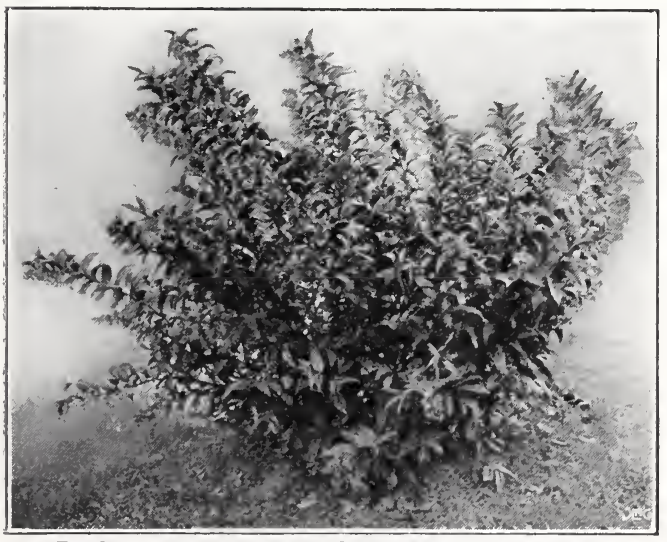

Bush of Leucothoe catesbaei (Drooping Levicothoe)
LEUCOTHOE catesbaei. Drooping Leucothoe, $3-4 \mathrm{ft}$ (R) Graceful, pendulous branches of heavy, shining green foliage; profuse creamy white delicate blossoms in the Spring. Excellent choice for shady location.

\begin{tabular}{|c|c|c|c|}
\hline$x^{2}-50$ & Each & 10 & 100 \\
\hline 2 & $\$ 4.00$ & $\$ 33.00$ & \\
\hline & 3.00 & 27.00 & $\$ 240.00$ \\
\hline & 2.50 & 22.50 & 195.00 \\
\hline 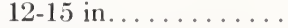 & 2.00 & 18.00 & 150.00 \\
\hline
\end{tabular}

PACHISTIMA canbyi. Canby Pachistima. 8 in. (R) A very low evergreen shrub suitable for rock garden or as a ground cover. Small dark re d flowers. It will make a very beautiful, dense, dark green carpet. Field grown........ $\$ 0.90 \quad \$ 7.80 \quad \$ 66.00$

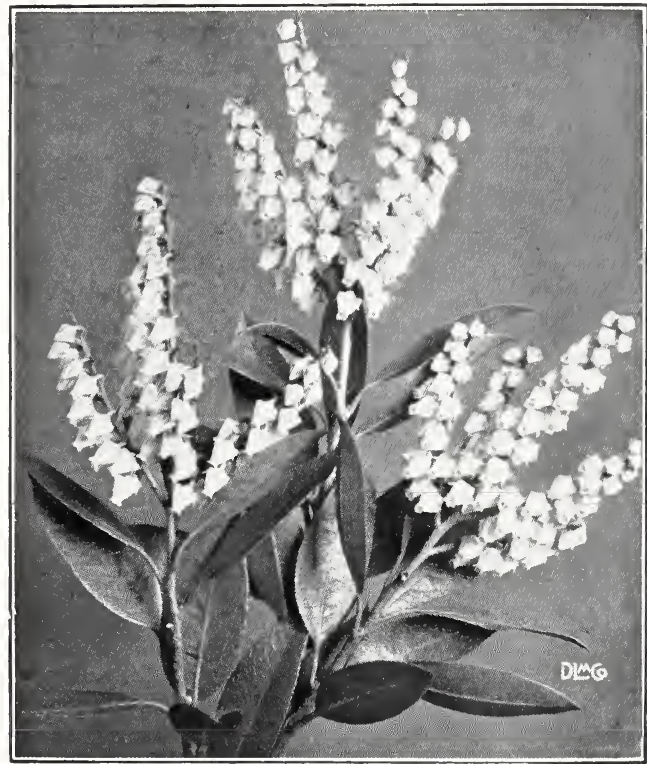

Pieris floribunda (Mountain Andromeda)

PACHYSANDRA terminalis. Japanese Pachysandra. 8-10 in. As a ground covering where grass will not grow, this evergreen is inimitable. In the Spring, nosegays of lovely white blossoms appear through the green.

\begin{tabular}{lrrr} 
& Each & \multicolumn{1}{c}{10} & \multicolumn{1}{c}{100} \\
Field grown . . . . & $\$ 0.35$ & $\$ 2.40$ & $\$ 18.00$ \\
3 in. pots........ & .30 & 2.10 & 15.00
\end{tabular}

PIERIS floribunda. Mountain Andromeda. $3-4 \mathrm{ft}$. (R) Nodding flower clusters in white along a slender stem. Luxuriant small, dark green leaves. IVe recommend it highly.

\begin{tabular}{|c|c|c|c|}
\hline & Each & 10 & 100 \\
\hline $18-24$ in. & $\$ 5.70$ & $\$ 51.00$ & $\$ 474.00$ \\
\hline $15-$ & 3.75 & 33.00 & 300.00 \\
\hline 12 & 3.00 & 27.00 & 240.00 \\
\hline
\end{tabular}

VINCA minor. Common Periwinkle. 4 in. Used as a ground cover in shaded spots. Profuse bright blue petaled flowers in Spring and throughout the Summer and Autumn.

\begin{tabular}{lrrr} 
& Each & \multicolumn{1}{c}{10} & \multicolumn{1}{c}{100} \\
Pot grown.......... & $\$ 0.25$ & $\$ 2.10$ & $\$ 15.00$ \\
Field grown........ & .25 & 2.10 & 15.00
\end{tabular}

v. minor alba. White Common Periwinkle. 4 in. Same as above with white blossoms.

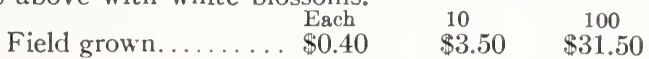




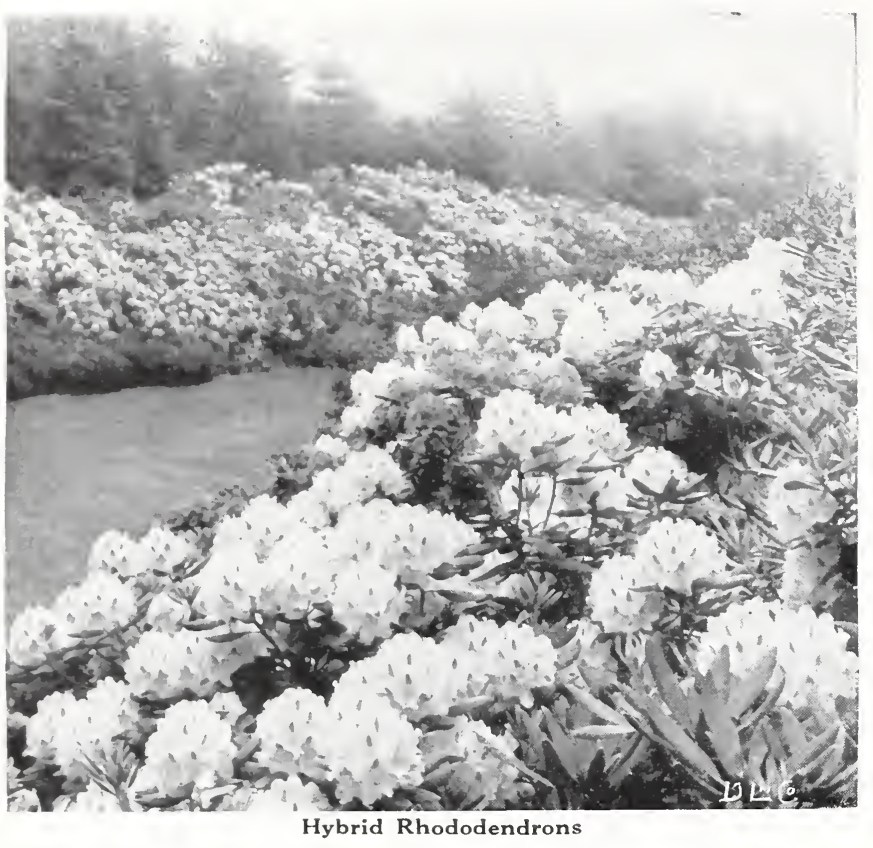

Native Rhododendrons

These are unsurpassed for vigor and hardiness. All are Lursery Grown.

RHODODENDRON carolinianum. Carolina Rhododendron. 4-6 ft. A splendid variety growing to six feet, and profusely covered with pink to deep rose blossoms in May.

\begin{tabular}{|c|c|c|c|}
\hline 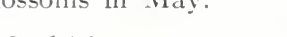 & Each & 10 & 100 \\
\hline $3-31 / 2 \mathrm{ft}$. & $\begin{array}{r}\$ 7.50 \\
600\end{array}$ & $\$ 5.000$ & \\
\hline $\begin{array}{l}21 / 2-3 \mathrm{ft} . \\
2-21 / 2 \mathrm{ft}\end{array}$ & $\begin{array}{l}6.00 \\
4.00\end{array}$ & $\begin{array}{r}\$ 5.00 \\
35.00\end{array}$ & $\$ 300.00$ \\
\hline $18-24$ in. & 2.75 & 25.00 & . \\
\hline $15-18$ in... & 2.00 & 18.00 & \\
\hline $12-15$ in . . . . & 1.75 & 15.00 & . \\
\hline
\end{tabular}

R. catawbiense. Catawba Rhododendron. $6-9 \mathrm{ft}$. Possesses large, round clusters of rosy-lavender flowers in June; rich, dark green leaves.

\begin{tabular}{|c|c|c|c|}
\hline & Each & 10 & 100 \\
\hline & $\$ 4.00$ & $\$ 36.00$ & $\$ 330.00$ \\
\hline Very 1 & 3.5 & 33.00 & 300.00 \\
\hline Very heav & 3.0 & 27.00 & 240.00 \\
\hline Very heavy & 2.50 & 22.50 & 195.00 \\
\hline
\end{tabular}

R. maximum. Rosebay Rhododendron. 8-12 ft. Remarkable for their hardiness. Leaves thick, very large and smooth; flowers white to rose-tinted; blossoms profusely in June and July. This is a handsome specimen plant.

\begin{tabular}{|c|c|c|c|}
\hline 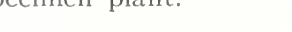 & Each & 10 & 100 \\
\hline $\mathrm{ft}$ & $\$ 5.00$ & $\$ 45.00$ & $\$ 420.00$ \\
\hline & 4.00 & 36.00 & 330.00 \\
\hline & 3.00 & 27.00 & 250.00 \\
\hline 18 & 2.50 & 22.50 & 210.00 \\
\hline n. & 2.00 & 18.00 & 150.00 \\
\hline
\end{tabular}

\section{Collected Rhododendrons}

All of the native Rhododendrons may be collected from their native habitats and sold at reasonable rates in carload lots. These are collected for us by trained collectors, insuring the best of stock.

Write for quotations.

\section{Rhododendrons}

The climax in beauty and sheer loveliness is reached in this family. These broadleaved evergreens have glossy, long, tapering and richly green leaves. Their blossoms are luxuriantly massed in clusters of fresh, delightful colors. Along paths or drives, or as informal plantings for garden or lawn, they give the utmost pleasure.

They ask one thing in return, that they be planted in a decidedly acid soil. We can help you make sure of this.

Hybrid Rhododendrons. Named colors. 3-8 ft. These plants are grown from seeds of Hybrid Rhododendrons. They grow much stronger and bushier than the grafted Hybrids and are perfectly hardy.

Light Rose Deep Pink Purple Orchid Pink Orchid Rose Deep Lavender Old Rose

$18-24$ in Each

$2-21 / 2 \mathrm{ft}$

9.00

Hybrid Rhododendrons. Mixed. $3-8 \mathrm{ft}$. Same as above, only the colors, which shade from red, pink to white, are mixed.

\begin{tabular}{|c|c|c|}
\hline & Each & 10 \\
\hline $21 / 2-3 f$ & $\$ 7.50$ & \\
\hline$-21 / 2 \mathrm{ft}$ & 5.00 & $\$ 48.00$ \\
\hline 4 i & 4.00 & 36.00 \\
\hline $18 \mathrm{in}$ & 3.25 & 30.00 \\
\hline 5 in & 2.75 & 24.00 \\
\hline
\end{tabular}

\section{Dutch Peat}

We recommend the use of Dutch Peat for both Fine and Broadleaved Evergreens.

$\$ 3.00$ per bale; $\$ 2.70$ per bale from 5 to 10 bales.

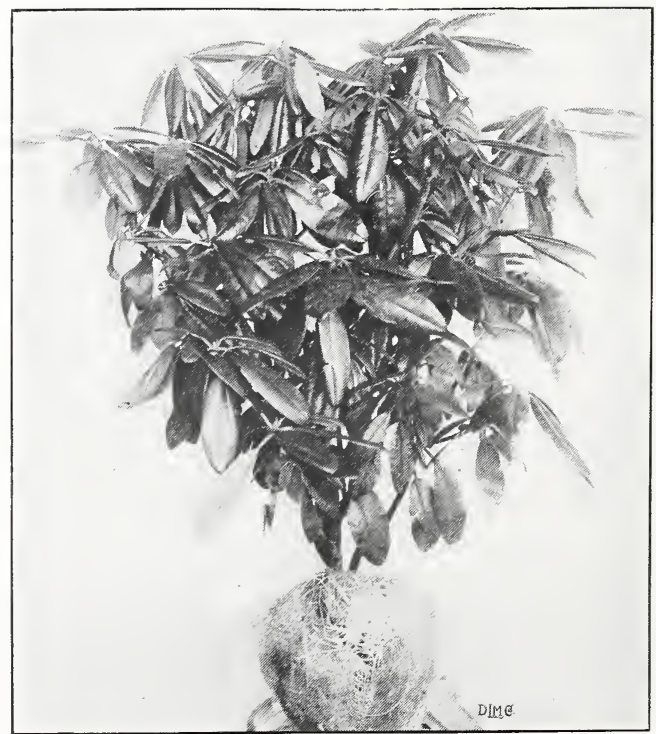




\section{Deciduous Trees}

$\mathrm{D}$ ECIDUOUS TREES can be planted as soon as the frost is out of the ground, and continued until late May, or in the Fall after two or three frosts, until the ground has frozen. In planting Deciduous Trees, dig the hole large enough so that the roots may be laid out straight, and deep enough so the tree will be about 1 inch deeper than it was planted in the nursery, which is shown by the collar on the trunk. While filling in the soil, shake the tree gently up and down and then tramp the earth in firmly. Soak thoroughly. It is advisable to have guy wires on the tree for the first year until the roots become firmly established, as the swaying of the tree may disturb them.

Abbreviations: Suitable for Rock Gardens (R). Suitable for Seashore (S). Attracts Birds (B).

ACER dasycarpum. Silver Maple. 60-80 ft. Tall, luxuriant shade tree. Grows best in moist soil. Brilliant Autumnal coloring.

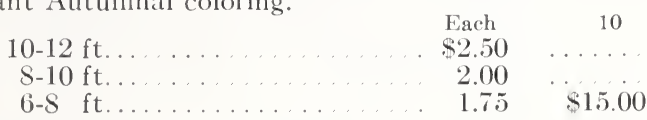

A. dasycarpum wieri. Wier Maple. 60-80 ft. Rapid growth, drooping branches, and delicately cut foliage.

S-10 ft.

Each

$\$ 4.00$

A. plamatum. Japanese Maple. $6-8 \mathrm{ft}$. A handsone shrub of graceful habit. Attractive foliage, especially in Spring and Fall. Suitable for specimen planting.

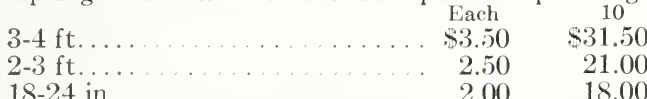

A. plamatum rubrum. Red Japanese Maple. $6-8 \mathrm{ft}$. Delicately cut leaves in rich red tones. Gracefully ornamental. Selected seedlings.

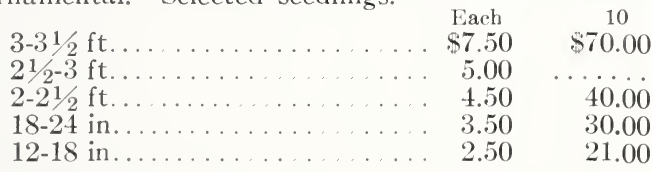

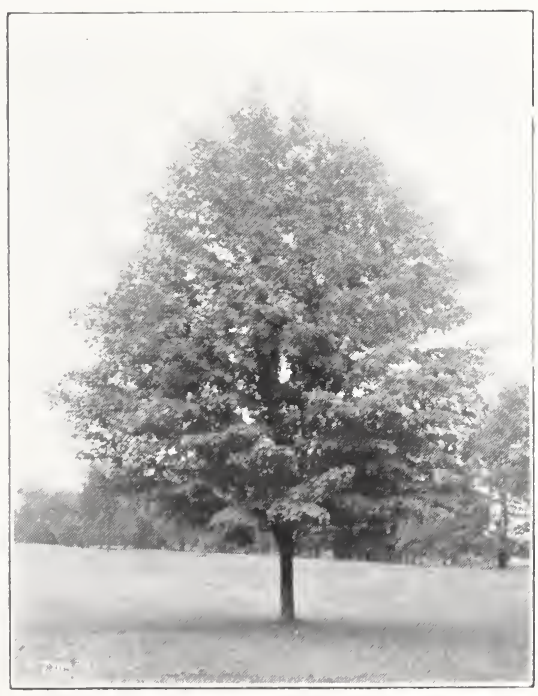

Acer platanoides ( $N$ orway Maple)

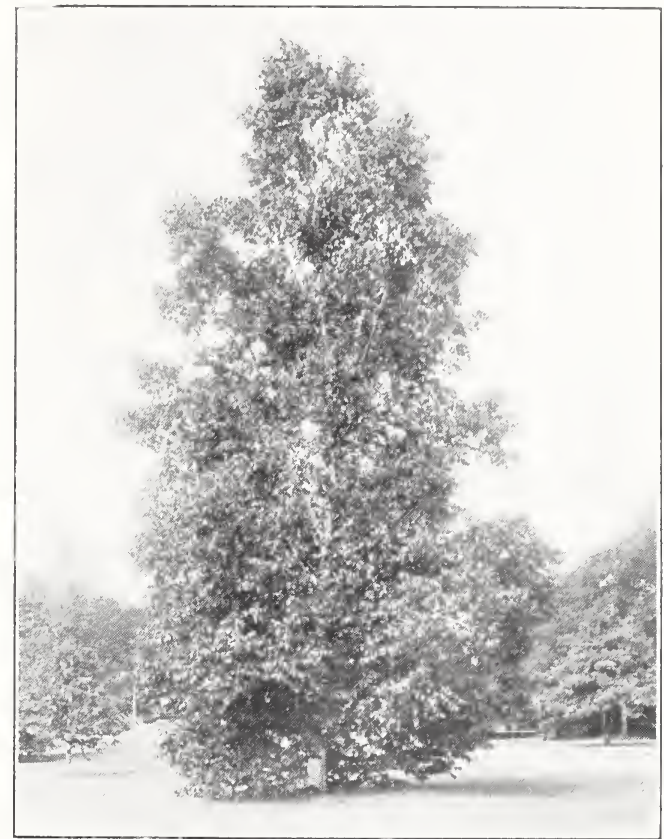

Betula papyrifera (Canoe Birch). See page 12

A. pennsylvanicum. Striped Maple. 20-30 ft. Small, ornamental tree with green and white striped bark.

$6-8 \mathrm{ft}$. . Each

$5-6 \mathrm{ft}$.

$\$ 2.50$ 2.00

A. platanoides. Norway Maple. 50-75 ft. (S) A splendid, heavily foliaged symmetrical tree.

\begin{tabular}{rrrr}
$12-14 \mathrm{ft} \ldots \ldots \ldots \ldots \ldots$ & $\$ 6.50$ & \multicolumn{1}{c}{$\begin{array}{c}\text { Each } \\
10\end{array}$} & \multicolumn{1}{c}{100} \\
$10-12 \mathrm{ft} \ldots \ldots \ldots \ldots$ & 5.00 & $\$ 48.00$ & $\$ 450.00$ \\
$8-10 \mathrm{ft} \ldots \ldots \ldots \ldots$ & 4.00 & 36.00 & 330.00 \\
$6-8 \mathrm{ft} \ldots \ldots \ldots \ldots$ & 2.75 & 24.00 & 210.00
\end{tabular}

A. platanoides schwedleri. Schwedler Maple 10-60 ft. The purple-leaved Norway Maple.

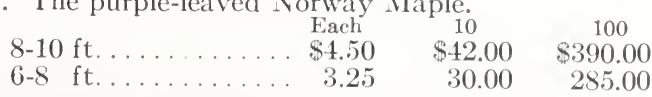

A. rubrum. Red Maple. 50-75 ft. A tall, spreading tree, colorful in the Spring with clusters of reddish flowers, and in the Fall afire with brilliant foliage.

$10-12 \mathrm{ft} \ldots \ldots \ldots \ldots \ldots \ldots \ldots \ldots \ldots \ldots \ldots \ldots \ldots$
$8-10 \mathrm{ft} \ldots \ldots \ldots$

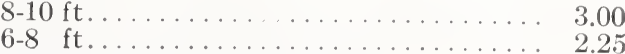

PLANT A TREE THIS YEAR AS A WASHINGTON MEMORIAL. 


\section{ACER-Continued}

A. saccharum. Sugar Maple. 50-75 ft. A thoroughly successful tree anywhere. Broad headed and erect, with silver lining underneath leaves.

\begin{tabular}{|c|c|c|}
\hline.$\$ 20.00 t$ & $\begin{array}{l}\text { Each } \\
\$ 75.00\end{array}$ & 10 \\
\hline cal. & 8.50 & \\
\hline $1 / 2-134$ in. cal. & & \\
\hline$-1 \frac{1}{2} \mathrm{ir}$ & 0 & \\
\hline S-10 ft.. & $\begin{array}{l}3.00 \\
2.00\end{array}$ & \\
\hline
\end{tabular}

BETULA alba. European White Birch. 30-50 ft. Tall, graceful drooping tree, with silver bark.

\begin{tabular}{|c|c|c|c|}
\hline $12-14 \mathrm{ft} .$, & $B \& B$ & $\begin{array}{l}\text { Each } \\
\$ 5.00\end{array}$ & 10 \\
\hline $10-12 \mathrm{ft}$. & $\mathrm{B} \& \mathrm{~B}$. & 3.00 & $\$ 27.00$ \\
\hline $\mathrm{s}-10 \mathrm{ft}$. & B\&B. & 2.50 & 22 . \\
\hline ft., & $B \& B$ & 2.00 & 0 \\
\hline $5-6 \mathrm{ft}$. , & $B \& B$. & 1.50 & 13.50 \\
\hline
\end{tabular}

B. papyrifera. Canoe Birch. 40-50 ft. (S) Large-leaved, hardy. It's white bark makes it particularly effective in group plantings.

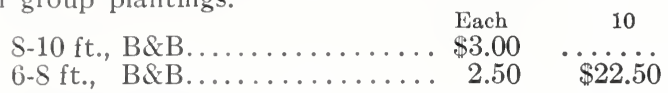

B. pendula gracilis. Cutleaf Weeping Birch. 40-50 ft. Picturesque, long, pendulous branches. Vigorous grower in rich, moist soil.

\begin{tabular}{|c|c|c|}
\hline$[., 1$ & $\begin{array}{l}\text { Each } \\
\$ 6.00\end{array}$ & 0 \\
\hline$\therefore B \& B$ & 5.00 & $\$ 45.00$ \\
\hline B\&B. & 4.00 & 36.00 \\
\hline
\end{tabular}

CATALPA bignonioides nana. Umbrella Catalpa. Luxuriant glossy foliage for formal plantings.

$4 \mathrm{yr}$, heads, $5-6 \mathrm{ft}$. stems....... $\$ 4.00 \quad \$ 35.00$

3 yr. heads, $5-6 \mathrm{ft}$. stems. . . . . . $3.50 \quad 33.00$

2 yr. heads, $5-6 \mathrm{ft}$. stems........ $2.50 \quad 22.50$

C. specisoa. Western Catalpa. 80-100 ft. Large, hardy, rapid grower, with white flowers.

$8-10 \mathrm{ft}$.

Each $\$ 1.00$

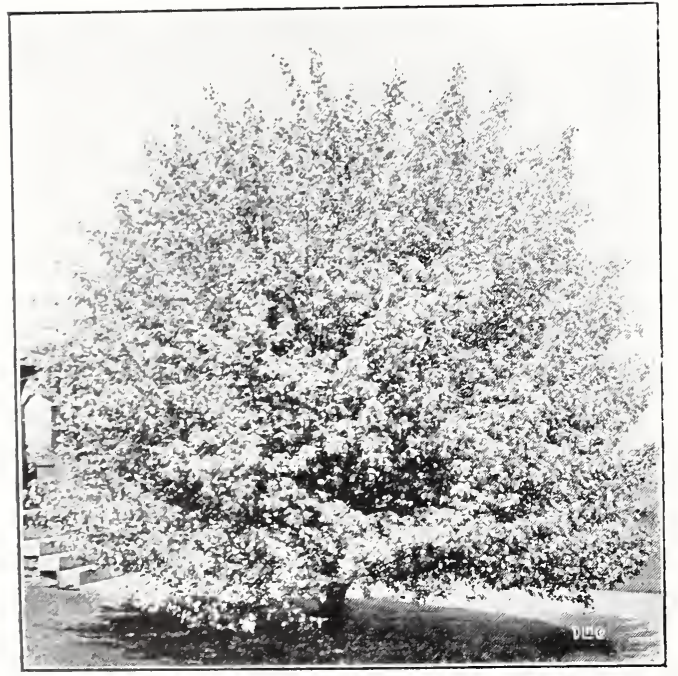

Crataegus coccinea (Thicket Hawthorn)

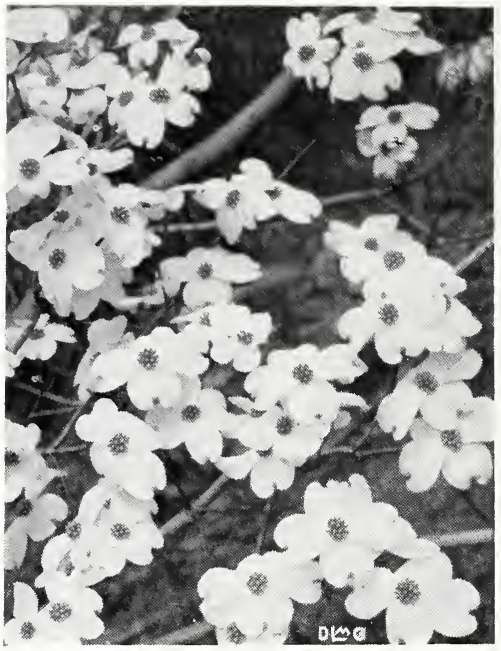

Cornus florida (Flowering Dogwood)

CERCIS canadensis. American Redbud. 12-15 ft. Profuse purplish-red flowers in Spring.

$2-3 \mathrm{ft} . \ldots \ldots \ldots \ldots \ldots \ldots \ldots+\$ 1.00$ $\$ 9.00$

CHIONANTHUS virginica. White Fringe. $15-18 \mathrm{ft}$. Splendid for lawn. White fringy flowers in Spring.

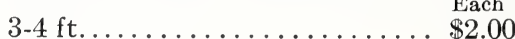

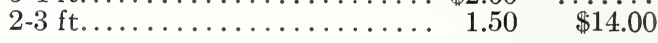

CORNUS florida. Flowering Dogwood. 15-25ft. A beautiful tree at every season. The white flowers appear almost before the leaves, making a mass of bloom.

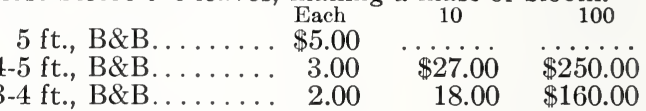

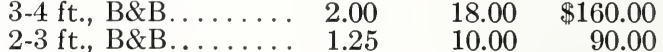

C. florida rubra. Redflowering Dogwood. 15-20 ft. Deep, rose colored flowers; blooms in early Spring like the above.

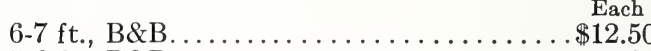

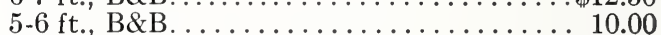

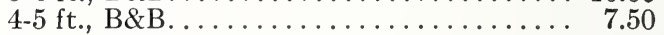

$3-4 \mathrm{ft} .$, B\&B..................... 5.00

CRATAEGUS arnoldiana. Arnold Hawthorn. 15-20 $\mathrm{ft}$. A small tree with spreading and ascending branches. Conspicuous in August and September because of its profusion of bright crimson fruit.

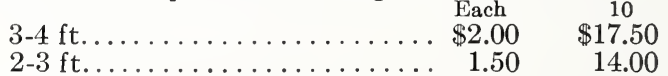

C. coccinea. Thicket Hawthorn. 10-12 ft. (S) Dense, thorny branches, shiny foliage, scarlet berries lasting to New Year.

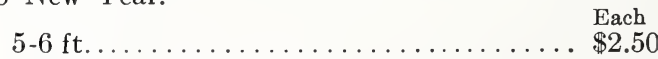

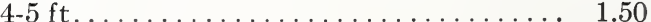

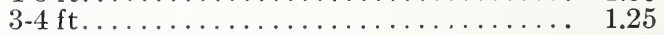

C. coccinioides. Scarlet Hawthorn. 15-25 ft. A densely branched, round-topped tree, radiant in Autumn with bright orange and scarlet foliage and erect clusters of crimson fruit.

$4-5 \mathrm{ft}$.

Each

$3-4 \mathrm{ft}$

$\$ 1.75$

ft. $\ldots \ldots \ldots \ldots \ldots \ldots \ldots$ 


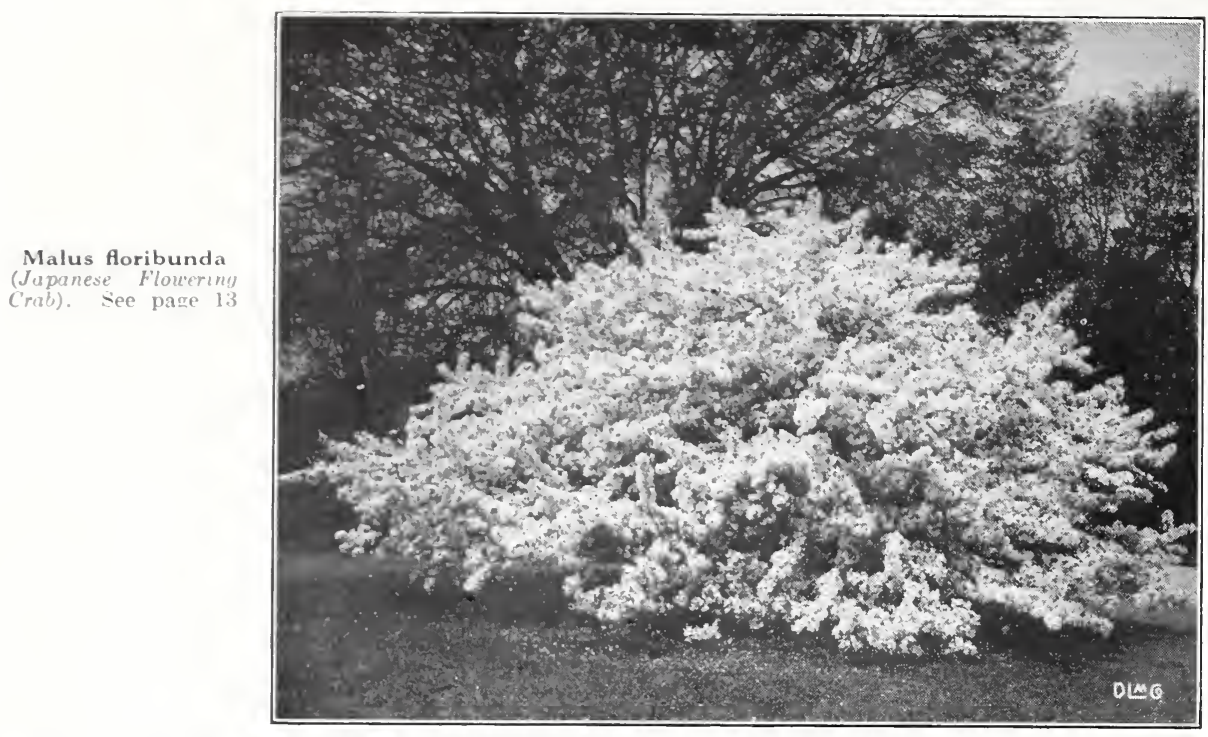

MALUS-Continued

M. niedzwetzkyana. Redvein Crab. 20-25 ft. Larger than most crabs, with deep pink blossoms.

$$
\begin{aligned}
& 5-6 \mathrm{ft} ., \text { B\&B. . . . . . . . . } \$ 3.00 \quad \$ 27.00 \\
& 3-4 \mathrm{ft} ., \mathrm{B} \& \mathrm{~B} \ldots \ldots \ldots \ldots \ldots \ldots . . \ldots 1.50 \quad 12.00
\end{aligned}
$$

M. robusta. Cherry Crab. 15-20 ft. Vigorous tree with white or pale pink blossoms, followed by yellow fruit, crimson touched.

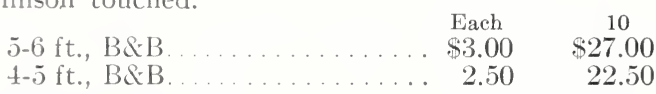

M. robusta, Snow Hill. Snow Hill Crab, 15-20 ft. Similar to robusta except whiter and blooms more freely.

$$
3-4 \mathrm{ft} ., \mathrm{B} \& \mathrm{~B}
$$

M.'sargenti. Sargent Crab. 6-8 ft. A dwarf tree with white blossoms and showy red fruits.

$$
3-4 \mathrm{ft} ., \text { B\&B............. } \$ 33.00 \quad \$ 24.00
$$

\begin{tabular}{|c|c|c|}
\hline & Each & 10 \\
\hline & $\$ 5.00$ & $\$ 45.00$ \\
\hline$=$ & 2.50 & 24.00 \\
\hline B & 2.00 & 17.50 \\
\hline
\end{tabular}

M. scheideckeri. Scheidecker Crab. 12-15 ft. Large, double flowers of light rose color that last a long time.

M. sieboldi. Toringo Crab. Dense, low shrub, late; dark rose colored buds contrasting beautifully with white petals.

$4-5 \mathrm{ft} ., \mathrm{B} \& \mathrm{~B}$

Each

$3-4 \mathrm{ft} ., \mathrm{B} \& \mathrm{~B}$

$\$ 2.50$

2.00

M. spectabilis. Chinese Flowering Crab. 15-18 ft. Small tree with coral-pink buds of unusual loveliness.

$$
\begin{aligned}
& 3-4 \mathrm{ft} ., \\
& 2-3 \mathrm{ft} ., \mathrm{B} \& \mathrm{~B} .
\end{aligned}
$$$$
\text { Each }
$$

M. theifera. Tea Crab. 18-20 ft. One of the most spectacular of flowering Apples; irregular branches covered the entire length with pink blossoms.

$5-6 \mathrm{ft} ., \mathrm{B} \& \mathrm{~B}$

Each

4-5 ft., B\&B
MORUS alba pendula. Teas Weeping Mulberry. 8-10 $\mathrm{ft}$. A splendid small weeping lawn tree, which forms a perfect umbrella-shaped head of light green. Reddish purple fruit.

5 yr. head

2 yr. head.

$\$ 6.00$

2.50

M. alba tatarica. Russian Mulberry. (B) A low, bushy topped tree with reddish fruit. Hardy and desirable. Attractive to birds.

$10-12 \mathrm{ft}$

Each

$8-10 \mathrm{ft}$

PLATANUS occidentalis. American Planetree. 130$170 \mathrm{ft}$. Often called Sycamore or Buttonwood. A massively foliaged, large tree with heart-shaped leaves and picturesquely shaded gray and white bark. Unquestionably a success.

$10-12 \mathrm{ft}$

Fach

$8-10 \mathrm{ft}$

$\$ 3.00$

2.25

POPULUS candicans. Balm-of-Gilead Poplar. A big, spreading tree; also fast growing, whose buds have pleasant resinous fragrance in Spring.

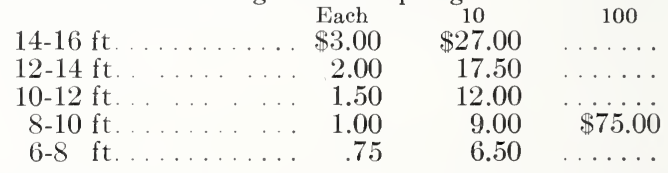

P. eugenei. Carolina Poplar. A shade tree which grows rapidly in any soil. Attractive, with heart-

\begin{tabular}{|c|c|c|c|}
\hline & $\begin{array}{l}\text { Each } \\
\$ 1.50\end{array}$ & $\begin{array}{c}10 \\
\$ 12.00\end{array}$ & $\begin{array}{c}100 \\
\$ 90.00\end{array}$ \\
\hline 8 & 1.00 & 9.00 & \\
\hline & .90 & 7.50 & 60.0 \\
\hline
\end{tabular}
shaped foliage and gray-green bark.

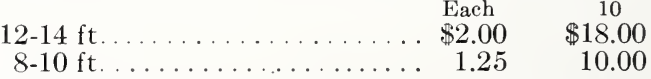

P. nigra italica. Lombardy Poplar. 60-80 ft. Exceedingly popular for screening and formal ornamental effects because of its columnar form. 
PRUNUS armeniaca. Common A pricot. $8-15 \mathrm{ft}$. A handsome and ornamental tree. Very hardy for New England gardens.

$5-6 \mathrm{ft}$.

Each

cerasifera othello. Improved Purpleleaf Plum. Keeps its rich bronze-purple hue throughout the season. Wine-red fruit.

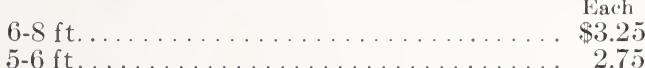

P. cerasifera pissardi. Purpleleaf Plum. 12-15 ft. A small tree with pinkish-white flowers and lustrous dark purple leaves.

\begin{tabular}{lrrr}
$6-8 \mathrm{ft} . \ldots \ldots \ldots \ldots \ldots$ & \multicolumn{1}{c}{$\begin{array}{c}\text { Each } \\
\$ 3.00\end{array}$} & \multicolumn{1}{c}{10} & \multicolumn{1}{c}{100} \\
$5-6 \mathrm{ft} \ldots \ldots \ldots \ldots \ldots$ & 2.75 & $\$ 25.00$ & $\ldots \ldots \ldots$ \\
$4-5 \mathrm{ft} \ldots \ldots \ldots \ldots \ldots$ & 2.00 & 18.00 & $\$ 150.00$ \\
$3-4 \mathrm{ft} \ldots \ldots \ldots \ldots \ldots \ldots$ & 1.50 & 12.50 & 105.00
\end{tabular}

P. incisa. Japanese Cherry. Has ascending and spreading branches with twiggy branchlets, bearing pale pink to pure white flowers. Fine lawn specimen.

$3-1 \mathrm{ft}$.

Each

.' sargenti. Sargent's Japanese Cherry. $40-50 \mathrm{ft}$. A handsome type with double pink to rose colored flowers. The young unfolding leaves are ruddy brown. This is a long-lived variety.

$3-1 \mathrm{ft} \ldots \ldots \ldots \ldots \ldots \ldots \ldots \ldots \ldots \ldots \ldots \ldots$

P. subhirtella. Higan Cherry. The first to open its blossoms. They are silvery pink and completely hide the twiggy branchlets on this bushlike variety.

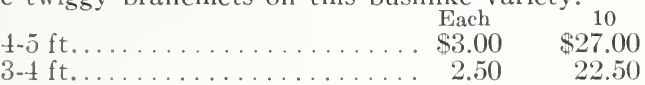

\section{JAPANESE FLOWERING CHERRIES}

A choice assortment noted for their showy, luxuriant blossoms in early Spring.

Beni Higan. Single blush pink.

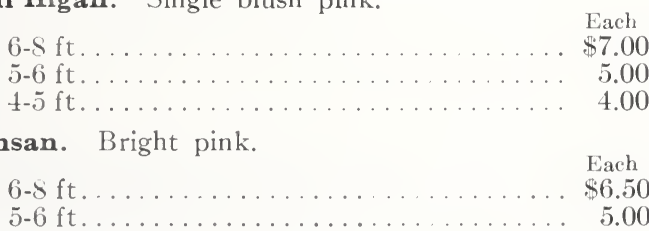

Kofugen. Buds crimson, blossoms old rose. $25-30 \mathrm{ft}$

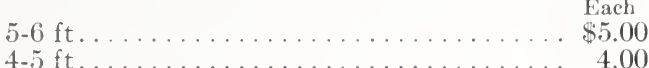

Naden. Lovely double pink. $1 \tilde{\jmath}-20 \mathrm{ft}$

$6-8 \mathrm{ft} \ldots \ldots \ldots \ldots \ldots \ldots \ldots \ldots \ldots \ldots \ldots+\ldots . \ldots \ldots$

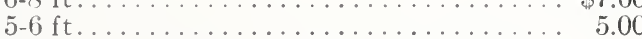

Yoshino. Buds red, blossoms single white.

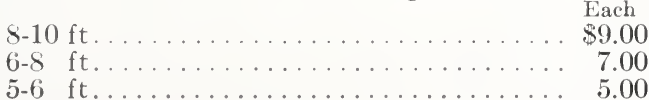

Prunus fruticosa pendula. Weeping Cherry. Charming pendulant branches, clustered with light pink blossoms. An ornamental asset.

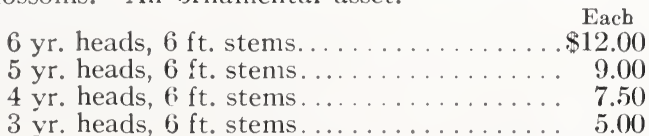

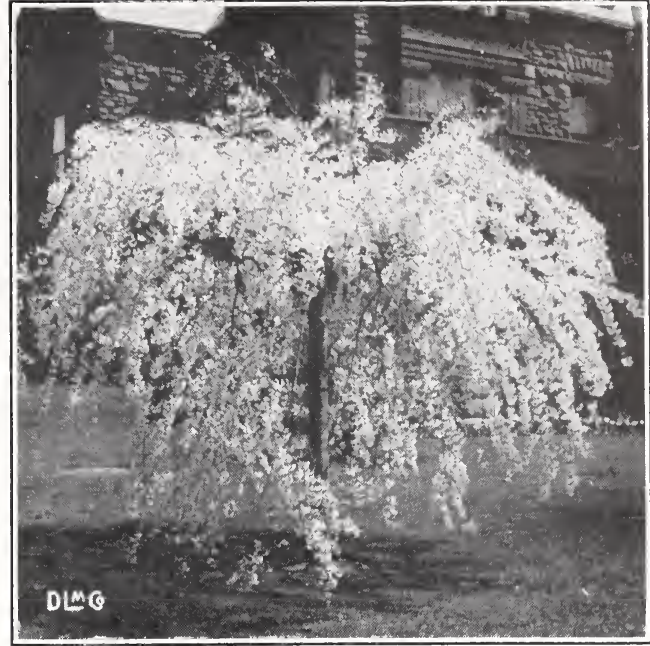

Prunus fruticosa pendula (Weeping Cherry)

Pyrus calleryana. Chinese Pear. 25-30 ft. Flowers little pinkish in bud, turning to white as they fully open. Flowers in early April, and is first Pyrus to blossom.
$5-6 \mathrm{ft}$.
Each 10
$4-5 \mathrm{ft}$
$\$ 3.50$
$\$ 30.00$
25.00

QUERCUS palustris. Pin Oak. 75-90 ft. Has deeply cut leaves, highly colored in Fall.

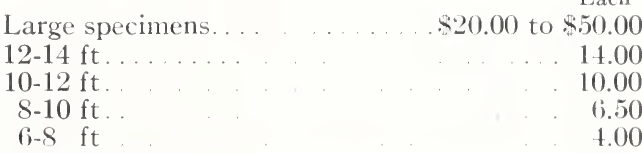

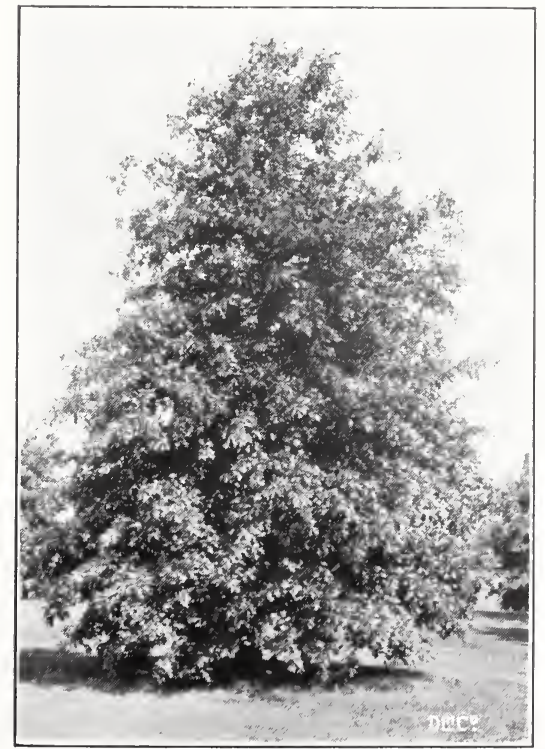

Quercus palustris ( $P$ in $\mathrm{Oak}$ )

PLANT A TREE THIS YEAR AS A WASHINGTON MEMORIAL. 
SALIX blanda. Wisconsin Weeping Willow. 50-60 ft. The hardiest of this group. Valuable because of its resistance to severe cold. Each 10
$10-12 \mathrm{ft}$
$\$ 3.00$
$+5 \mathrm{ft}$
.75
$\$ 6.00$

S. pentranda. Laurel Willow. 15-20 ft. (S) Highly recommended for either tall hedge or as single speci-
men. Dark glossy leaves.
$12-14 \mathrm{ft}$
$10-12 \mathrm{ft}$
$\begin{array}{lc}\text { Each } & 10 \\ \$ 3.00 & \$ 27.50\end{array}$
$2.25 \quad 21.00$

S. vitellina. Golden Willow. $70-\mathrm{s} 0 \mathrm{ft}$. (S) A large tree of great dignity, with bark of decided yellowish hue in Winter.

Each

$10-12 \mathrm{ft}$

SORBUS aucuparia. European Mountain Ash. 25-30 $\mathrm{ft}$. Clusters of orange-scarlet fruit make this a most ornamental small lawn tree.

\begin{tabular}{|c|c|c|c|}
\hline 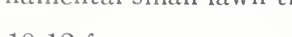 & Each & 10 & 100 \\
\hline $10-12 \mathrm{ft}$ & $\$ 2.75$ & & ... \\
\hline$-10 \mathrm{ft}$. & 2.25 & $\$ 20.00$ & \\
\hline $6-\mathrm{s} \mathrm{ft}$ & 1.75 & 15.00 & $\$ 135.00$ \\
\hline $5-6 \mathrm{ft}$ & 1.25 & 10.50 & 75.00 \\
\hline
\end{tabular}

TILIA cordata. Littleleaf European Linden. 90-100 ft. Vigorous, handsome tree.

Each $6-8 \mathrm{ft}$.

$\$ 3.00$

T. platyphyllos. Bigleaf European Linden. 100-120 ft. Either one of these Lindens has unusual dignity.

$6-8 \mathrm{ft} \ldots \ldots \ldots \ldots \ldots \ldots \ldots \ldots \ldots \$ \ldots 2.00$

ULMUS americana. American Elm. 100-120 ft. Deservedly one of America's foremost trees; vaulted cathedral effect and simple grace. Each

$12-14 \mathrm{ft} \ldots \ldots \ldots \ldots \ldots \ldots \ldots \ldots \ldots \ldots$

$10-12 \mathrm{ft} \ldots \ldots \ldots \ldots \ldots \ldots \ldots \ldots \ldots \ldots \ldots . \ldots \ldots \ldots$

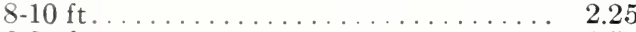

$6-8 \mathrm{ft} \ldots \ldots \ldots \ldots \ldots \ldots \ldots \ldots \ldots \ldots \ldots . . .50$

U. americana (vase-shaped). Vase-shaped American Elm. $125-150 \mathrm{ft}$. Of unusual symmetry. Each

$12-14 \mathrm{ft} \ldots \ldots \ldots \ldots \ldots \ldots \ldots \ldots \ldots \ldots . \ldots \ldots$

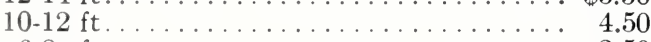

$6-8 \mathrm{ft} \ldots \ldots \ldots \ldots \ldots \ldots \ldots \ldots \ldots . \ldots 2.50$

U. glabra camperdowni. Camperdown Elm. Vigorous, irregular branches, with uniform weeping head. This type is uncommon and of great charm. Each

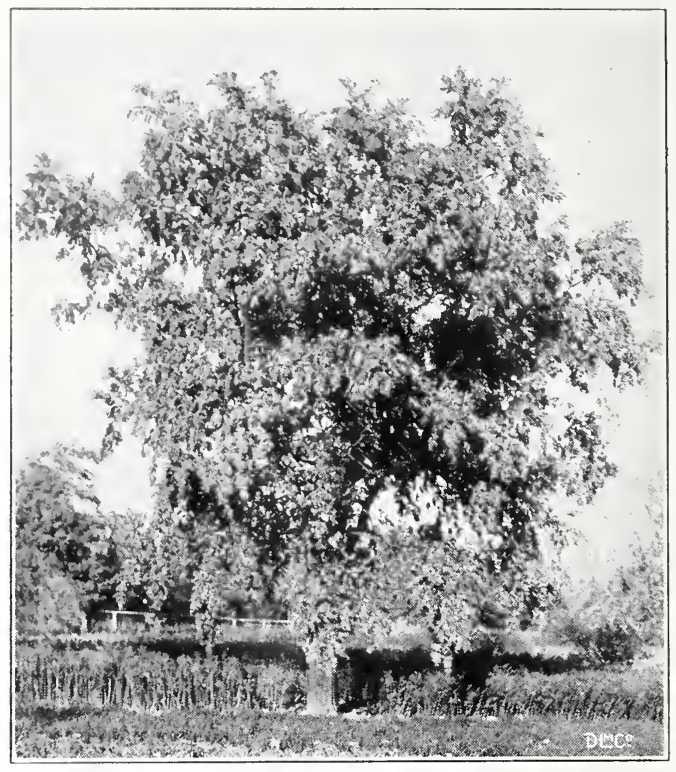

Ulmus pumila (Asiatic Elm)

U. moline. Moline Elm. 75-85 ft. A distinctive new variety, with nearly parallel branches pointing upwards, then pendulous. The light green, shiny leaves growing in this fashion give a charming fountain effect.

Each

10

$8-10 \mathrm{ft} \ldots \ldots \ldots \ldots \ldots \ldots \ldots \ldots . \ldots \ldots 30 \ldots \ldots$

$6-8$ ft...............

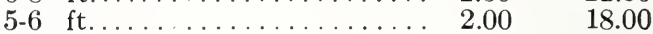

U. pumila. Asiatic Elm . 70-80 ft. Small, slenderly delicate pendulous branches. Exquisite. Grows in poor soil; hardy, and grows very rapidly. Very fine shade tree. Each 10

$8-10 \mathrm{ft} \ldots \ldots \ldots \ldots \ldots \ldots \ldots . \ldots 2.50 \quad \$ 20.00$

$\begin{array}{llll}6-8 \mathrm{ft} \ldots \ldots & \ldots & \ldots & \ldots\end{array}$

$5-6 \mathrm{ft} \ldots \ldots \ldots \ldots \ldots \ldots \ldots \ldots \ldots$

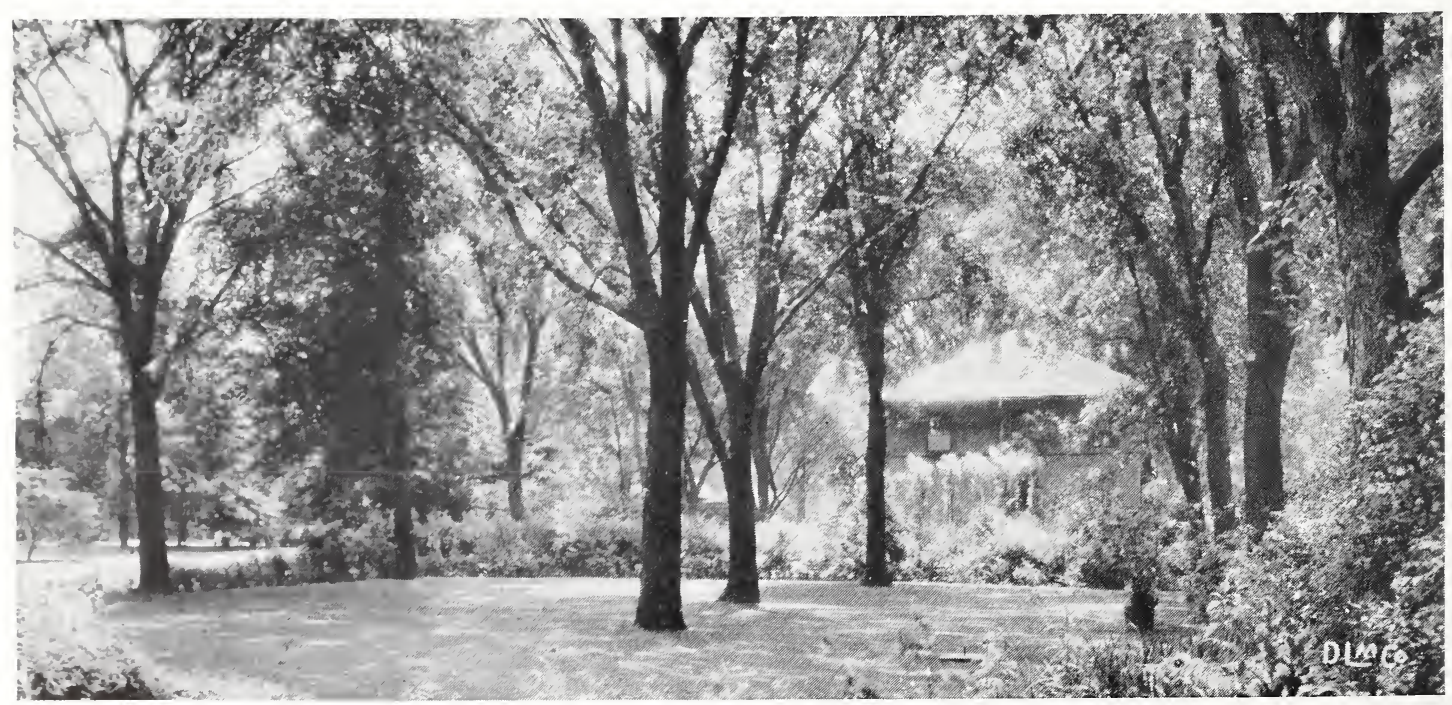

PLANT A TREE THIS YEAR AS A WASHINGTON MEMORIAL. 


\section{Flowering Shrubs}

$\mathrm{T}$

HERE is nothing which gives greater return for money expended than this group. Most shrubs are showered with color - the golden yellow of the Forsythias, purest white of the Spireathe blue of the Syringa-deep red of the Weigelas-or mass of brilliant blooms of the Azaleas. They are invaluable as screens, boundaries, or in foundation plantings, either used alone or with Evergreens.

Shrubs, like deciduous trees, may be planted as soon as the frost is out of the ground until late May, and again in che Fall after two or three frosts, until the ground is frozen.

When Shrubs are received from the nursery they are in a dormant condition. The plant should be placed in the ground immediately, for if the roots dry out it will die.

The hole into which the plant is placed should be wide enough so that the roots lie flat. Fill in the soil, shaking the plant gently up and down to sift the soil around the roots, and firm it thoroughly. After a thorough soaking with water, the Shrub needs no further attention except the general care of fertilizing and pruning each year.

May we give a word of caution about pruning? The best time to prune Shrubs is right after the blooming season. Cut out all dead and old wood. Most shrubs flower on the new growth so this should not be removed.

Lilacs should be pruned only once every six or seven years, and then cut back hard.

Nothing benefits a Shrub more than proper pruning. When done correctly, you will be rewarded with a wealth of blooms.

Abbreviations: Suitable for Rock Gardens (R). Suitable for Seashore (S). Attracts Birds (B).

ACANTHOPANAX pentaphyllum. Fiveleaf Aralia. 7-8 ft. (R) A strong, upright shrub with graceful arching, spiny branches covered with bright, shiny green foliage. Splendid for rockeries, shady places or as a hedge.

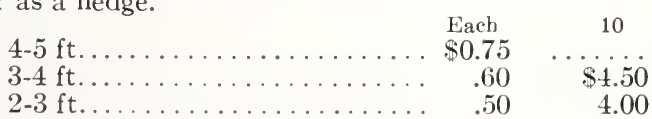

AMELANCHIER canadensis. Downy Shadblow. 12-15 ft. (B-S) A shrubby tree of delicate grace, showered with snowy white blossoms in May.

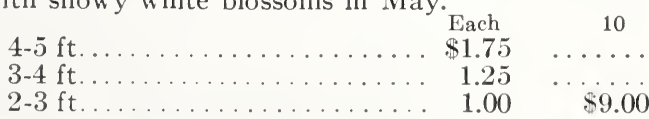

AMORPHA fruticosa. Indigobush. 10-12 ft. Violetpurple flowers makes this an unusual possession, and lacy background for more vivid coloring. Really lovely.

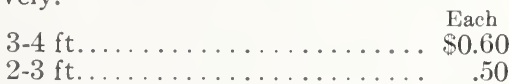

$2-3 \mathrm{ft}$.

.50

ARONIA arbutifolia. Red Chokeberry. 10-12 ft. (B-S) A fine border shrub with bright red berries.

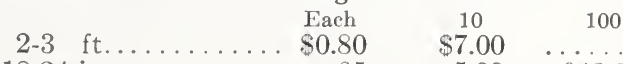

$$
\begin{aligned}
& 18-24 \text { in . . . . . . . .65 } \quad 5.00 \quad \$ 42.00
\end{aligned}
$$

Azaleas will be balled and burlapped (B\&B without extra charge

AZALEA arborescens. Sweet Azalea. $5 \mathrm{ft}$. Was ever a fairer flower made to grace a shady spot? This variety has white flowers and pink stamens.

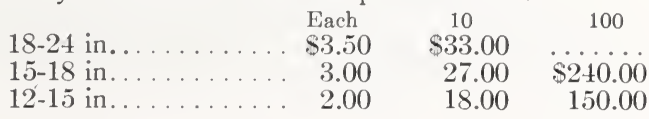

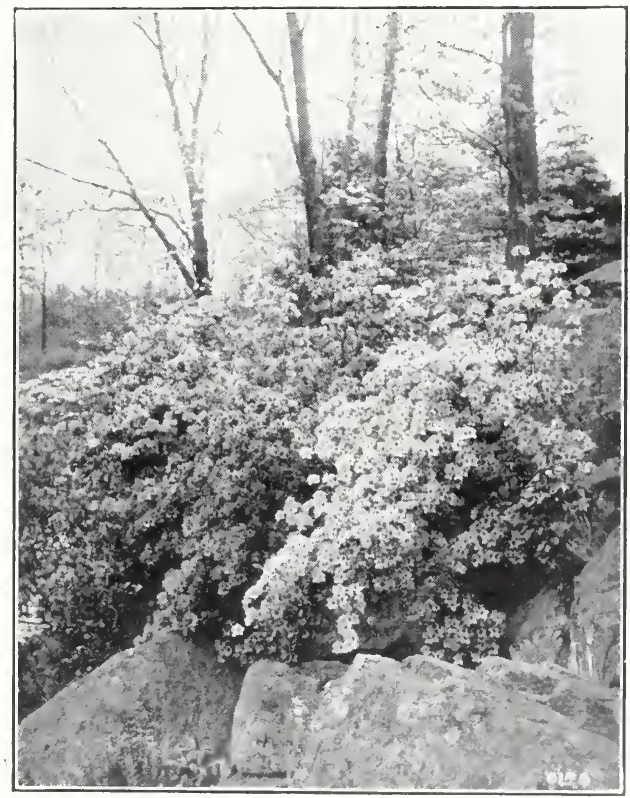

Azalea calendulacea (Flame Azalea)

A. calendulacea. Flame Azalea. $8 \mathrm{ft}$. Brilliant lemonyellow and orange flowers in late May. Mass with evergreens.

\begin{tabular}{rrrr}
$21 / 2-3 \mathrm{ft} \ldots \ldots \ldots \ldots \ldots$ & \multicolumn{1}{c}{$\begin{array}{c}10 \\
\$ 4.50\end{array}$} & $\$ 42.00$ & \multicolumn{1}{c}{100} \\
$2-21 / 2 \mathrm{ft} \ldots \ldots \ldots \ldots$ & 3.50 & 33.00 & $\$ 300.00$ \\
$18-24$ in $\ldots \ldots \ldots \ldots$ & 3.00 & 27.00 & 240.00 \\
$15-18$ in $\ldots \ldots \ldots \ldots$ & 2.00 & 18.00 & 150.00
\end{tabular}


CALLICARPA purpurea. Chinese Beautyberry. $5 \mathrm{ft}$. Pink-tinted blossoms in August, followed by clustered violet-purple berries.

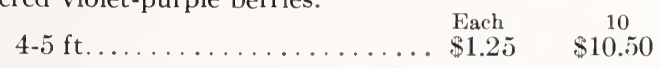

CAL YCANTHUS floridus. Common Sweetshrub. $6 \mathrm{ft}$. Interesting reddish-brown shoots and glossy green leaves. Blooms all Summer.

Each

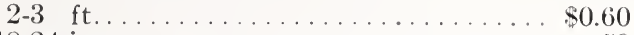

$18-24$ in. .

.50

CLETHRA alnifolia. Summersweet. $6 \mathrm{ft}$. Thrives in damp, shady places which most shrubs cannot endure. A dainty shrub with creamy-white flowers.

$$
\begin{array}{crr}
2-3 \mathrm{ft} \ldots \ldots \ldots \ldots \ldots \ldots \ldots \ldots \ldots & \$ 0.75 & \$ 5.50 \\
18-24 \text { in } \ldots \ldots \ldots \ldots \ldots \ldots \ldots \ldots & .60 & 4.50
\end{array}
$$

CORNUS alba. Tatarian Dogwood. (B-S) $10 \mathrm{ft}$. Redtwigged and therefore most attractive with evergreens in Winter. Small white blossoms in early Summer are in clusters, and nearly flat in appearance.

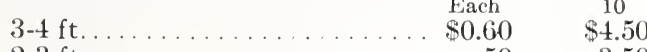

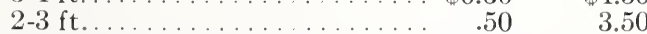

\begin{tabular}{|c|c|}
\hline & \\
\hline & $\begin{array}{l}\text { Each } \\
\$ 1.00\end{array}$ \\
\hline $4-5$ & .75 \\
\hline
\end{tabular}

C. amomum. Silky Dogwood (B) $10 \mathrm{ft}$. Abundance of white flowers in June, and lovely blue berries in October.

C. paniculata. Gray Dogwood. (B-S) $10 \mathrm{ft}$. An outstanding free flowering shrub. White fruit and red stems, showy in the Fall.

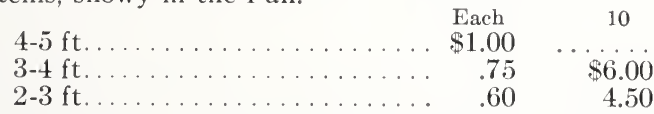

C. stolonifera. Red-osier Dogwood. (B) $8 \mathrm{ft}$. A beautiful type with blood red branches, abundance of blossoms, followed by white berries.

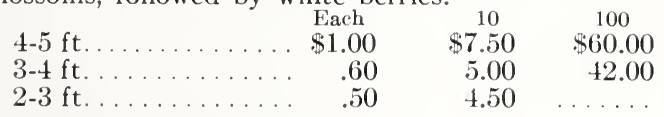

\begin{tabular}{|c|c|c|c|}
\hline $3 \mathrm{ft}$. & $\begin{array}{l}\text { Each } \\
\$ 0.90\end{array}$ & $\begin{array}{c}10 \\
\$ 8.00\end{array}$ & $\begin{array}{c}100 \\
\$ 60.00\end{array}$ \\
\hline $18-24$ in & .75 & 6.00 & 45.00 \\
\hline
\end{tabular}

CYDONIA japonica. Flowering Quince. (S) $6 \mathrm{ft}$. A blaze of scarlet in Spring, then dark green glossy foliage. Ideal for hedge.

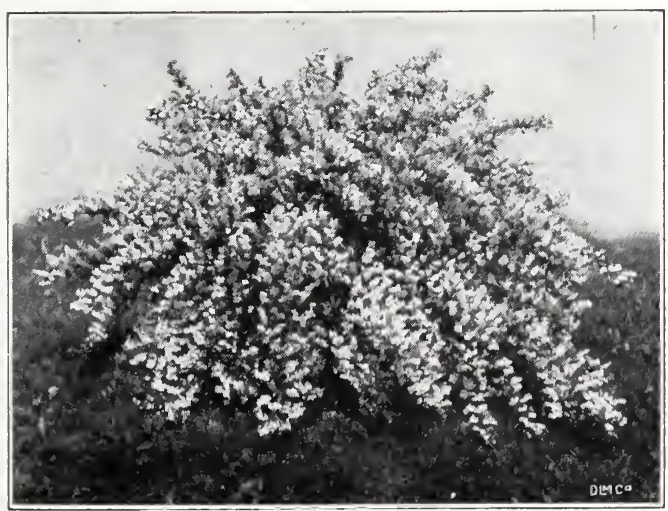

Deutzia graciiis (Slender Deutzia)

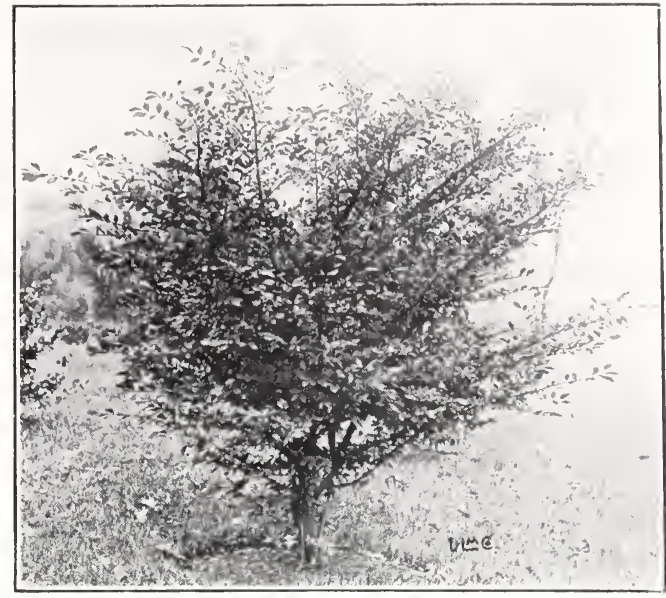

Euonymus alatus (Winged Euonymus). See page 20

DAPHNE mezereum. February Daphne. $4 \mathrm{ft}$. Exquisitely fragrant tiny, purple flowers in very early Spring.

$18-24$ in., B\&B.

$15-18$ in., B\&B.

$\begin{array}{lr}\text { Each } & 10 \\ \$ 2.00 & \$ 18.00 \\ 1.25 & 10.00 \\ 1.00 & 7.50\end{array}$

DEUTZIA gracilis. Slender Deutzia. $3 \mathrm{ft}$. Charming arching branches laden with pure white flowers.

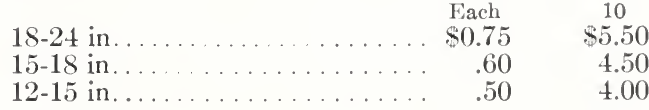

D. gracilis rosea. Rose Deutzia. $3 \mathrm{ft}$. A beautiful pink-flowering variety.

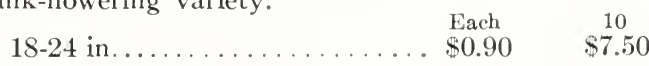

\begin{tabular}{|c|c|c|}
\hline & Each & \\
\hline $2-3 \mathrm{ft}$. & $\$ 0.60$ & $\$ 5.00$ \\
\hline $18-24 \mathrm{i}$ & .50 & 4.00 \\
\hline $15-18 \mathrm{i}$ & .45 & 3.60 \\
\hline
\end{tabular}

D. lemoinei. Lemoine Deutzia. $4 \mathrm{ft}$. Hardy and stout, with luxuriant white flowers in long sprays. Very decorative.

D. scabra crenata. Double Pink Deutzia. $6 \mathrm{ft}$. The pride of this group. Tall, and profusely covered with double white, pink tinged flowers in July.

$$
\begin{aligned}
& 3-4 \mathrm{ft} \text {. } \\
& \text { Each } \\
& \$ 0.75
\end{aligned}
$$

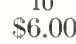

$$
\begin{aligned}
& 2-3 \mathrm{ft} \text {. } \\
& .60
\end{aligned}
$$

D. scabra, Pride of Rochester. Pride of Rochester. 9-10 ft. One of the tallest Deutzias, blooming profusely in July. Large double white flowers, backs of petals tinged rose.

$$
\begin{aligned}
& 5-6 \mathrm{ft} \\
& 3-4 \mathrm{ft} \\
& 2-3 \mathrm{ft} \text {. } \\
& \begin{array}{cc}
\text { Each } & 10 \\
\$ 0.90 & \$ 8.00 \\
.60 & 5.00 \\
.50 & 4.00
\end{array} \\
& 100 \\
& \$ 40.00 \\
& 30.00
\end{aligned}
$$

DIERVILLA trifida. Dwarf Bush-honeysuckle. $3 \mathrm{ft}$. Low lying shrub, yellow flowers in flat-topped clusters. Spreads rapidly by underground shoots and therefore splendid for banks.

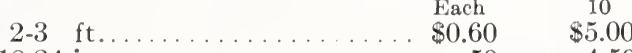

$$
\begin{aligned}
& 18-24 \text { in } \\
& .50 \quad 4.50
\end{aligned}
$$


EUONYMUS alatus. Iringed Euonymus. (S):10 ft. Yellowish flowers followed by red fruit. Distinctive in that the wood is square.

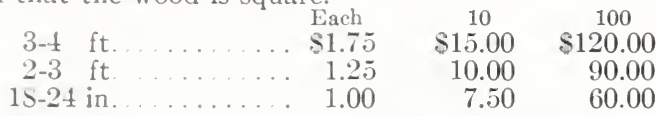

E. europaeus. European Burningbush. (S) $12-14 \mathrm{ft}$. Upright, with foliage turning crimson in Fall. Yellow flowers turning to orange. Scarlet fruit.

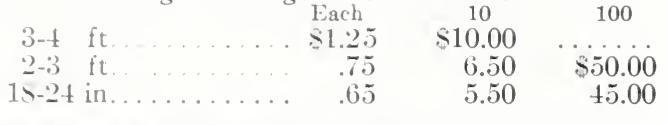

EXOCHORDA grandiflora. Common Pearlbush. 10 ft. Snow-white, pearl-like flowers cover this fine shrub.

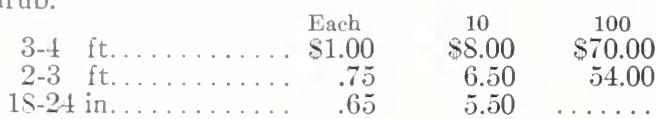

FORS YTHIA intermedia. Border Forsythia. (S) $8 \mathrm{ft}$. This variety has low arching branches.

\begin{tabular}{rrrrr} 
& & Each & \multicolumn{1}{c}{ 10 } & \multicolumn{1}{c}{100} \\
$4-5$ & $\mathrm{ft} . \ldots \ldots \ldots \ldots$ & $\$ 0.75$ & $\$ 6.60$ & $\$ 54.00$ \\
$3-4$ & $\mathrm{ft} . \ldots \ldots \ldots \ldots$ & .60 & 5.00 & 40.00 \\
$2-3$ & $\mathrm{ft} \ldots \ldots \ldots \ldots$ & .50 & 4.00 & 30.00 \\
$1 \$-24$ in $\ldots \ldots \ldots \ldots$ & .40 & 3.30 & 27.00
\end{tabular}

F. intermedia spectabilis. Showy Border Forsythia. $8 \mathrm{ft}$. Freest flowering and the most beautiful.

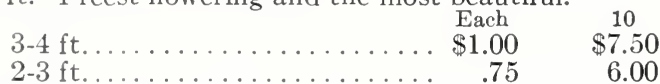

F. suspensa. Weeping Forsythia. $6 \mathrm{ft}$. Showers of sunshine announce Spring! Densely covered with glorious bell-shaped flowers on drooping branches.

$$
\begin{aligned}
& 3-4 \mathrm{ft} \ldots \ldots \ldots \ldots \ldots \ldots \ldots . \$ \ldots 0.75 \quad \$ 6.50
\end{aligned}
$$

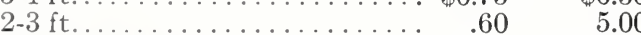

F. suspensa fortunei. Fortune Forsythia. (S) $8 \mathrm{ft}$. Massed deep yellow blossoms, rich foliage turning purplish in Autumn.

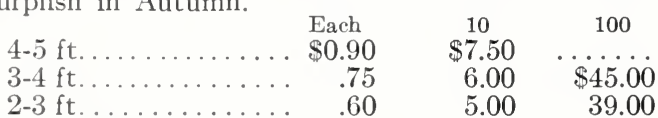

F. viridissima. Greenstem Forsythia. (S) $10 \mathrm{ft}$. Blossoms later and less profusely, but has a more compact and deep green appearance.

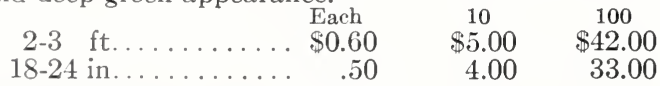

FOTHERGILLA major. Dwarf Alder. 8-10 ft. Hardy, ornamental shrub with long, showy spikes of white flowers; simple green leaves turning golden in Fall.

$$
18-2 t \text { in . . . . . . . . . . . . . . \$3.50 }
$$

HIBISCUS syriacus. Shrub-Althea. 10-12 ft. Hardy, upright growing shrub with profuse pink, white and violet flowers in late July and August. A splendid investment.

$$
\begin{aligned}
& 2-3 \mathrm{ft} \ldots \ldots \ldots \ldots \ldots \ldots \ldots \$ \ldots 0.60 \quad \$ 5.50 \\
& \text { Double Red Double Purple Single Red } \\
& \text { Double White Single Blue Mixed }
\end{aligned}
$$

HYDRANGEA aborescens grandiflora. Snowhill Hydrangea. $5 \mathrm{ft}$. Large clusters of snow-white blossoms on graceful branches. Very hardy; blooms

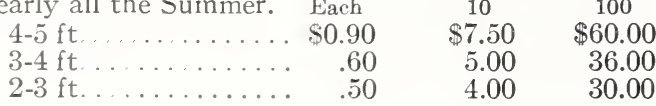

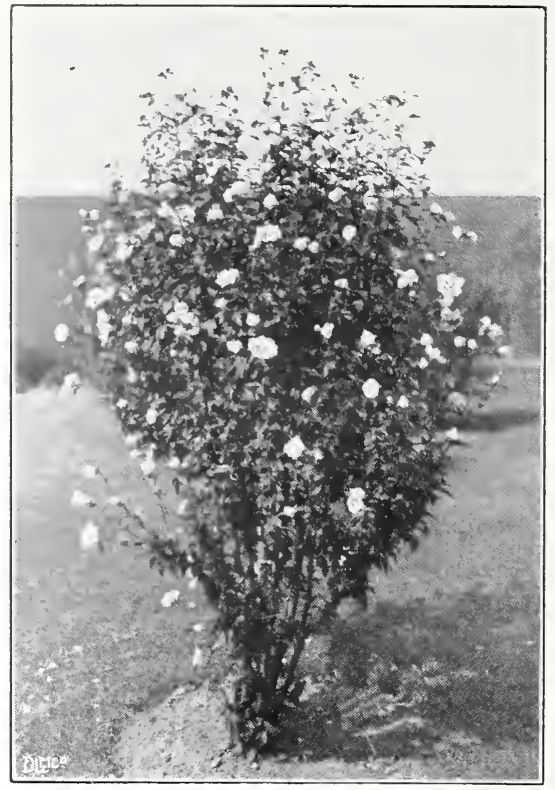

Hibiscus syriacus (Shrub-althea)

H. paniculata. Panicled Hydrangea. $8 \mathrm{ft}$. Tall, upright, with dark green foliage, and long white clusters of flowers in August.

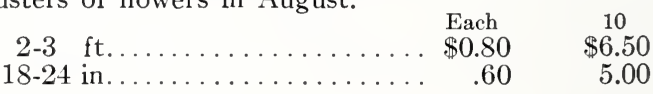

H. paniculata grandiflora. Hydrangea Peegee. (S) $12 \mathrm{ft}$. Large size, with a remarkable change in the huge blossoms from white to rose or bronze with age.

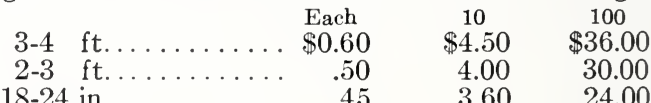

H. radiata. Silver-leaved Hydrangea. $6 \mathrm{ft}$. Flat corymbs of white flowers, with large heart-shaped silver-lined leaves which make this a fine specimen shrub.

\begin{tabular}{crrrr} 
& & Each & \multicolumn{1}{c}{10} & \multicolumn{1}{c}{100} \\
$2-3$ & $\mathrm{ft} . \ldots \ldots \ldots \ldots$ & $\$ 0.60$ & $\$ 5.00$ & $\$ 45.00$ \\
$18-24$ in $\ldots \ldots \ldots \ldots$ & .50 & 4.50 & 39.00
\end{tabular}

HYPERICUM densiflorum. St. Johnswort. $4 \mathrm{ft}$. Upright growing shrub with corymbs of bright yellow flowers from July to September.

$$
\begin{aligned}
& 2-3 \mathrm{ft} \ldots \ldots \ldots \ldots \ldots \ldots \ldots \ldots . \$ \ldots 0.90 \quad \$ 7.50 \\
& 18-24 \text { in } \ldots \ldots \ldots \ldots \ldots \ldots \ldots \ldots . .96 \ldots
\end{aligned}
$$

H. galioides. Bedstraw St. Johnwort. $3 \mathrm{ft}$. Forms usually a low, round bush with handsome dark green foliage; drooping habit and bright yellow flowers.

$2-3 \mathrm{ft} \ldots \ldots \ldots \ldots \ldots \ldots \ldots \ldots \ldots \ldots \ldots . \ldots{ }_{\$ 0.90}$

$18-24$ in. . . . . . . . . . . . . . . .75

ILEX verticillata. Common Winterberry. (S) $4 \mathrm{ft}$. Form of Holly, with small June flowers. Foliage darkly lustrous and exceedingly ornamental with sprinkling masses of crimson fruit. Best in moist soil.

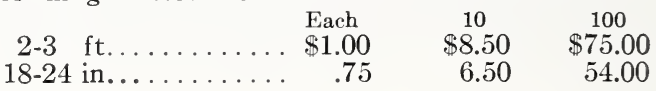


KERRIA japonica. Kerria. $3 \mathrm{ft}$. Exquisitely slender and graceful, with single yellow blossoms throughout Summer.

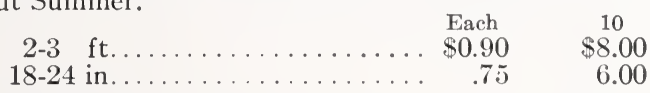

K. japonica flore-pleno. Double Kerria. $5 \mathrm{ft}$. Like the above, with double orange blossoms. Truly lovely.

$2-3 \mathrm{ft} \ldots \ldots \ldots \ldots \ldots \ldots \ldots \ldots \ldots \ldots 1.00 \ldots \ldots$

$18-24$ in

.75

KOLKWITZIA amabilis. Beautybush. $8 \mathrm{ft}$. Something new and fascinating; arching branches, with clusters of bell-like flowers of pink, orange veined; buds of deep pink, charming coloration. This is the Arnold Arboretum's choicest new introduction.

$$
\begin{aligned}
& 2-3 \mathrm{ft} \ldots \ldots \ldots \ldots . \$ 2.00 \quad \$ 18.00 \\
& 18-24 \text { in . . . . . . . . . . . } 1.50 \quad 14.00
\end{aligned}
$$

LIGUSTRUM amurense. Amur Privet. (S) $12 \mathrm{ft}$. Excellent screen or hedge. Grows tall, with white

\begin{tabular}{|c|c|c|c|}
\hline - & Each & 10 & 100 \\
\hline $6-7$ & $\$ 1.00$ & $\$ 9.00$ & \\
\hline & .75 & 5.00 & $\$ 39.00$ \\
\hline & .36 & 2.40 & 18.00 \\
\hline & .30 & 2.10 & 15.00 \\
\hline
\end{tabular}
lilaclike flowers. Hardy.

L. ibota. Ibota Privet (S) $8 \mathrm{ft}$. For Northern climates; graceful, spreading, with white, fragrant flowers and black berries. An excellent hedge plant.

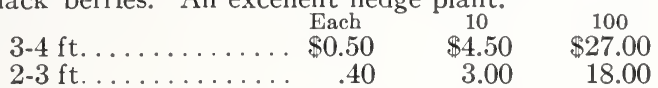

L. ibota regelianum. Regal Privet. (S) $5 \mathrm{ft}$. Compact, spreading, exceptionally hardy, and has a wealth of blue-black berries.

\begin{tabular}{lrrr} 
& \multicolumn{1}{c}{ Each } & \multicolumn{1}{c}{10} & \multicolumn{1}{c}{100} \\
$3-4 \mathrm{ft} . \ldots \ldots \ldots \ldots \ldots$ & $\$ 0.70$ & $\$ 6.00$ & $\$ 45.00$ \\
$21 / 2-3 \mathrm{ft} \ldots \ldots \ldots \ldots \ldots$ & .60 & 5.00 & 39.00 \\
$2-21 / 2 \mathrm{ft} \ldots \ldots \ldots \ldots \ldots$ & .50 & 4.00 & 33.00
\end{tabular}

L. ovalifolium. California Privet. (S) $12 \mathrm{ft}$. Upright, with glossy green foliage. Good hedge plant. 100

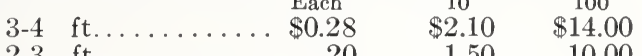

$$
\begin{aligned}
& 2-3 \text { ft.......... } 20 \quad .20 \quad 1.50 \quad 10.00 \\
& \begin{array}{rrr}
18-24 \text { in........ } & .18 \quad 1.20 \quad 9.00
\end{array}
\end{aligned}
$$

L. vulgare. European Privet. $15 \mathrm{ft}$. Tall, spreading;

\begin{tabular}{|c|c|c|}
\hline & $\begin{array}{l}\text { Each } \\
\$ 040\end{array}$ & $\$ 300$ \\
\hline
\end{tabular}
very hardy. White flowers against a background of gray-green foliage, followed by clusters of black berries.

LONICERA fragrantissima. Winter Honeysuckle. (B) $8 \mathrm{ft}$. Very early, sweet-scented white flowers, with

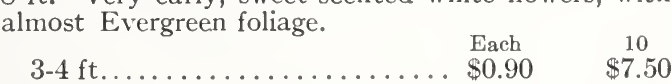

L. morrowi. Morrow Honeysuckle. (B-S) $12 \mathrm{ft}$. Pendulous branching, with cream-white flowers deliciously fragrant; red fruit remaining all Fall.

\begin{tabular}{llrr}
$3-4 \mathrm{ft} . \ldots \ldots \ldots \ldots \ldots$ & $\begin{array}{l}\text { Each } \\
2-3 \mathrm{ft} . \ldots \ldots \ldots \ldots \ldots \ldots\end{array}$ & \multicolumn{1}{c}{10} & \multicolumn{1}{c}{100} \\
& .50 & $\$ 5.00$ & $\$ 36.00$ \\
& 4.00 & 30.00
\end{tabular}

L. ruprechtiana. Manchurian Honeysuckle. (B) $12 \mathrm{ft}$. Yellow blossoms, fruit coral; decorative.

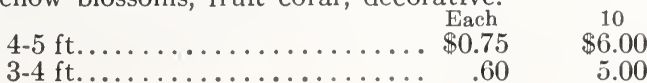

L. tatarica. Tatarian Honeysuckle. (B-S) $10 \mathrm{ft}$. Tall, with pink flowers in early Spring; red fruit which attracts birds to feast.

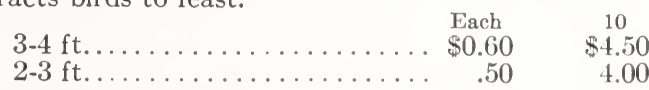

L. tatarica alba. White Tatarian Honeysuckle. (B-S) $10 \mathrm{ft}$. White, dainty blossoms and later red fruit.

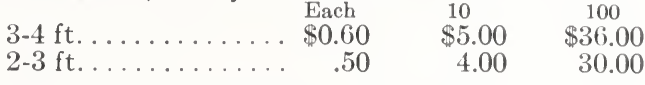

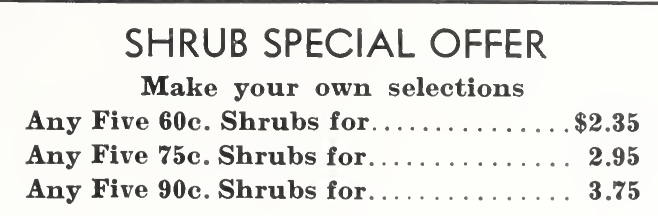

PHILADELPHUS coronarius. Sweet Mockorange. (S) $10 \mathrm{ft}$. Always alluringly lovely, with waxy, white, fragrant flowers. Useful for cut flowers and background because of its verdant foliage.

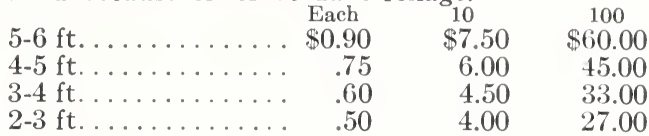

P. coronarius aureus. Golden Mockorange. $6 \mathrm{ft}$. Dwarf, compact, with golden leaves and white blossoms. Excellent for low border shrub.

$12-15$ in . . . . . . . . $\ldots \ldots . \$ 0.75 \quad \$ 6.00$

P. gordonianus. Gordon Mockorange. (S) $10 \mathrm{ft}$. Late blossoming white, with gray-brown branches.
4-5 $\mathrm{ft}$.
$\$ 0.75$

\begin{tabular}{|c|c|c|}
\hline - the & Each & \\
\hline $5-6 \mathrm{ft} .$. & $\$ 0.90$ & $\$ 6.50$ \\
\hline $4-5 \mathrm{ft} . \ldots$ & .75 & 5.00 \\
\hline $4 \mathrm{ft}, \ldots \ldots \ldots \ldots \ldots$ & .60 & 4.00 \\
\hline
\end{tabular}
$\$ 6.50$

P. grandiflorus. Big Scentless Mockorange. (S) $10 \mathrm{ft}$. Very large white flowers; rapid grower.

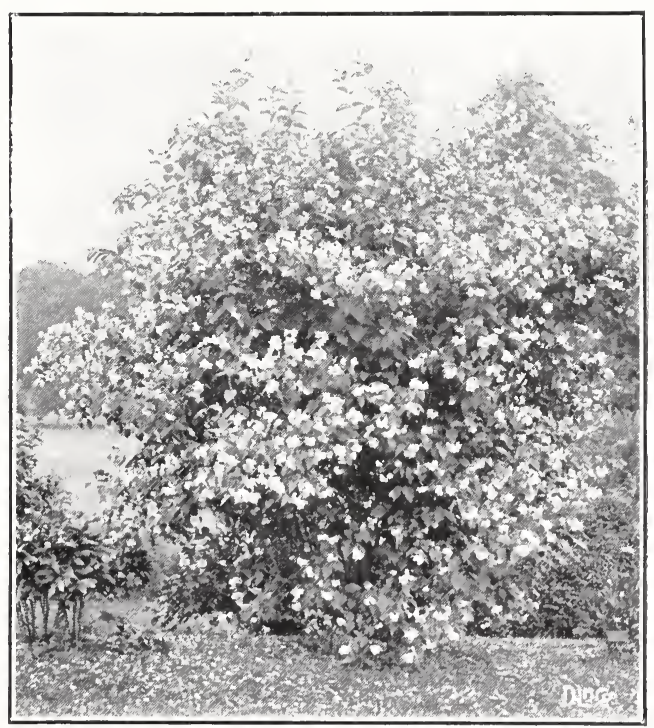

Philadelphus coronarius (Sweet Mockorange) 


\section{PHILADELPHUS - Continued}

\section{HYBRID MOCKORANGE}

This group is the result of years of experiment by the famous Lemoine of France. That he has won complete success is evident because of the growing popularity of the shrubs.

Avalanche. $6 \mathrm{ft}$. Literally a landslide of white blossoms all along the drooping branches.

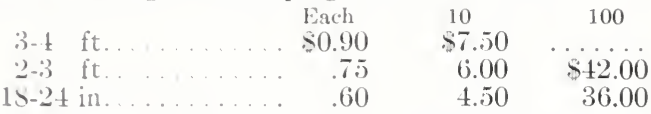

Brachybotrys. \& $\mathrm{ft}$. This long-stemmed hybrid is covered with pure white Howers.

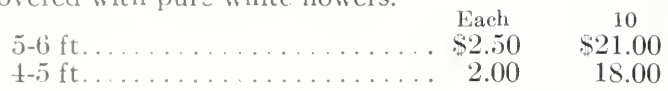

Glacier. Double rich creamy flowers produced in thick clusters of five to seven blooms.

$$
15-1 \text { in . . . . . . . . . . } \$ 0.75 \quad \$ 6.00
$$

Lemoine. $6 \mathrm{ft}$. Upright, with pure white, fragrant blossoms in June.

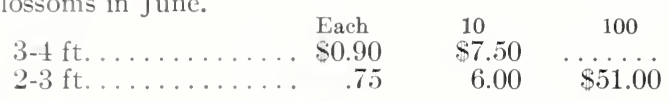

Mont Blanc. $4 \mathrm{ft}$. Dwarf sort, with large, delightfully fragrant flowers.

$$
\begin{aligned}
& \begin{array}{lll}
2-3 \mathrm{ft} \ldots \ldots & \begin{array}{l}
\text { Each } \\
\$ 0.75
\end{array} & \$ 6.00
\end{array} \\
& 18-24 \text { in ............... } \quad 65 \quad 5.50
\end{aligned}
$$

Virginal. \& ft. The height of development. Snowy white, very large, double blossoms which continue to grow all Summer and even the Fall. This is a perfect joy, though not as fragrant as the old-time "coronarius."

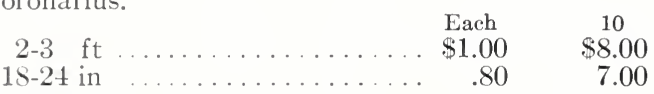

PHYSOCARPUS intermedius. Illinois Ninebark. (S) $14 \mathrm{ft}$. A prolific grower, tall with golden leaves.

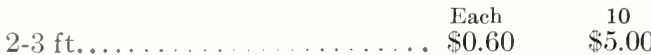

P. opulifolius. Common Ninebark. (S) $14 \mathrm{ft}$. Sturdy shrub with bark hanging by shreds along stems upon which white flowers grow. An interesting effect.

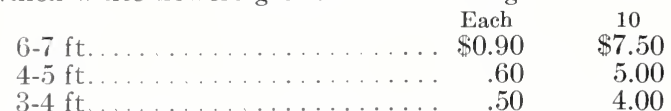

P. aureus. Goldleaf Ninebark. $14 \mathrm{ft}$. Similar to opulifolius, but has bright yellow foliage.

$$
2 \mathrm{ft} \ldots \ldots \ldots \ldots \ldots \ldots \ldots . \ldots 0.40 \quad \begin{gathered}
\text { Each } \\
\$ 0.40
\end{gathered}
$$

PRUNUS glandulosa albaplena. Double Pinkflowering Almond. $8 \mathrm{ft}$. Charming pink clusters on droop-

ing branches in early Spring.
$2-3 \mathrm{ft} \ldots \ldots \ldots \ldots \ldots \ldots \ldots \ldots . \$ 1.00$

P. glandulosa sinensis. Double Whiteflowering Almond. $8 \mathrm{ft}$. May time brings an abundance of full, white flowers.

$2-3 \mathrm{ft} \ldots \ldots \ldots \ldots \ldots \ldots \ldots . \ldots 1.00 \quad \begin{aligned} & \text { Each } \\ & \$ 8.00\end{aligned}$

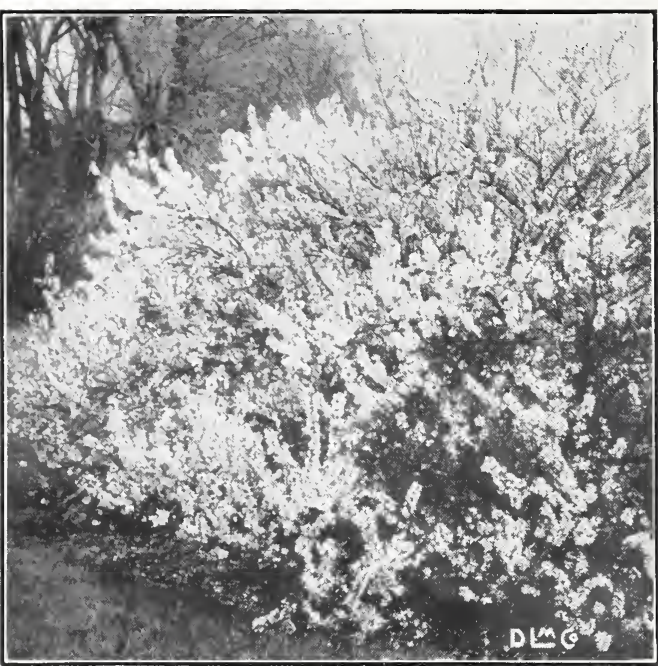

Prunus tomentosa (Nanking Cherry)

P. tomentosa. Nanking Cherry. $8 \mathrm{ft}$. An exceptionally fine possession. Has a profusion of light pink blossoms, followed by delicious edible red fruit. Perfectly

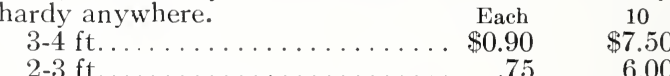

P. triloba. Flowering Plum. $8 \mathrm{ft}$. Another joy. Delicate double pink blossoms set on gracefully pendulous branches. Hardy.

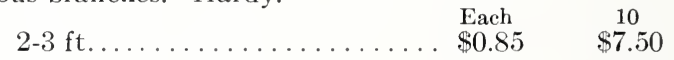

RHODOTYPOS kerrioides. Jetbead. (S) $5 \mathrm{ft}$. IVaxy white flowers, followed by black shiny berries.

$2-3 \mathrm{ft}$ Each
$\$ 0.60$ $\$ 5.00$

RHUS canadensis. Fragrant Sumac. (S) $5 \mathrm{ft}$. Low spreading, fragrant leaves, yellow flowers.

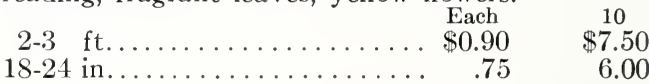

R. cotinus. Common Smoketree. $12 \mathrm{ft}$. A mist of pale purple blossoms makes this a fascinating addition to a home lawn.
$3-4 \mathrm{ft}$.
Each
$\$ 1.25$
$\$ 10.00$

ROSA hugonis. Ingonis Rose. $6 \mathrm{ft}$. The charm of the yellow Rose is at its best in this shrub, with its long garlands of single $2 \frac{1}{2}$ inch blossoms.

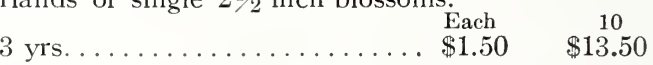

R. rugosa. Rugosa Rose. (B-S) $5 \mathrm{ft}$. Blooms profusely. Red single Roses, followed by red fruit. Hardy at seashore; makes beautiful hedge.

18
$18-24-i n \ldots \ldots \ldots \ldots \ldots \ldots \ldots$

\section{For HYBRID RUGOSA, see Roses.}

R. setigera. Prairie Rose. (S) $8 \mathrm{ft}$. Fond of trailing over stones or trellis, and spreading joy with its exquisite deep rose-colored blossoms.

$3-4 \mathrm{ft}$

Each

$\$ 0.60$

10

$2-3 \mathrm{ft}$. 4.00 
ROSA-Continued

R.'spinosissima. Scotch Rose. $3 \mathrm{ft}$. Bristle covered branches and solitary white or yellow flowers.

$2-3 \mathrm{ft} \ldots \ldots \ldots \ldots . \$ 1.25 \quad \$ 10.00$

R.'spinosissima altaica. Altai Rose. $8 \mathrm{ft}$. Larger, more vigorous species than the above. White flowers.

$$
\begin{array}{ccc}
3-4 \mathrm{ft} . \ldots \ldots \ldots \ldots & \text { Each } & 10 \\
\$ 1.75 & \$ 16.00
\end{array}
$$

R.'wichuraiana. Wichurian Rose. (S) A creeper, making a close covering of glossy foliage, and in the late Summer, fragrant clusters of white flowers.

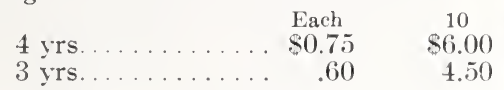

SAMBUCUS canadensis. American Elder. S ft. (S) Tall shrub with masses of dainty white blossoms.

\begin{tabular}{rrr} 
& \multicolumn{1}{c}{$\begin{array}{l}\text { Each } \\
3-4 \mathrm{ft} \ldots \ldots \ldots \ldots \ldots\end{array}$} \\
$2-3 \mathrm{ft} \ldots \ldots \ldots \ldots \ldots$ & .50 & $\$ 5.00$ \\
& 4.09
\end{tabular}

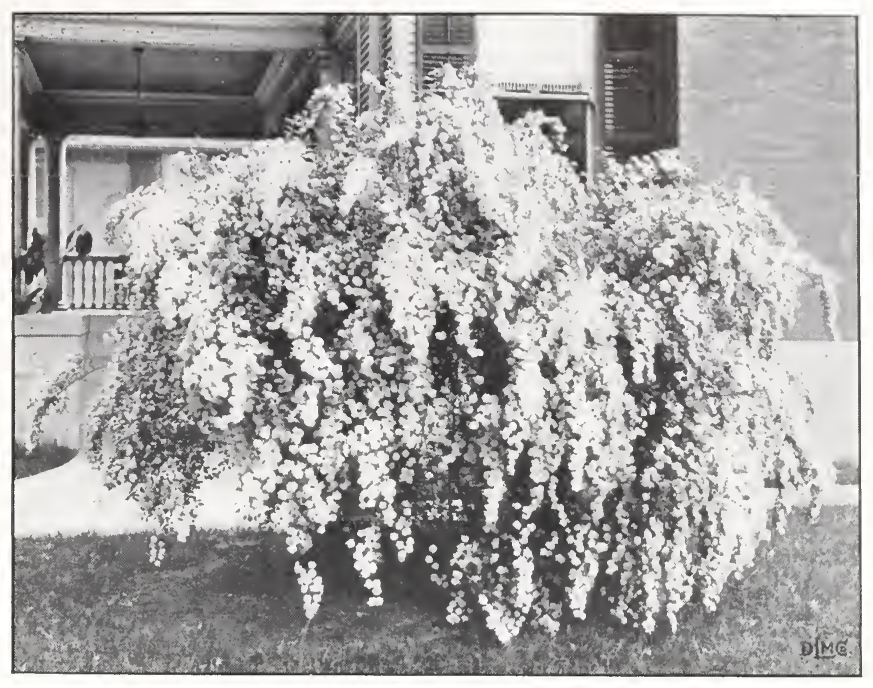

S. nigra laciniata. Cutleaf European Elder (S) $12 \mathrm{ft}$. Attractive with panicles of yellowish-white flowers followed by scarlet fruit.

\begin{tabular}{rrr}
$4-5 \mathrm{ft} \ldots \ldots \ldots \ldots \ldots \ldots \ldots \ldots \ldots \ldots$ & $\begin{array}{c}\text { Each } \\
\$ 1.00\end{array}$ & \multicolumn{1}{c}{10} \\
$3-4 \mathrm{ft} \ldots \ldots \ldots \ldots \ldots \ldots \ldots \ldots \ldots$ & .75 & $\$ 6.00$ \\
$2-3 \mathrm{ft} \ldots \ldots \ldots \ldots \ldots \ldots \ldots \ldots \ldots$ & .60 & 5.00
\end{tabular}

SPIRAEA arguta. Garland Spirea. (S) $6 \mathrm{ft}$. An early bower of clustered white flowers.

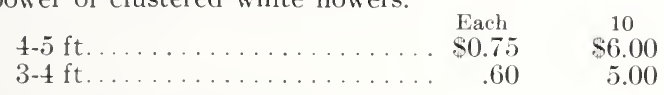

S. bumalda. Bumalda Spirea. (S) $5 \mathrm{ft}$. Spreading low bush with dark foliage relieved by corymbs of light pink flowers in May and all during Summer.

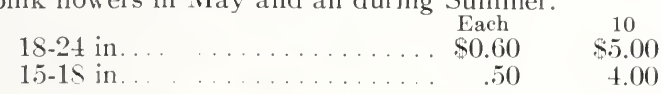

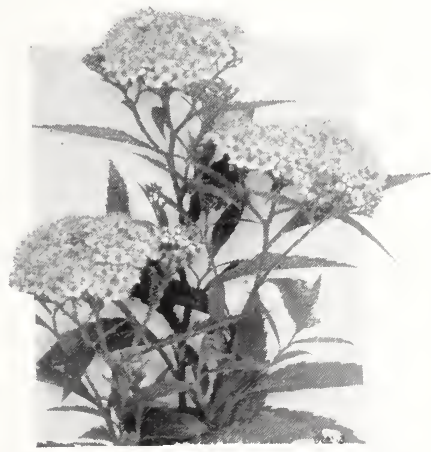

Spiraea bumalda, Anthony Waterer

$$
\text { (Anthony Waterer Spirea) }
$$

\section{SHRUB SPECIAL OFFER \\ Make your own selections}

Any Five 60c. Shrubs for

Spiraea vanhouttei (Tanhou'ie Sprete)

S. bumalda Anthony Waterer. Anthony Waterer Spirea. (S) $3 \mathrm{ft}$. Dwarf form, with deep rose-colored corymbs, blossoming the whole season.

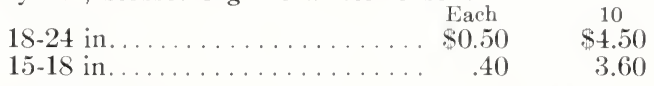

S. bumalda froebeli. Froebel Spirea. (S) $4 \mathrm{ft}$. A trifle taller than the above. Bronze-red foliage in Spring and Fall. Reddish pink corymbs in July and August.

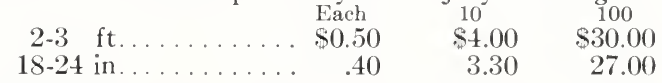

S. douglasi. Douglas Spirea. (S) $7 \mathrm{ft}$. Grows upright, reddish brown branches. Narrow, oblong leaves, bearing beautiful deep-rose-colored flowers in July.

$$
2-3 \mathrm{ft} \ldots \ldots \ldots \ldots \ldots \ldots . \ldots .50 .50 \ldots
$$

S. japonica ovalifolia (callosa alba.) White Japanese Spirea. $3 \mathrm{ft}$. Symmetrical dwarf form, suitable for borders or hedges.
$15-18$ in.
Each
$\$ 10$

S. prunifolia. Bridalwreath. $7 \mathrm{ft}$. Tiny double white flowers massed along the graceful stems in May.

\begin{tabular}{|c|c|c|}
\hline $.5 \mathrm{ft}$ & $\begin{array}{l}\text { Each } \\
\$ 125\end{array}$ & $\begin{array}{c}10 \\
\$ 1000\end{array}$ \\
\hline $3-4 \mathrm{ft}$ & .90 & $\begin{array}{r}\$ 10.00 \\
7.50\end{array}$ \\
\hline$\ldots \ldots \ldots \ldots \ldots \ldots$ & .75 & 6.00 \\
\hline
\end{tabular}
$3-4 \mathrm{ft}$.
$\$ 0.75 \$ \$ 6.50$
$2-3 \mathrm{ft}$.
$65 \quad 5.50$

S. thunbergi. Thunberg Spirea. $8 \mathrm{ft}$. Recommended highly for its lovely April flowers.

S. trichocarpa. Korean Spirea. S ft. A new variety with arching branches and large clustered blooms.

$$
\begin{array}{rrrr}
2-3 \mathrm{ft} \ldots \ldots \ldots \ldots \ldots & \$ 1.00 & \$ 9.00 & \$ 75.00 \\
18-24 \text { in } \ldots \ldots \ldots \ldots & .75 & 6.50 & 54.00
\end{array}
$$

S. vanhouttei. Vanhoutte Spirea. (S) $8 \mathrm{ft}$. Unparalleled for graceful arching of branches and luxuriance of green foliage and white flowers.

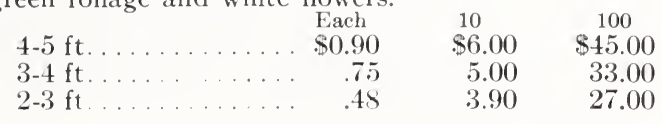


STEPHANANDRA flexuosa. Cutleaf Stephanandra. $6 \mathrm{ft}$. Leaves fernlike, pendulous branches, and masses of creamy-white flowers. A delightful bit of delicacy.

$2-3 \mathrm{ft} \ldots \ldots \ldots \ldots . \$ 80.60 \quad \$ 5.00 \quad \$ 45.00$

SYMPHORICARPOS chenaulti. Snowberry. $6 \mathrm{ft}$. A lovely hybrid from the Arnold Arboretum. Small, red, dotted fruit all Summer and Autumn. A unique \begin{tabular}{rrrr} 
possession. & \multicolumn{1}{c}{ Each } & \multicolumn{1}{c}{10} & \multicolumn{1}{c}{100} \\
$3-4 \mathrm{ft} \ldots \ldots \ldots \ldots$ & $\$ 1.10$ & $\$ 9.75$ & $\ldots \ldots \ldots$ \\
$2-3 \mathrm{ft} \ldots \ldots \ldots \ldots$ & .90 & 7.50 & $\$ 66.00$ \\
$1 \$-24 \mathrm{in} . \ldots \ldots \ldots \ldots$ & .75 & 6.50 & 54.00
\end{tabular}

S. racemosus. Common Snowberry. $6 \mathrm{ft}$. (S) Waxy white berries that hang all IVinter.

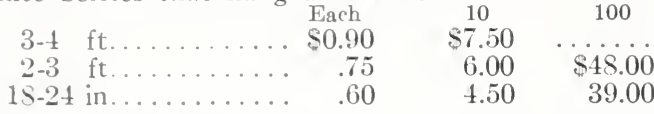

S. rulgaris. Coralberry. (S) $6 \mathrm{ft}$. Slender branches, covered with coral-red berries in Autumn. Rapid

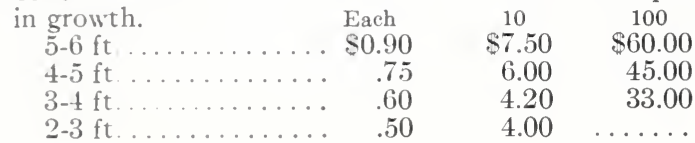

SYRINGA chinensis (rothomagensis). Chinese Lilac. $12 \mathrm{ft}$. One of the finest tall, violet-blue varie-

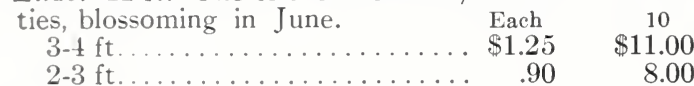

S. josikaea. HungarianLilac. $12 \mathrm{ft}$. Vigorous, treelike growth, dark, shining leaves and bluish purple flowers in June $3-4 \mathrm{ft}$

$\begin{aligned} \text { Each } & 10 \\ \$ 1.75 & \cdots\end{aligned}$
$2-3 \mathrm{ft}$$$
1.50
$$

S. villosa. Late Lilac. $18 \mathrm{ft}$. Bright green foliage with light purple buds which are rosy white when open.

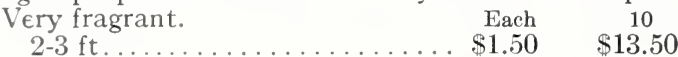

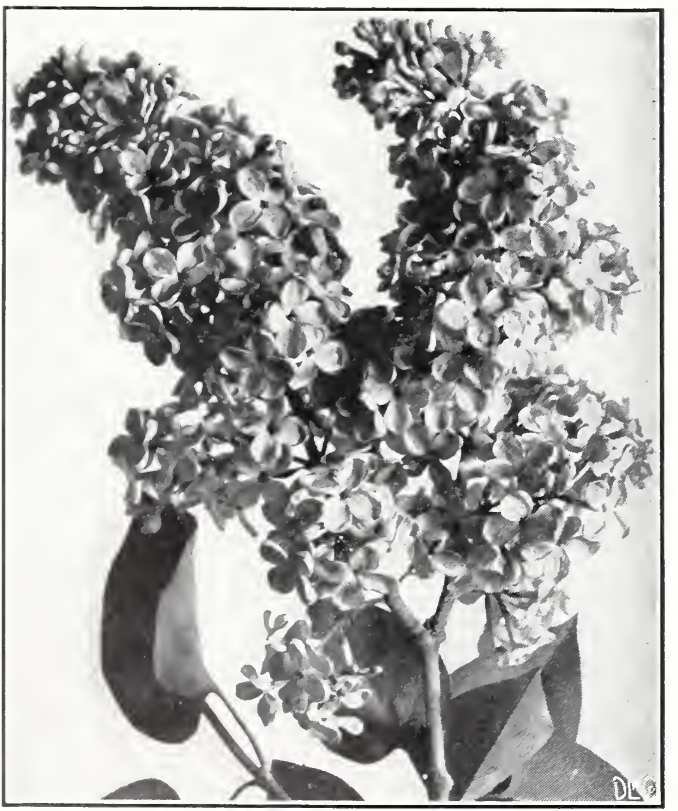

Hybrid Lilac,"Charles the Tenth

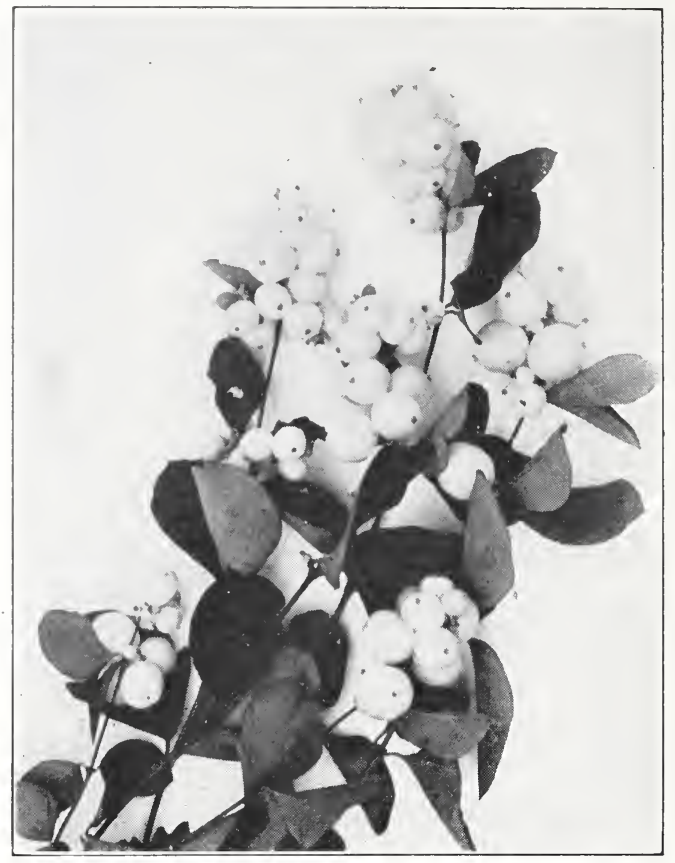

Symphoricarpos racemosus (Common Snowberry)

S. vulgaris. Common Lilac. (S) $12 \mathrm{ft}$. Sturdy growth, with profuse panicles of purplish flowers appearing in May.

$4-5 \mathrm{ft} \ldots \ldots \ldots \ldots \ldots \ldots \ldots \ldots \ldots$
$3-4 \mathrm{ft} \ldots \ldots \ldots \ldots \ldots \ldots \ldots \ldots$

$\begin{array}{rrr}3-4 \mathrm{ft} \ldots \ldots \ldots \ldots \ldots \ldots \ldots \ldots \ldots & .90 & .90\end{array}$

S. vulgaris alba. Common White Lilac. (S) $12 \mathrm{ft}$. Exquisitely scented pure white blossoms.

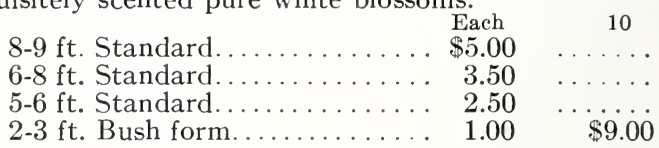

\section{HYBRID LILACS}

Too few of us appreciate the hybrid and improved varieties of Lilacs. Unlike the white and purple kinds long familiar to us, they bloom when very small plants, and can be kept in fairly limited space. It is a small garden that has no room for an assortment of these splendid shrubs.

Ambroise Verschaffelt. Single, white, tinged Laelia pink.

$2-3 \mathrm{ft} . \ldots \ldots \ldots \ldots \ldots \ldots \ldots . \$ 1.50 \quad \$ 14.00$

Amoena. Single Chinese violet, shading to Tourmaline pink. Large and numerous clusters.

$$
\begin{aligned}
& 3-4 \mathrm{ft} \ldots \ldots \ldots \ldots \ldots \ldots \ldots . \$ 1.75 \quad \$ 16.00 \\
& 2-3 \mathrm{ft} . \ldots \ldots \ldots \ldots \ldots \ldots \ldots \ldots \ldots, 1.50 \quad 14.00
\end{aligned}
$$

Charles the Tenth. Beautiful clusters of single red$\begin{array}{llll}\text { dish-purple flowers. } & \text { Each } & 10 & 100\end{array}$ $3-4 \mathrm{ft} \ldots \ldots \ldots \ldots \ldots \$ 1.75 \quad \$ 15.00 \quad \$ 120.00$ $2-3 \mathrm{ft} \ldots \ldots \ldots \ldots \ldots . \quad 1.50 \quad 13.50 \quad 114.00$

Dr. von Regel. Compact clusters of pale Laelia pink with margin of white. Single. Each 10 $2-3 \mathrm{ft} . \ldots \ldots \ldots \ldots \ldots \ldots \ldots \ldots \$ 1.50 \quad \$ 14.00$

Giant. Large single clusters, shading from purple to violet. Very choice. Each 10 $3-4 \mathrm{ft} \ldots \ldots \ldots \ldots \ldots \ldots \ldots \ldots+\ldots \ldots$ $2-3 \mathrm{ft} \ldots \ldots \ldots \ldots \ldots \ldots \ldots \ldots, 1.50 \quad 13.50$ 


\section{SHRUB SPECIAL OFFER \\ Make your own selections}

Any Five 60c. Shrubs for

Any Five 75c. Shrubs for

2.95

Any Five 90c. Shrubs for

3.75

HYBRID LILACS - Continued

Jacques Callot. Single rosy-pink flowers. $2-3 \mathrm{ft}$

Each $\$ 1.50$

Justi. Single bluish lilac.

$2-3 \mathrm{ft}$. .

Each

$\$ 1.50$

Ludwig Spaeth. Single dark red.

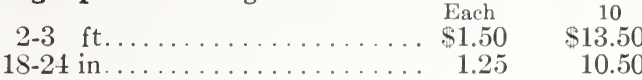

Michel Buchner. Large double pale-lilac flowers; dwarf.

\begin{tabular}{|c|c|}
\hline & Each \\
\hline $\begin{array}{l}3-4 \mathrm{ft} \\
2-3 \mathrm{ft}\end{array}$ & $\begin{array}{r}\$ 1.75 \\
1.25\end{array}$ \\
\hline
\end{tabular}

Mme. Casimir Perier. Double cream white.

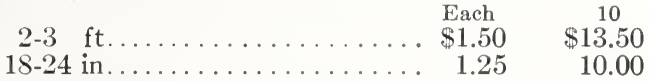

Mme. Lemoine. Large double white; inmense clusters.

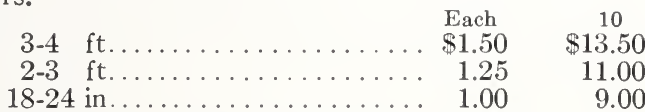

Mme. Moser. Beautiful single white clusters.

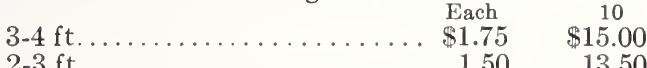

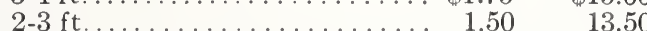

President Grevy. Pale blue panicles of exquisite beauty.

\begin{tabular}{|c|c|}
\hline & Each \\
\hline $2-3 \mathrm{ft}$ & 1.50 \\
\hline
\end{tabular}

President Loubet. Light mauve, with white markings on center of lobes.

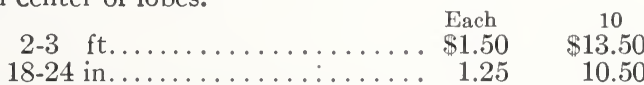

Senateur Volland. Double compact clusters Tourmaline pink, shading to lilac.

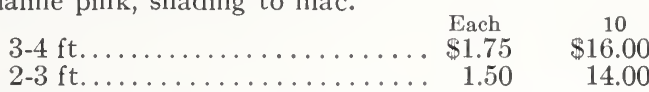

Volcan. Dull magenta purple. Single.

$2-3 \mathrm{ft} . \ldots \ldots \ldots \ldots \ldots \ldots \ldots \ldots+\$ \ldots 1.50$

10

$\$ 13.50$

$18-24$ in $. . . \cdots+1.25$

10.50

Mixed.

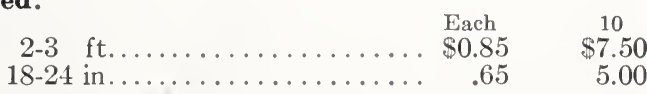

VACCINIUM corymbosum. Highbush Blueberry. (S) 5-6 ft. A native of New England, with pink tinged white flowers and edible fruit. Has beautiful Fall foliage, almost scarlet.

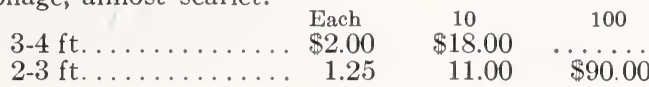

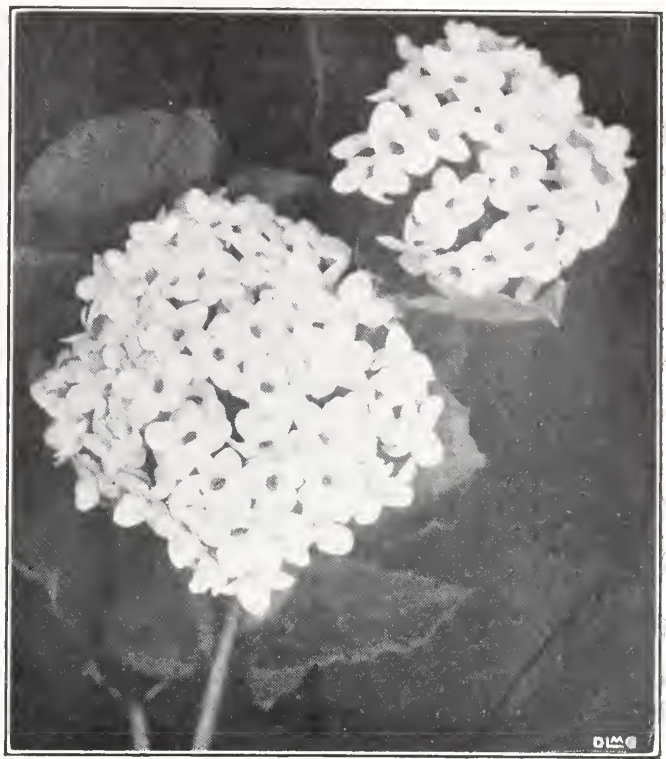

Viburnum carlesi (Fragrant Viburnum)

VIBURNUM americanum. American Cranberrybush. (S) $12 \mathrm{ft}$. A hardy shrub bearing white flowers in June and loaded with gorgeous red fruit in Fall and Winter. Useful for jelly.

$4-5 \mathrm{ft} . \ldots \ldots \ldots \ldots \ldots \ldots \ldots . \$ 1.00 \quad \begin{aligned} & \text { Each } \\ & \$ 8.40\end{aligned}$

V. carlesi. Fragrant Viburnum. $4 \mathrm{ft}$. Compact, bushy growth with pale rosy-pink flowers of exquisite fragrance.

$18-24$ in., B\&B................. $\$ 2.50$

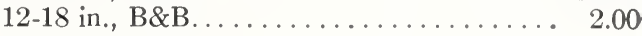

V. cassinoides. Withe-rod. (S) 5-6 ft. Creamy white flowers, followed by berries, first pink, then blue. Thrives in a moist soil as well as dry.

$$
\begin{aligned}
& 3-4 \mathrm{ft} \text { Each } 10 \\
& 2-3 \mathrm{ft} \ldots \ldots \ldots \ldots \ldots \ldots \ldots \ldots \ldots, \quad .90 \quad \%, \quad 7.50
\end{aligned}
$$

V. dentatum. Arrowwood. (S) 10-12 ft. Rougly heartshaped leaves, becoming richly red in Fall. White flowers followed by blue berries. A fine hedge plant.

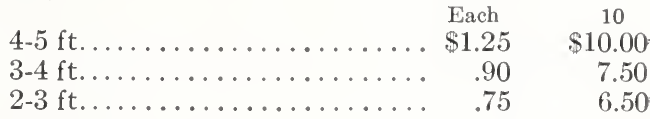

V. lantana. Wayfaring-tree. 15-18 ft. Robust growth with clusters of white flowers in May, followed by red fruit, which turns black in Autumn.

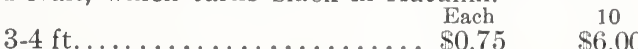

V. lentago. Nannyberry. 18-20 ft. Creamy white

\begin{tabular}{|c|c|c|c|}
\hline & Each & 10 & 100 \\
\hline $5-6$ & $\$ 1.25$ & $\$ 10.00$ & \\
\hline & 1.00 & 7.50 & $\$ 63.00$ \\
\hline 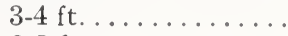 & .75 & 6.00 & 52.00 \\
\hline . & .65 & 5.10 & 45.00 \\
\hline
\end{tabular}
fragrant flowers, with bluish-black fruit. 


\section{VIBURNUM1 - Continued}

V. opulus. European Cranberrybush. s-9 ft. White flowers in panicles, and red berries which remain until

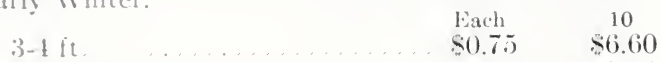

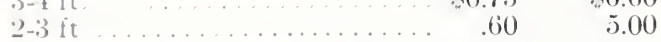

V. opulus sterile. Common Snowball. 9-10 ft. Oldfashioncel and delightful is this sturdy, hardy shrub with round clustered Howers.

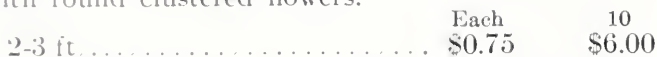

V. sieboldi. Siebold Tiburnum. $10 \mathrm{ft}$. Rich green foliage, with white flowers in clusters. Pink berries, turning blue-black.

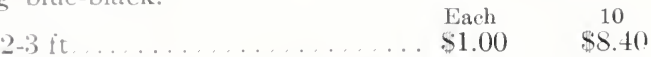

V. tomentosum. Doublefile Viburnum. 7-8 ft. Flat racemes of white flowers borne in great profusion on sturdy branches. An excellent variety.

$$
2-31 t \ldots \ldots \ldots \ldots \ldots . \$ 1.00 \quad \$ 8.00
$$

V. tomentosum plicatum. Japanese Snowball. $7-8 \mathrm{ft}$. A sturdy type with rich foliage and large globular heads of snow whiteness.

$$
\begin{aligned}
& 2-3 \quad \text { it } \ldots \ldots \ldots \ldots \ldots
\end{aligned}
$$

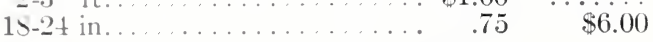

WEIGELA floribunda. Crimson Weigela. $7 \mathrm{ft}$. Abounding in tubular flowers in a background of deep foliage.

$2-3 \mathrm{ft} \ldots \ldots \ldots \ldots \ldots \ldots \ldots . \$ 0.60 \quad \$ 5.00$

W. rosea. Pink Iteigela. $6 \mathrm{ft}$. Large, bell-shaped blossoms appearing profusely in June.

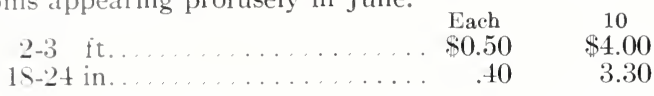

\section{SHRUB SPECIAL OFFER}

Make your own selections

Any Five 60c. Shrubs for

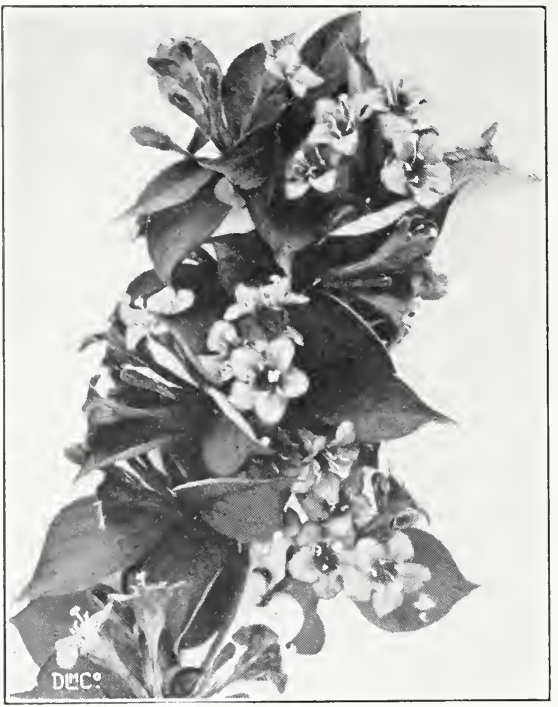

Weigela, Eva Rathke

W. rosea variegata. Variegated Weigela. $6 \mathrm{ft}$. Dwarf leaves, broadly margined in white; white flowers.

$$
2-3 \mathrm{ft} \ldots \ldots \ldots \ldots \ldots \ldots \ldots \ldots . \$ \ldots 0.75 \quad \$ 6.00
$$

\section{HYBRID VARIETIES}

W. candida. Snow Weigela. $7 \mathrm{ft}$. Vigorous growth with unusually large white flowers. Each $2-3 \mathrm{ft} \ldots \ldots \ldots \ldots \ldots \ldots \ldots \ldots \ldots \ldots \ldots . \ldots 0$

W. desboisi. Desbois Weigela. $7 \mathrm{ft}$. Richly hued in deep rose. A lovely shrub, though smaller in blossom.

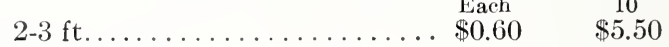

W. Eva Rathke. Eva Rathke. $4 \mathrm{ft}$. Low growing, with dark brownish-red flowers.

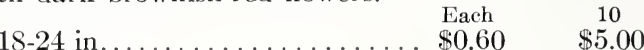

ZANTHORHIZA apiifolia. Yellowroot. $2 \mathrm{ft}$. Dwarf shrub, valuable as ground cover. Soft, plum-colored flowers in misty profusion. Hardy.

Each $10-12$ in . . . . . . . . . . . . . $\$ 0.40$

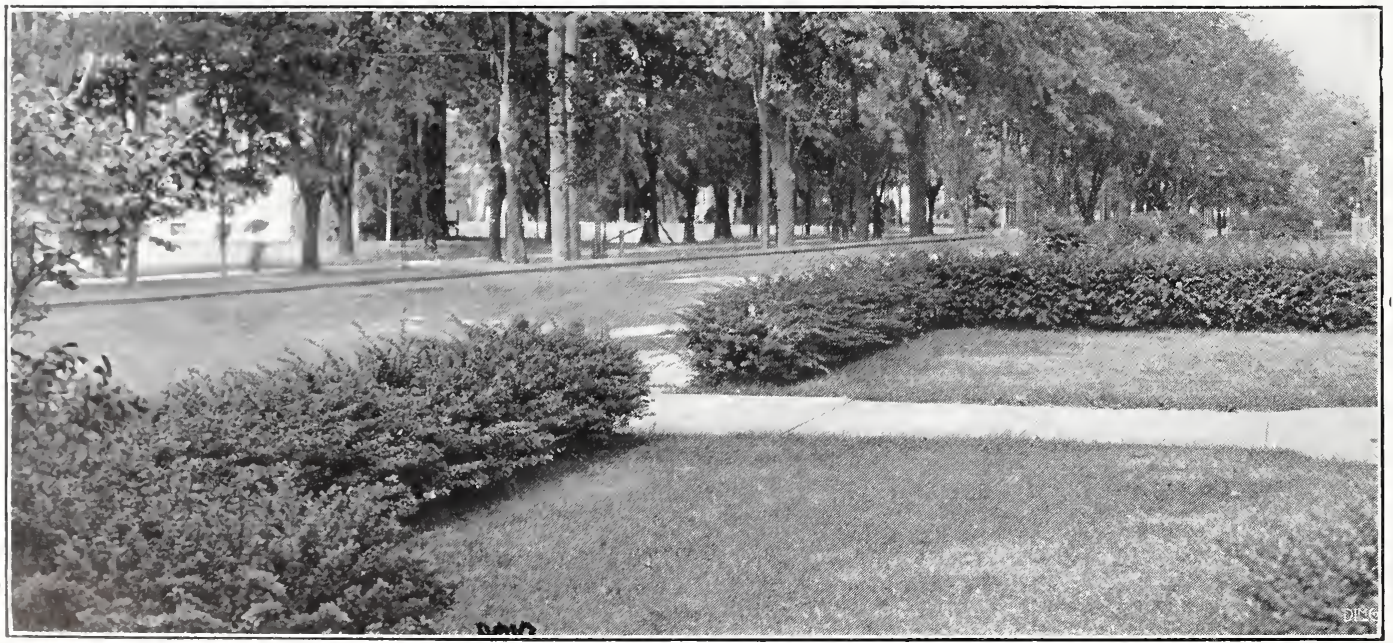

Berberis thunbergi hedge (Japanese Barberry). See page 18 


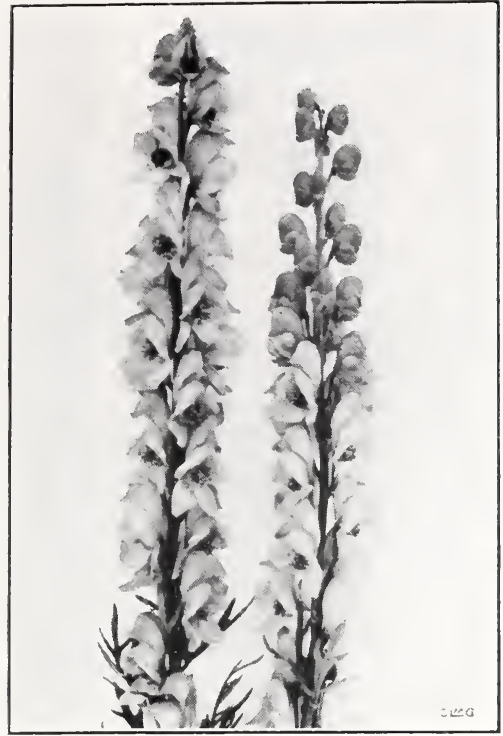

Aconitum fischeri (Azure Monkshood)

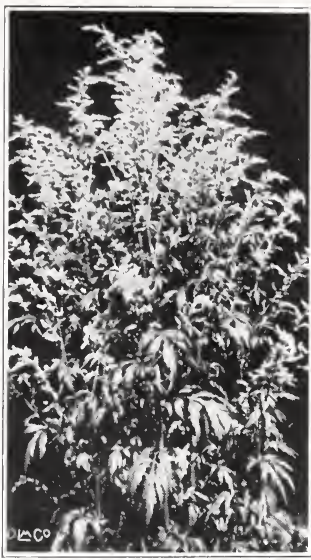

Artemisia, Silver King See page 28

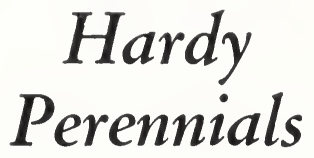

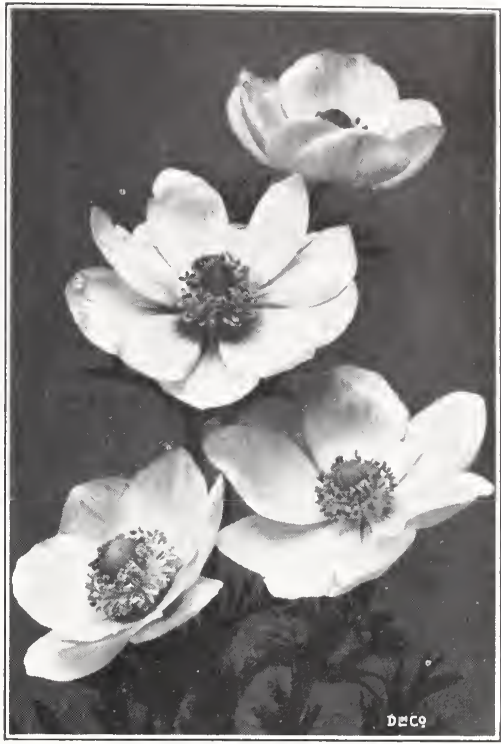

Anemone. See page 2

\section{Hints for Successful Culture}

U

SUALLY the best effects are obtained by planting Perennials in groups of not less than three. A few of the more robust Perennials, such as the Peony or Dicentra spectabilis are effective as individual specimens. The area being planted will determine the size of the groupings.

Most Perennials may be planted in early Spring, from the time the frost is out of the ground until late June, or from the middle of September to the first of November.

For the new bed, spade to a depth of $11 / 2$ feet, and incorporate a generous supply of well decayed manure with an application of bonemeal.

Old beds should be renewed every three years. Plants should be taken out of the ground and divided. The bed should be spaded up, fertilized, and the plants returned.

While Perennials grow in poor soil, yearly fertilizing will insure fine, sturdy plants, and constant cutting of the flowers, continuous bloom. A careful selection of an assortment of varieties, and a little attention will reward you with bloom from early Spring until very late Fall.

\section{"And, ob my garden speaks the love Of upward reaching things}

Whose magic in the sunshine gives

My soul the sense of wings."

Abbreviations: Suitable for Rock Gardens (R). Suitable for Seashore (S). Attracts Birds (B).

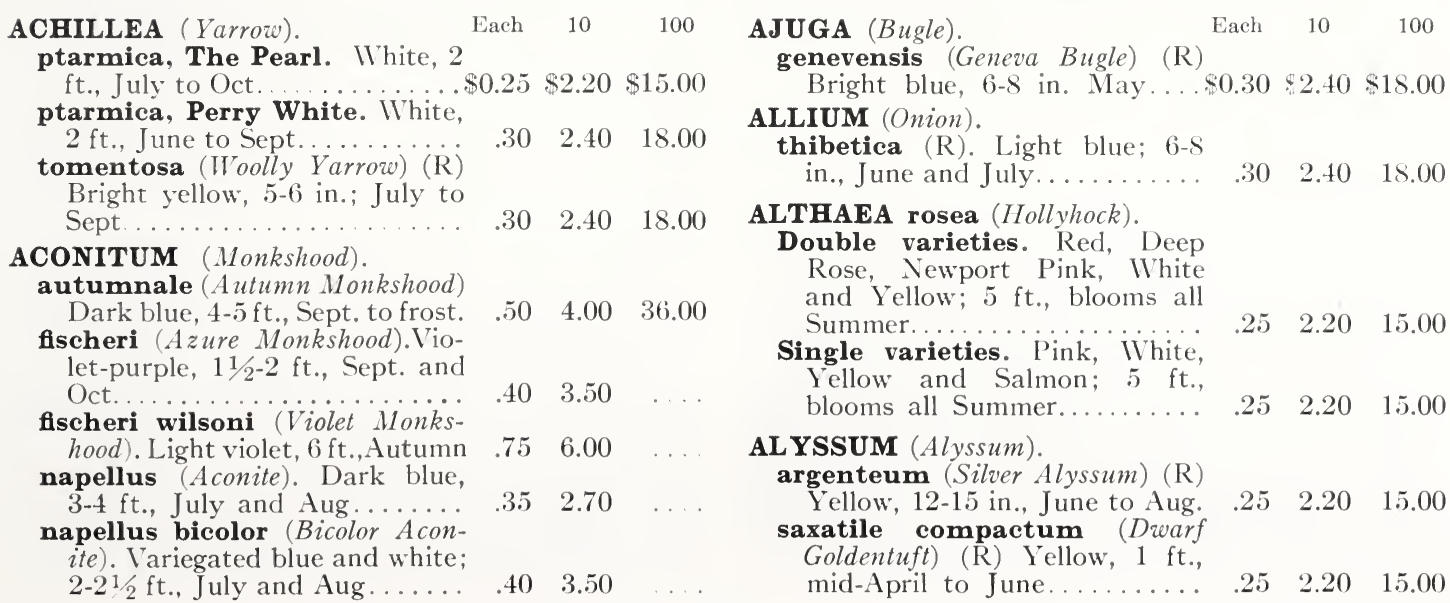




\section{ANCHUSA (Bugloss). \\ Italica Dropmore (Dropmore \\ Bugloss). Blue, 4-5 ft., June.\$0.30 $\$ 2.40 \$ 1 \$ .00$ myosotidiflora (Siberian Bugloss) \\ Pale blue, 10-12 in., April and May. \\ $.35 \quad 2.70$ \\ ANEMONE (Anemone). \\ japonica (Japanese Anemone). Rosy' red, 2 ft., Fall \\ japonica alba (White Japanese Anemone). White, 2-3 ft., Aug. and Sept. \\ japonica, Queen Charlotte. Semi-double deep pink, $3 \mathrm{ft}$., Sept, and Oct. \\ japonica rubra (Red Japanese Anemone). Rose, 2-3 ft., Aug. and Sept. \\ japonica, Whirlwind. Semi- double white, $3 \mathrm{ft}$., Sept. and Oct. \\ sylvestris (Snowdrop Anemone). (R) Cream white, 12-15 in. April to July. \\ AQUILEGIA (Columbine). \\ canadensis (American Colum bine) (R) Scarlet and yellow, $2 \mathrm{ft}$., May and June. \\ chrysantha (Golden Columbine). Yellow, $3 \mathrm{ft}$., June to Aug \\ Long-spurred Hybrids (R) Red, blue and yellow, 2-3 ft., May to to Aug. \\ vulgaris (European Columbine) All shades of blue, red, white and purple, $2 \mathrm{ft}$., May to July. \\ ARABIS (Rockcress) \\ albida fl. pl. (Double-flowered Wallcress) (R) White, 6-9 in., May \\ alpina (Alpine Rockcress) (R) White, 9 in. April and May. \\ alpina nana compacta (Dwarf Alpine Rockcress) (R) White. 6 in., April and May.......... \\ ARENARIA (Sandwort). \\ montana (Mountain Sandwort). \\ White, 4-6 in., May and June. \\ verna caespitosa (Moss Sand- wort) (R). White, 1-3 in.. June. \\ $\begin{array}{lll}30 & 2.40 \quad 15.00\end{array}$ \\ $\begin{array}{lll}.30 & 2.40 & 18.00\end{array}$ \\ $\begin{array}{lll}30 & 2.40 & 18.00\end{array}$ \\ $\begin{array}{lll}30 & 2.40 & 18.00\end{array}$ \\ $\begin{array}{lll}30 & 2.40 & 18.00\end{array}$ \\ $\begin{array}{lll}30 & 2.40 & 18.00\end{array}$ \\ $\begin{array}{lll}.25 & 2.20 & 15.00\end{array}$ \\ $\begin{array}{lll}.30 & 2.40 & 18.00\end{array}$ \\ $\begin{array}{lll}30 & 2.40 & 18.00\end{array}$ \\ $.25 \quad 2.20 \quad 15.00$ \\ $.35 \quad 3.00 \quad 24.00$ \\ $\begin{array}{lll}.25 & 2.20 & 15.00\end{array}$ \\ $\begin{array}{lll}.30 & 2.40 & 18.00\end{array}$ \\ $\begin{array}{lll}.30 & 2.40 & 18.00\end{array}$ \\ $.35 \quad 2.70$}

\section{PERENNIAL SPECIAL OFFER}

Any 5, lots of 3 each-25c. Perennials15 plants for. .

Any 5, lots of 3

15 plants for.

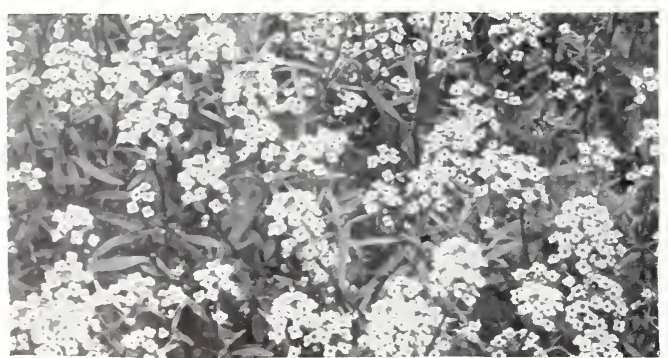

Alyssum saxatile compactum (Dwarf Goldentuft) See page 27

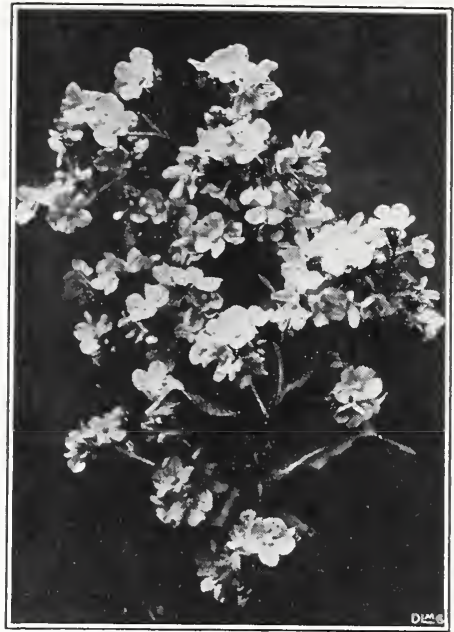

Anchusa italica, Dropmore (Dropmore Bugloss)

ARMERIA (Thrift), see STATICE

ARTEMESIA (Wormwood).

Each $\quad 10 \quad 100$

abrotanum (Southernwood). Inconspicuous flowers, 3-4 ft., Aug. and Sept............. \$0.50 \$4.50

lactiflora (White Mugwort). White, 3-4 ft., Aug. and Sept..........

Silver King (Ghost Plant). Silvery leaves and sprays of mistlike flowers, $3 \mathrm{ft}$., July.......

ASCLEPIAS (Milkweed).

tuberosa (Butterflyweed). Orange, 18-24 in., July to Sept.......

ASTER (Aster).

alpinus (Rock Aster) (R) Blue, 9 in., May and June........

alpinus giganteus. Blue, 12 15 in ................ Blue, $3-4$ ft., early Fall..............

Mauve Cushion. Delicate mauve, 9 in., Oct. and Nov..........

novae-angliae (New England Aster). Violet-purple; 3-5 ft., Aug. and Sept. .................
$.35 \quad 2.70 \quad \ldots$.

$.30 \quad 2.40 \$ 18.00$

$.35 \quad 2.70 \quad \ldots$

$.25 \quad 2.20 \quad 15.00$

$.25 \quad 2.20 \quad 15.00$

$.25 \quad 2.20 \quad 15.00$

$\begin{array}{lll}.30 & 2.40 & 18.00\end{array}$

$\begin{array}{lll}.25 & 2.20 \quad 15.00\end{array}$

\section{NAMED HARDY ASTERS}

Each $10 \quad 100$

Climax. Light lavender-blue; $5 \mathrm{ft}$., Aug. to Oct................. \$0.30 \$2.40\$18.00

Pink Perfection. Pink, 3-4 ft., Aug. to Oct................

$\begin{array}{lll}.30 & 2.40 & 18.00\end{array}$

ASTILBE (Astilbe).

Gloria. Deep pink, $2 \mathrm{ft}$., July and

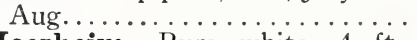
Moerheim. Pure white, $4 \mathrm{ft}$. July and Aug...............

Rose Pearl. Shell pink, $21 / 2 \mathrm{ft}$., July and Aug................. Salland. Red, $6 \mathrm{ft}$., July and Aug.
astilboides (Goatsbeard Astilbe). White, 2-3 ft.

davidi (David Asiilbe). Pink, 5 ft., July and Aug............. japonica (Japanese A stilbe). White, $1 \mathrm{ft}$., June and July....
$40 \quad 3.50 \quad \ldots$.

$\begin{array}{lll}.50 & 4.00 \quad 36.00\end{array}$

$.40 \quad 3.50$

$.35 \quad 2.70 \quad \ldots$.

$\begin{array}{lll}.50 & 4.00 \quad 36.00\end{array}$

$.35 \quad 2.70 \quad \ldots$. $\begin{array}{lll}.50 & 4.00 \quad 36.00\end{array}$ 


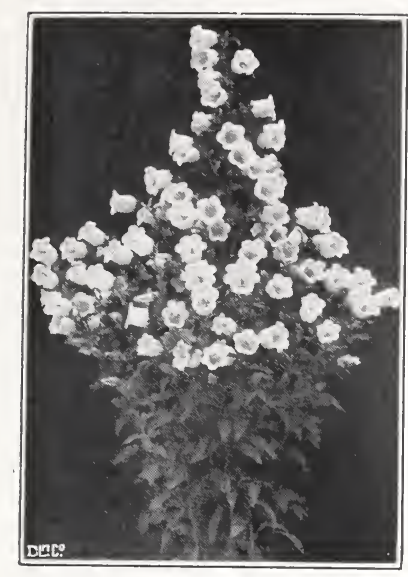

Campanula medium (Canterbury-bell)

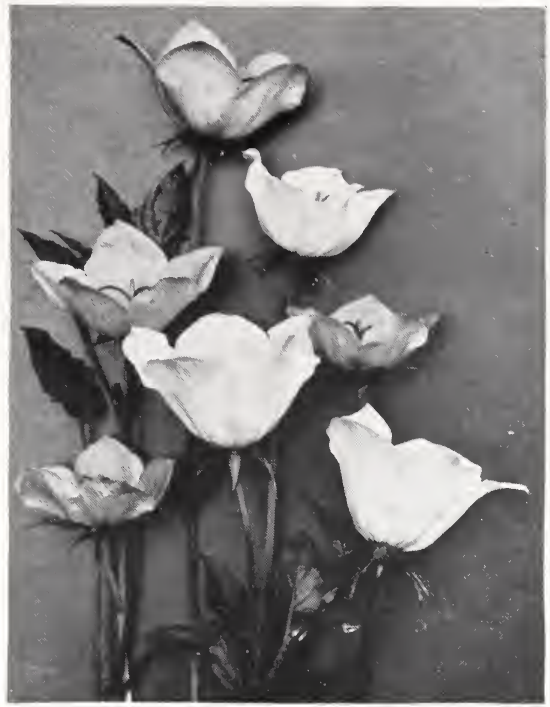

Campanula carpatica (Carpathian Bellflower)

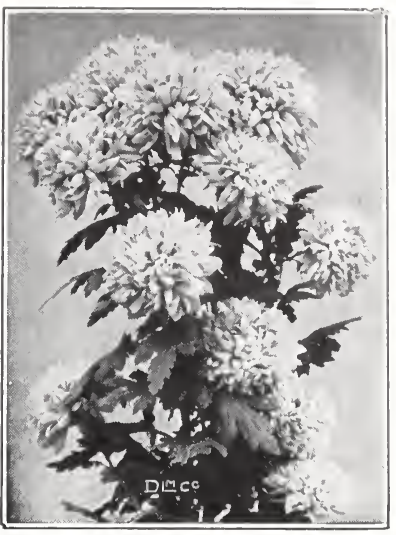

Hardy Chrysanthemums. See page 30

\section{ASTILBE-Continued}

japonica varieties:

Peach Blossom. Soft pink,

15-1S in., July and Aug. ...\$0.40 \$3.50

Queen Alexandra. Creamy pink, $2 \mathrm{ft}$., June..........

W. E. Gladstone. Pure white $2 \mathrm{ft}$. June and July........

AUBRIETIA (Aubrietia).

deltoides (Common Aubrietia) (R) Purple, 3-4 in., April and

May.................

BAPTISIA ( Wild-indigo).

australis (Blue Wild-indigo). Deep blue, 2-3 ft., May and June..................... tinctoria (Yellow Wild-indigo) Yellow, 2-3 ft., July. .

BELLIS (English Daisy).

perennis (English Daisy). Red, white and pink, 3-6 in., April June................

BOLTONIA (Boltonia).

asteroides (White Boltonia). White, 5-6 ft., Sept. and Oct.

laevigata. Pink, fading to white, 6-7 ft., Oct.

latisquama (Violet Boltonia). Violet, $4 \mathrm{ft}$., July to Oct. .

CALLIRHOE ( $P o p p y-m a l l o w)$.

involucrata (Low Poppy-mallow) (R) Cherry-red, 9-12 in.; all Summer.

CAMPANULA (Bellflower).

alliariaefolia (Spurred Bellflower) (R) White, 11/2-2 ft., July..

carpatica (Carpathian Bellflower) (R) Dark blue, 9 in., June to Oct.

$.40 \quad 3.50$

$.50 \quad 4.00 \$ 36.00$

$.35 \quad 2.70$

$\begin{array}{lll}30 & 2.40 \quad 18.00\end{array}$

$.25 \quad 2.20 \quad 15.00$

$.25 \quad 2.20 \quad 15.00$

$.25 \quad 2.20 \quad 15.00$

carpatica alba (White Carpathian Bellflower). Pure white, 9 in., June to Sept.

garganica (Gargano Harebell) (R) Blue, 3-4 in., June to Sept. . . . .

\section{CAMPANULA - Continued}

medium (Canterbury-bell). Pink, blue, white and mixed, 2-3 ft. June and July............ medium calycanthema (Cup
saucer Bellflower). Pink, blue white, and mixed, 2-3 ft., July. persicifolia (Peachleaf Bellflower). Blue, 2-3 ft., June to July. . rotundifolia (Harebell) (R) Blue, $1 \mathrm{ft} .$, June to Aug............ .

CAREX (Sedge).

morrowi variegata (Silveredge Morrow Sedge) (R) Grasslike plant, $1 \mathrm{ft}$.

Each $\quad 10 \quad 100$

$\$ 0.30 \$ 2.40 \$ 18.00$

$\begin{array}{lll}.30 & 2.40 & 18.00\end{array}$

$\begin{array}{lll}30 & 2.40 & 18.00\end{array}$

$\begin{array}{lll}30 & 2.40 \quad 18.00\end{array}$

CENTAUREA (Centaurea).

montana (Mountain-bluet) (R) Bluish-violet, 20 in., July to

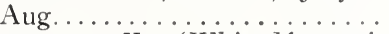
montana alba (White Mountainbluet) (R) White form of the

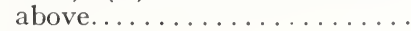

CERASTIUM (Cerastium). tomentosum (Snow-in-summer) (R) White, 3-6 in., May and
$.25 \quad 2.20 \quad 15.00$

$25 \quad 2.20 \quad 15.00$

$\begin{array}{lll}.30 & 2.40 \quad 18.00\end{array}$

$40 \quad 3.50$

$\begin{array}{lll}30 & 2.40 & 18.00\end{array}$ June. .

-

plumbaginoides (Larpente plumbago) (R) Blue, 6-8 in., May to Sept. .............................

allioni (Wallflower) (R) Orangeyellow, 6-12 in., May to July.

CHRYSANTHEMUM (Chrysanthmum) (Also see Pyrethrum)

coreanum (Korean Chrysanthemum) (R) Rose pink, 2-3 ft.,

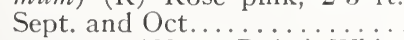

maximum (Shasta Daisy). White, $21 / 2 \mathrm{ft}$., July to Oct.

$\begin{array}{lll}.30 & 2.40 \quad 18.00\end{array}$

$.35 \quad 2.70$ maximum, Burbank's Frilled. New variety, large white flowers, $2 \mathrm{ft}$., July to Sept. . $\begin{array}{lll}.30 & 2.40 \quad 18.00\end{array}$

$.30 \quad 2.40 \quad 18.00$

$\begin{array}{lll}.25 & 2.20 & 15.00\end{array}$

$.35 \quad 2.70$

$\begin{array}{lll}.30 & 2.40 \quad 18.00\end{array}$

$.35 \quad 2.70$

$.25 \quad 2.20$

.75 


\section{CHRYSANTHEMUMS Continued}

\section{NAMED HARDY CHRYSANTHEMUMS}

Baby. Button type; yellow; late Each $10 \quad 100$ flowering .................... $80 \$ 2.40 \$ 18.00$

Boston. (iolden bronze, Oct, and
Barbara Cumming. Large flowering, yellow, orange-brown center.

Field of Snow. Large pure white.

Fred Peele. Yellow bronze button

Glory of Seven Oaks. Golden yellow.

Golden Pheasant. Orange vellow. Gypsy Girl. Bright crimson...

Harvest Moon. Golden yellow.

Lilian Doty. Soft pink.

Mrs. Calvin Coolidge. Cardina red, large, single, early

Mrs. William Buckingham. Single, salmon-pink

Red Doty. Double wine-red

Rose Gem. Rose-pink

Ruth Hatton. Clear ivory-white Pompon.

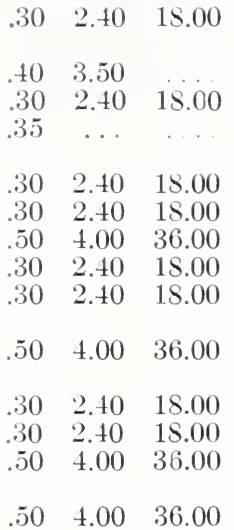

CIMICIFUGA (Bugbane). racemosa (Cohosh Bugbane). White, 4-6 ft., July to Sept.

\section{CLEMATIS (Clematis) (See Vines} also).

heracleaefolia davidiana (Fragrant Tube Clematis). Pale blue, $3 \mathrm{ft}$., Aug. and Sept.

integrifolia. Blue, $2 \mathrm{ft}$., June to Aug recta (Ground Clematis). White, $2-3 \mathrm{ft}$

CONVALLARIA (Lily-of-the-valley). majalis. White, 8 in., May.

Clumps

Strong pips.

COREOPSIS (Coreopsis)

grandiflora (Big Coreopsis). Yellow, 2-3 ft. Nay to Nov.

lanceolata (Lance Coreopsis). Yellow, 2 ft., June to Sept.

DELPHINIUM (Larkspur).

belladonna. Pale blue, $3-4 \mathrm{ft}$. June and July...

bellamosum. Dark blue form of Belladonna, 3-4 ft., June and July

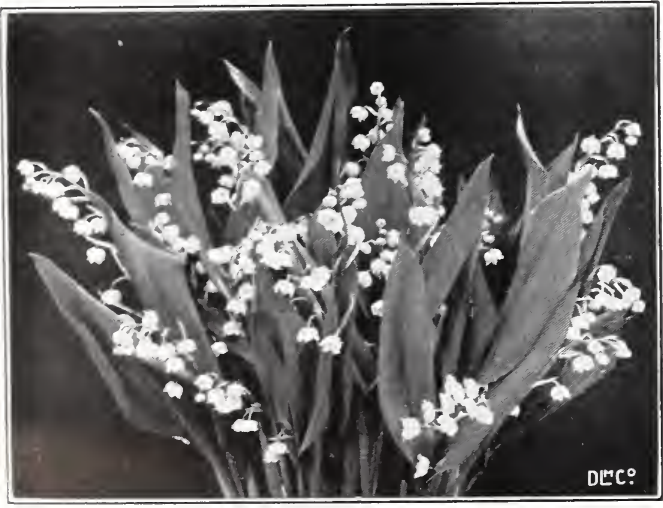

Convallaria majalis (Lily-of-the-zalley)

$50 \quad 4.50 \quad 40.00$

$15 \quad 1.00 \quad 7.50$

$.25 \quad 2.20 \quad 15.00$

$\begin{array}{lll}.25 & 2.20 & 15.00\end{array}$

$\begin{array}{lll}.30 & 2.40 & 18.00\end{array}$

$\begin{array}{lll}30 & 2.40 & 18.00\end{array}$

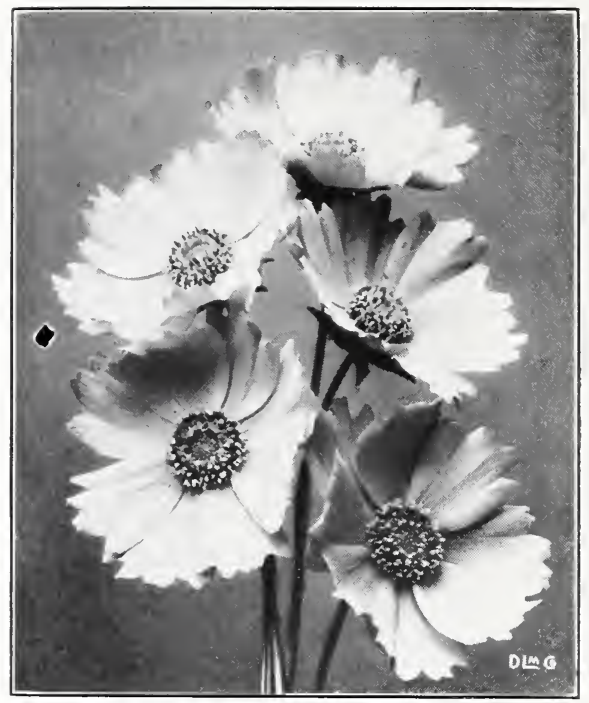

Coreopsis grandiflora (Big Coreopsis)

DELPHINIUM - Continued

Blackmore \& Langdon Hy- Each 10100 brids. Blue, lavender, violet and mauve, 4-5 ft., June and July. .................\$0.50 \$4.00\$36.00

Hybrids. Mixed colors, 2-21/2 ft., June and July.

$\begin{array}{lll}35 & 3.00 & 24.00\end{array}$

grandiflorum chinense (Slender Larkspur). All shades of blue, 2-3 ft., June to Aug....

$\begin{array}{lll}30 & 2.40 & 18.00\end{array}$

\section{DIANTHUS (Pink).}

alpinus ( $R$ ) Rose-pink, 3 in., June and July.............

allwoodi (Allwood's Pinks). White, pink and crimson, 1215 in., May to Oct...........

var. Beatrix. Salmon-pink, 9-12 in., May and July............

barbatus (Sweet-william). Pink, red and white, 10-20 in., June and July.........................

caesius (Cheddar Pink) (R) Pink, 3-6 in., May to July..........

deltoides (Maiden Pink) (R) Dark red, 6 in., June and July.

deltoides alba (White Maiden Pink) (R) White, 6 in., June

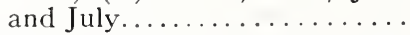

plumarius (Grass Pink). Pink, white and purplish, 9-12 in., June..................

$\begin{array}{lll}50 & 4.00 \quad 36.00\end{array}$

$\begin{array}{lll}.30 & 2.40 & 18.00\end{array}$

$.25 \quad 2.20 \quad 15.00$

$\begin{array}{lll}30 & 2.40 & 18.00\end{array}$

$\begin{array}{lll}30 & 2.40 & 18.00\end{array}$

$\begin{array}{lll}.30 & 2.40 & 18.00\end{array}$

$\begin{array}{lll}.25 & 2.20 & 15.00\end{array}$ $\begin{array}{lll}35 & 3.00 & 24.00\end{array}$

\section{NAMED HARDY PINKS}

Lord Lyons (R) Pink, 8-10 in., June and July. ............... . . . . $2.40 \quad 18.00$

Rose de May (R) Delicate pink, $9-15$ in., all Summer......... . . 30 $2.40 \quad 18.00$

Furst Bismarck. Pink, 8-12 in., all Summer................. .35 $3.00 \quad 24.00$ 
DICENTRA (Bleedingheart).

Each $\quad 10 \quad 100$

eximea (Fringed Bleedingheart)

(R) Rose, 12 in., all Summer. .\$0.35 \$2.70

formosa (Western Bleedingheart)

(R). Pink, 15 in., April to Aug. .352 .70

spectabilis (Bleedingheart). Rosy

red, 24 in., April to July......

$60 \quad 5.00 \$ 40.00$

DICTAMNUS (Gasplant)

albus (White Gasplant). White,

$2-3 \mathrm{ft} .$, June and July. .......

alba caucasicus (Giant Gas-

plant). White, 3-4 ft., June and

July. . . . . . . . .

DIGITALIS (Foxglove).

ambigua (Yellow Foxglove). Yel-

low, 2-3 ft., June to July.

purpurea (Common Foxglove). Purple, 2-3 ft., July to Sept. purpurea alba (Common White Foxglove). White, 2-3 ft., July to Sept.

purpurea gloxinaeflora (Gloxinia Foxglove). White to purple, 3-4 ft., June and July.

purpurea gloxinaeflora rosea Rose, 2-3 ft., June and July.

Shirley Hybrids. White to rosepurple, $5-7 \mathrm{ft}$.

DORONICUM (Leopardbane).

clusi (Downy Leopardbane). Yellow, $2 \mathrm{ft}$., June and July...

DRABA (Whitlowgrass).

fladnizensis (Arctic Whitlowgrass) (R) Yellow, 3 in., April .

ECHINACEA (Hedgehog-Coneflower) purpurea (Purple Coneflower). Purple, 2-31/2 ft., July and Aug.

ECHINOPS (Globethistle)

pumilum (Globethistle). Blue, 3 ft., Aug. ................ ritro (Steel Globethistle). Blue, 4 ft., July and Aug...

ERIGERON (Fleabane) caucasicus (R) Violet, yellow center, 12 in., June and July.

ERYSIMUM (Blistercress). pulchellum (RockeryBlistercress) (R) Orange-yellow, 6-12 in., May and June.

EUPATORIUM (Eupatorium). coelestinum (Mistflower). Lavender-blue, 18-24 in., Aug. to Oct.

urticaefolium (ageratoides) (Snow Thoroughwort). White, 2-3 ft., Aug. to Sept.

EUPHORBIA (Spurge). corollata (Flowering Spurge). White, 18 in., July and Aug..

\section{HARDY FERNS}

ADIANTUM pedatum (American Maidenhair Fern) (R) Fanlike foliage, $12-15$ in ...........

POLYSTICHUM acrostichoides (Christmas Fern) (R) Evergreen,
$.40 \quad 3.50$

$45 \quad 4.00$

$\begin{array}{lll}30 & 2.40 & 18.00\end{array}$

$\begin{array}{lll}30 & 2.40 & 18.00\end{array}$

$\begin{array}{lll}30 & 2.40 & 15.00\end{array}$

$\begin{array}{lll}30 & 2.40 & 18.00\end{array}$

$\begin{array}{lll}.30 & 2.40 & 18.00\end{array}$

$.35 \quad 3.00 \quad 24.00$

$.50 \quad 4.50$

$.50 \quad 4.50$

$\begin{array}{lll}.30 & 2.40 & 18.00\end{array}$

$25 \quad 2.20 \quad 15.00$

$\begin{array}{lll}30 & 2.40 & 18.00\end{array}$

$.50 \quad 4.00 \quad 36.00$

$.35 \quad 2.70$

$.25 \quad 2.20 \quad 15.00$

$\begin{array}{lll}30 & 2.40 \quad 18.00\end{array}$

$\begin{array}{lll}30 & 2.40 & 18.00\end{array}$ $\begin{array}{lll}30 & 2.40 & 18.00\end{array}$

$35 \quad 2.70$

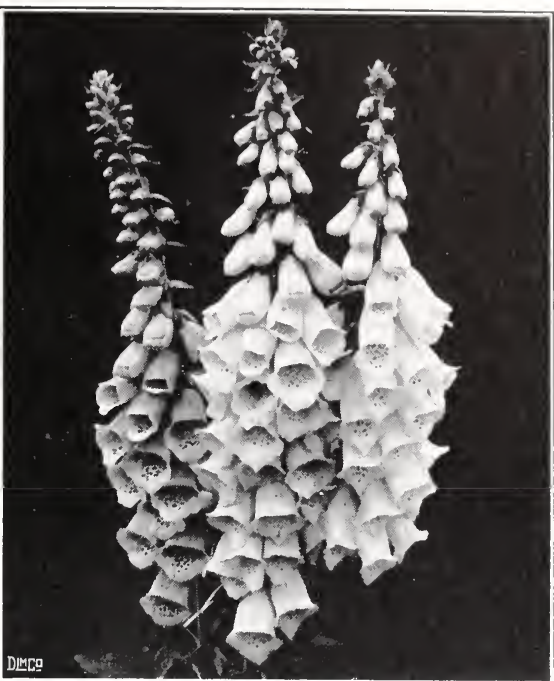

Digitalis

Each $\quad 10 \quad 100$

FESTUCA (Fescue)

glauca (Blue Fescue) (R) Blue

foliage, $10-12$ in . . . . . . . \$ $\$ 0.30 \$ 2.40 \$ 1 \$ .00$

FILIPENDULA (Meadowsweet).

camtschatica (Spiraea gigantea)

(Kamchatka Meadowsweet).

White, 5-6 ft., July.

hexapetala (Spiraea filipendula) (Dropwort) (R) White, 2-3 ft. June and July...

hexapetala flore-pleno (Double Dropwort) (R) Double white

$12-15$ in., June and July.

$30 \quad 2.40 \quad 18.00$

$\begin{array}{lll}30 & 2.40 & 18.00\end{array}$

$\begin{array}{lll}30 & 2.40 & 18.00\end{array}$

FUNKIA (Plantainlily), sec Hosta.

GAILLARDIA (Gaillardia).

aristata grandiflora. Dark crimson and gold, $2 \mathrm{ft}$., July to frost. aristata maxima. Crimson and yellow, $2 \mathrm{ft}$., July to frost.

$\begin{array}{lll}25 & 2.20 & 15.00\end{array}$

$\begin{array}{lll}.25 & 2.20 & 15.00\end{array}$

GALIUM (Bedstraw).

verum (Yellow Bedstraw) ( $\mathrm{R}$ ) Yellow.

GERANIUM (Cranesbill)

sanguineum (Bloodred Cranesbill)

(R) Blood-red, 18 in., May to

Oct.

$\begin{array}{lll}30 & 2.40 & 18.00\end{array}$

GEUM (Avens)

chiloense atrosanguineum (Double Crimson Geum). Dark red, $1-1 \frac{1}{2} \mathrm{ft}$., May to July. .

chiloense, Mrs. Bradshaw. Scarlet, 12-15 in., June to Sept.

Lady Strathedon (R) Golden vellow, 18 in., June to Sept.

$.50 \quad 4.00 \quad 36.00$

$30 \quad 2.40 \quad 18.00$

$35 \quad 3.00 \quad 24.00$

$\begin{array}{lll}35 & 3.00 \quad 24.00\end{array}$

\section{PERENNIAL SPECIAL OFFER}

Any Five, lots of 3 each-25c. Perennials -15 plants for

Any Five, lots of 3 each -30c. Perennials 15 plants for.

Any Five, lots of 3 each-35c. Perennials 15 plants for

3.95 


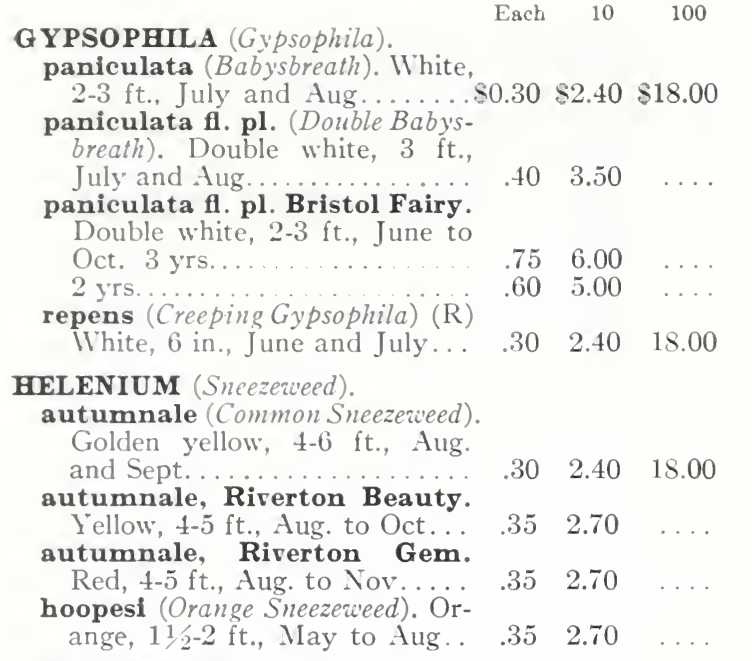

HELIANTHEMUM (Sunrose).

halimifolium multiflorum (Horocco Sunrose) (R) Orange pink, 4-6 in., June to Sept. .

HELIANTHUS (Sunflower).

decapetalus (Thinleaf Sunflower). Yellow, 4-5 ft., Aug. to Oct... mollis (Ashy Sunflower). Lemon yellow, 3-1 ft., July to Sept. .

HEMEROCALLIS (Daylily).

flava (Lemon Daylily). Bright yellow, $3 \mathrm{ft} .$, May and June.....

fulva (Tawny Daylily). Dusty orange, 2-3 ft., June and July..

middendorfi (Amur Daylily). Golden orange, 2-3 ft., June and July. .

thunbergi (Japanese Daylily). Buttercup yellow, $3 \mathrm{ft}$., July.

\section{BETSCHER'S HYBRID HEMEROCALLIS}

Bay State. Deep yellow, $21 / 2 \mathrm{ft}$., July and Aug............. 2.0018 .00

Mrs. W. H. Wyman. Pale lemon-

yellow, $2 \frac{1}{2} \mathrm{ft}$., July and Aug. . . 2.0018 .00

HERNIARIA (Burstwort).

glabra (Burstwort) (R) Greenish, inconspicuous flowers, 2 in., July and Aug. . . .

$.40 \quad 3.50$

HESPERIS (Rocket)

matronalis (Dames Rocket) ( $\mathrm{R}$ ) Purple, 2-3 ft., June and July.

\section{HEUCHERA (Alumroot).}

sanguinea (Coralbells) (R) Coral, 12-18 in., June to Sept.........

sanguinea alba (White Coralbells) (R) White, 12-18 in., June to Sept..............

Grenadin Scarlet (R) Scarlet.

Perry's White (R) White, 1-2 $\mathrm{ft}$., Nay to Sept.

Shirley Hybrids (R) Deep rose, $2 \mathrm{ft}$., June to Sept..........

HIBISCUS (Rosemallow).

moscheutos (Common Rosemallorv). Rose-red, 3-4 ft., Aug. and Sept. .

\section{$.40 \quad 3.00 \quad 24.00$}

$.25 \quad 2.20 \quad 15.00$

$\begin{array}{lll}.30 & 2.40 & 18.00\end{array}$

$\begin{array}{lll}.30 & 2.40 & 18.00\end{array}$

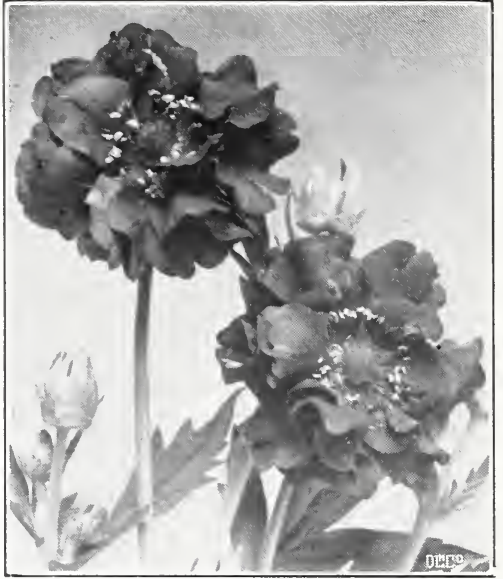

Geum, Mrs. Bradshaw. See page 31

Each 10

100

HOSTA (Plantainlily)

caerulea (Blue Plantainlily). Blue,

$1-2 \mathrm{ft}$., July and Aug........\$0.30 \$2.40 \$18.00

lancifolia undulata variegata (Wavyleaf Plantainlily). Blue,

$1 \mathrm{ft} .$, June and July......... $\quad .30 \quad 2.40 \quad 18.00$

HYPERICUM (St. Johnswort).

repens (R) Yellow, 4-6 in., Aug................ .40 $3.50 \quad \ldots$.

HYSSOPUS (Hyssop).

officinalis (Hyssop) (R) Purple, 1-2 ft., June to Aug.......... officinalis rosea ( $R$ ) Pink, 1-2

$\mathrm{ft}$., June to Aug............

$\begin{array}{lll}.30 & 2.40 & 18.00\end{array}$

$\begin{array}{lll}.30 & 2.40 & 18.00\end{array}$

IBERIS (Candytuft).

gibraltarica (Gibraltar Candytuft) (R) White, 8 in., May and

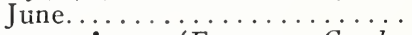
sempervirens (Evergreen Candy. tuft) (R) White, $1 \mathrm{ft}$. May... sempervirens, Little Gem (R) White, 6 in., May..........

$\begin{array}{lll}.30 & 2.40 & 18.00\end{array}$

$\begin{array}{lll}.30 & 2.40 & 18.00\end{array}$

$\begin{array}{lll}.30 & 2.40 & 18.00\end{array}$

\section{IRIS}

ALPINE (Early Flowering) (R)

Lobelia. Blue, 6-9 in., March

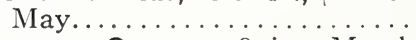

Orange Queen. 9 in., March May............................. used: S. for standards, or upper petals; F. for Falls, or lower petals.

GERMAN (Tall Bearded).

Afterglow (Sturtevant 1917) (83$82) 36$ in. Very lovely soft blend, as difficult to describe as the evening sunset, from which it derives its name.....

Alcazar (Vilmorin 1910) (86-87) 42 in. Fragrant. S. soft violet to orchid of a glistening silky texture; $F$. rich velvety crimson-purple, with white throat, heavily veined bronze. Bright orange beard and amber style arms. Rated one of the best ten by the Cornell Test Gardens

$\begin{array}{lll}.50 & \ldots & \ldots \\ .50 & \ldots & \ldots\end{array}$

$.50 \quad 4.20 \quad 36.00$

$\begin{array}{lll}.40 & 3.30 & 27.00\end{array}$ 
Archeveque (Vilmorin 1911) (8.3) 24 in.; S. purple-violet; F. deep velvety violet............ \$0.50 $\$ 4.20 \$ 39.00$

Aphrodite (Dykes 1922) (81-88) 44 in. Sweetly fragrant; one of the best and tallest pinktoned varieties. Soft, bright, with pleasing white flush in throat. Sold for $\$ 50$ about six years ago and is still quite rare 1.75

Ballerine (Vilmorin 1920) (90-89) 48 in. Fragrant, late; one of the best light blue toned varieties. Free flowering, with a gigantic flower of fine form...

Cecil Minturn (Farr 1922) (7981) 30 in. Late, fragrant, large flowers of exquisite uniform soft Cattleya rose. S. ruffled.

Col. Candelot (Millet 1907) (7678) 30 in. Late, rich coloring, with rosy bronze standards; rich velvety crimson maroon falls and old gold styles.

Dream (Sturtevant 1918) (84. 84) 38 in. Late; a "dream" of a soft, clear uniform pink-toned Iris.

Edouard Michel (Verdier 1904) (78-81) 30 in. Very fragrant; brilliant red tone. .

Eldorado (Vilmorin 1910) (7.8) 30 in. S. bronzy yellow, stained mauve; $F$. violet and yellow

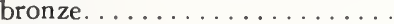

Esplendido (Mohr 1924) (83-86) 42 in. Fine, large, bright redpurple bicolor. One of the richest and finest of this type. Rugged and free flowering.......

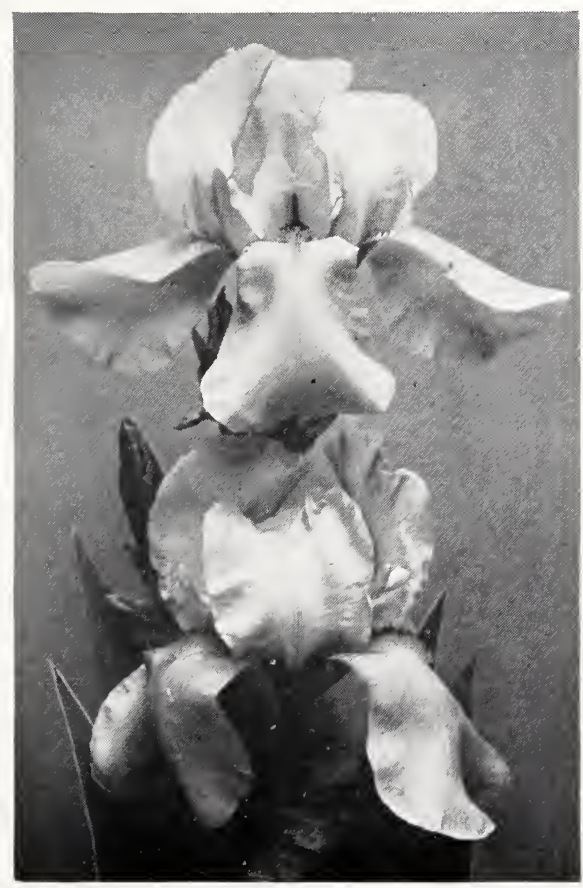

German Iris
Horatius. S. buff, shaded blue; F. blue, veined deeper blue and chocolate..............

Isoline (Vilmorin 1904) (83-84) 36 in. Fragrant; one of the old popular varieties. S. very large, delicate lilac - rose coloring, slightly tinged yellow; $F$. purple old rose, with deep golden veins at the throat over a light orange and cream ground. .

$\begin{array}{lll}25 & 2.10 & 15.00\end{array}$

Lent A. Williamson (Williamson 1918) (88-88) 44 in. $S$. soft Campanula violet; $F$. velvety Pansy violet. Rich golden beard and blending of yellow at throat. One of the very finest Irises...........................

Lord of June (Yeld 1911) (88-78) 40 in. Fragrant; S. soft lavender blue; F. rich violet blue. Very large flowers, with a delightful cinnamon fragrance..........

Magnifica (Vilmorin 1920) (87$85) 42$ in. Fragrant. A brilliant crimson toned bicolor. One of the finest Irises in cultivation.

Morning Splendor (Shull 1923) (91-91) 36 in. Fragrant, late. Very large flowers of a rich red tone and perfectly formed. Recognized as the finest American Iris introduced to date...

\section{Mother of Pearl (Sturtevant} 1921) (84-84) 44 in.; late. This flower has an iridescent Motherof-Pearl coloring, with a white throat overlaid with gold....

Parc De Neuilly (Verdier 1910) (8.1) 30 in.; flowers rich plumpurple; S. arching;

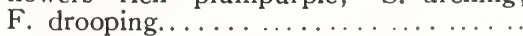

Roseway (Bliss 1919) (74-78) 36 in.; late, handsome uniform deep old rose color Seminole (Farr 1920) (83-83) 30 in., late. A very rich velvety crimson bicolor......

Shekinah (Sturtevant 1918) (84-84) 36 in.; fragrant. A handsome clear soft yellow with a little deeper color at the throat and a handsome golden beard. One of the very few good yellow varieties......

Souvenir de Mme. Gaudichau (Millet 1914) (91-88) 40 in.; fragrant. This is the largest, darkest, and finest of the dark purple Irises. Even the beard has a bluish cast.

Valencia (Mohr. 1926) (85-86). S. erect, ruffled, of a uniform buff shade; F. same color, with a slight tinge of violet towards center of petals; throat veined a deeper

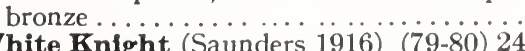

White Knight (Saunders 1916) $(79-80) 24$
in.; fragrant. Beautiful snow-white flowers of waxy texture. A very fine white..
PERENNIAL SPECIAL OFFER

Any Five, lots of 3 each-25c. Perennials-15 plants for $\$ 2.95$ Any Five, lots of 3 each-30c. Perennials-15 plants for $\mathbf{3 . 4 5}$ Any Five, lots of 3 each-35c. Perennials-15 plants for 3.95 
IRIS Continued

Each $\quad 10 \quad 100$

KAEMPFERI (Japanese), Flowers

in middle July; $3 \mathrm{ft} \ldots . . . .5()$

Alida. White, striped in light blue

Helen ron Siebold. Deep pink, white lines

Mahogany. Dark red, shaded maroon.

Neptune. Violet, overlaid with dark blue

Paragon. Purple, Purple and gold

\section{MISCELLANEOUS IRIS}

Pumila cyanea ( $R$ ). Deep blue, dwarf, April

sibirica (Siberian Iris). Pale blue, $3 \mathrm{ft}$.. June

JASIONE (Sheeps-bit).

perennis (Sheeps-bit) (R) Blue, 6-12 in., July and Aug.

KNIPHOFIA (Torchlily).

uraria grandiflora (Dayglow Torchlily). Red, 3-4 ft., Aug. to October

uraria pfitzeriana (Bonfire Torchlily.). Orange-scarlet, 2-3 ft., Aug. to Oct

tucki (Tuck Torchlily). Orangescarlet, 2-3 ft., Aug. to Oct.

LATHYRUS $P e a)$.

latifolius Perennial Pea). Rosy red, $4 \mathrm{ft}$., July to Sept.

Mixed

LAVANDULA (Lavender)

officinalis (vera) (TrueLavender). Blue, $1^{1} / 2 \mathrm{ft}$., July and Aug. .

LIATRIS (Gay'feather).

pycnostachya (CattailGayfeather) Pale purple, 3-5 $\mathrm{ft}$., Aug. to Oct. scariosa. Dark lavender, 2-3 ft., Aug. to Sept.

spicata (Spike Gavfeather). Rosy purple, $2-3 \mathrm{ft}$., July to Sept.

LIGULARIA (Groundsel).

clivorum (Senecio clivorum) (Ragweed). Yellow, $4 \mathrm{ft}$., June to Aug.

\section{LILIUM (Lily').}

auratum (Goldband Lily). White, $3 \mathrm{ft} .$. July and Aug............ candidum MadonnaLily). White, $2-3 \mathrm{ft}$. . June and July........
elegans. Orange to deep maroon, $1 \frac{1}{2} \mathrm{ft}$., June and July

hansoni (Hanson Lily).

Apricot yellow, dotted with brown, 3-4 ft., June......... henryi (Henry Lily). Apricotorange, 6-s ft., July and Aug. .

longiflorum giganteum (Giant Lily). White, 4-5 ft., July and August

regale (Royallily). White, shaded pink, 2-3 ft., Aug

speciosum album (White Speciosum Lily). White, $3 \mathrm{ft}$., Aug. and Sept.

speciosum rubrum (Red speciosum Lily). Red, $3 \mathrm{ft}$., Aug. and Sept

tigrinum (Tiger Lily). Orangered, spotted purple, 2-5 ft., Aug.

LINUM (Flax).

flavum (Golden Flax) (R) Yellow, $1 \mathrm{ft}$., June and July.........
.35 $\quad 2.70$

$\begin{array}{lll}30 & 2.40 & 18.00\end{array}$

5) $\$ 4.00 \$ 36.00$

$.50 \quad 4.00 \quad 36.00$

$\begin{array}{lll}50 & 4.00 \quad 36.00\end{array}$

$.50 \quad+.00 \quad 36.00$

$.50 \quad+.00 \quad 36.00$

5) $4.00 \quad 36.00$

$\begin{array}{lll}.30 & 2.40 \quad 18.00\end{array}$

$\begin{array}{lll}30 & 2.40 & 18.00\end{array}$

$\begin{array}{lll}.30 & 2.40 & 18.00\end{array}$

$\begin{array}{lll}.30 & 2.40 & 18.00\end{array}$

$\begin{array}{lll}.30 & 2.40 & 18.00\end{array}$

$\begin{array}{lll}.30 & 2.40 & 18.00\end{array}$

$.35 \quad 2.70$

$\begin{array}{lll}30 & 2.40 & 18.00\end{array}$

$\begin{array}{lll}30 & 2.40 \quad 18.00\end{array}$

$\begin{array}{lll}.30 & 2.40 & 18.00\end{array}$

$\begin{array}{lll}40 & 3.50 & 25.00\end{array}$

$\begin{array}{lll}.50 & 4.00 \quad 30.00\end{array}$

$.40 \quad 3.50$

$\begin{array}{lll}.35 & 3.00 & 24.00\end{array}$

$.75 \cdot 6.00$

$.75 \quad 6.00$

$.60 \quad 5.00$

$.60 \quad 5.50$

$.50 \quad 4.40$

$\begin{array}{lll}.30 & 2.40 & 18.00\end{array}$

$.35 \quad 2.70$ $\begin{array}{lll}.40 & 3.50 \quad 25.00\end{array}$

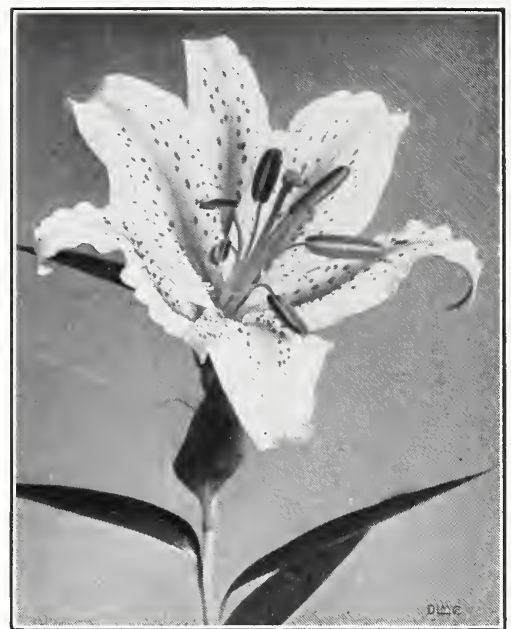

Lilium auratum (Goldband Lily)

Each $\quad 10 \quad 100$

LOBELIA (Lobelia).

cardinalis (Cardinalflower). Scar-

let, $3 \mathrm{ft}$. July and Aug. . . . . $\$ 0.30 \$ 2.40 \$ 18.00$

siphilitica (Large Blue Lobelia). Deep blue, 2-3 ft., Aug. and

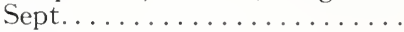

LUPINUS (Lupine).

polyphyllus (Washington Lupine). Deep blue, 2-3 ft., June to Sept.

polyphyllus albiflorus (White Washington Lupine). White, 3 ft., June to Sept.

polyphyllus moerheimi (Moerheim Lupine). Pink, 2-3 ft., June to Sept..................

polyphyllus roseum (Blush Lupine). Rosy pink, $3 \mathrm{ft}$., June to

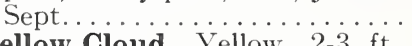

Yellow Cloud. Yellow, 2-3 ft.,

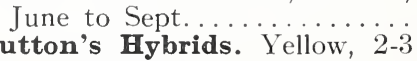
$\mathrm{ft}$. , June to Sept. ............

$\begin{array}{lll}30 & 2.40 & 18.00\end{array}$

$\begin{array}{lll}30 & 2.40 \quad 18.00\end{array}$

$\begin{array}{lll}.30 & 2.40 & 18.00\end{array}$

$35 \quad 2.70$

$.35 \quad 2.70$

$\begin{array}{lll}.35 & 3.00 \quad 24.00\end{array}$

$.35 \quad 3.00 \quad 24.00$

LYCHNIS (Campion).

alpina (Arctic Campion) (R) Reddish purple, 4 in. Aug.........

chalcedonica (Maltese Cross). Orange-scarlet, 2-3 ft., June to

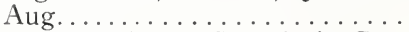
coronaria (Rose Campion). Carmine, 18 in., June and July .... viscaria splendens fl. pl. (Double Rose-pink Campion). Rosepink, 12-15 in., June and July .

LYSIMACHIA (Loosestrife)

nummularia (Moneywort) (R) Yellow, 4 in., June and July...

LYTHRUM (Lythrum).

salicaria roseum (Rose Loosestrife). Rose, 4-5 ft., July to

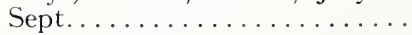

MALVA (Mallow).

alcea (Hollyhock Mallow). Pink, $2 \mathrm{ft}$., all Summer........... .30 $2.40 \quad 18.00$

MENTHA (Mint).

spicata (Spearmint). Purple, 18 in., July and Aug .......... . . . $30 \quad 2.40 \quad 18.00$ 
MERTENSIA (Bluebells) virginica (Virginia Bluebells) (R) Blue, 1-2 ft., April to June. .\$0.30 $\$ 2.40 \$ 18.00$

MONARDA (Beebalm). didyma (Oswego Beebalm). Scarlet,

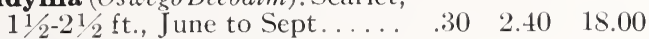

MYOSOTIS (Forget-me-not).

dissitiflora (Swiss Forget-me-not) (R) Sky-blue, 6-10 in., May to July scorpioides semperflorens (Dwarf Perpetual Forget-me-not) (R) Light blue, 8 in., June to Sept.......................

NIEREMB
rivularis (Whitecup) (R). White 6 in., June to Aug. . . . . . . .

OENOTHERA (Evening-primrose or Suntrops).

fruticosa youngi (Youngs Sundrops). Bright lemon-yellow, $2 \mathrm{ft}$., June to Aug.............
glauca fraseri (Fraser Sundrops). Yellow, $1 \mathrm{ft}$., June to Aug. missouriensis (Ozark Sundrops) (R) Bright yellow, 10 in., June to Aug. .................. speciosa. Pure white, 18 in., Aug.

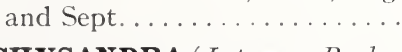

PACHYSANDRA (Japanese Pachysandra).

terminalis ( $R$ ) Ground cover, white flowers, May and June. Field grown. .

3 in. pots.

PAEONIA (Peony).

Festiva Maxima (Miellez 1851) (9.3) Waxy white with crimson markings. Early.

Karl Rosenfield (Rosenfield 1908 ) (8.8) Dark crimson, large flower. About the finest red Peony. Midseason.................. Mikado Japan 1893) (8.6) Early
blooming; deep rose variety of

great floriferousness. .......
officinalis rubra. The old-fasshioned early blooming red Peony. Large, glowing, deep crimson flowers.

Walter Faxon (Richardson) (9.3) Very brilliant glowing pink. The finest Pink Peony we know. Midseason.

PAPAVER (Poppy).

alpinum (Alpine Poppy). Yellow 6 in., June to Sept ......... nudicaule (Iceland Poppy) (R)
Orange, white, yellow, $1 \mathrm{ft}$; all summer.................... orientale (Oriental Poppy). Scarlet, 2-3 ft., May to July......
$.35 \quad 2.70$

$\begin{array}{lll}30 & 2.40 & 18.00\end{array}$

$\begin{array}{lll}30 & 2.40 & 18.00\end{array}$

\section{PERENNIAL SPECIAL OFFER}

Any 5, lots of 3 each-25c. Perennials 15 plants for. .

Any 5, lots of 3 each-30c. Perennials

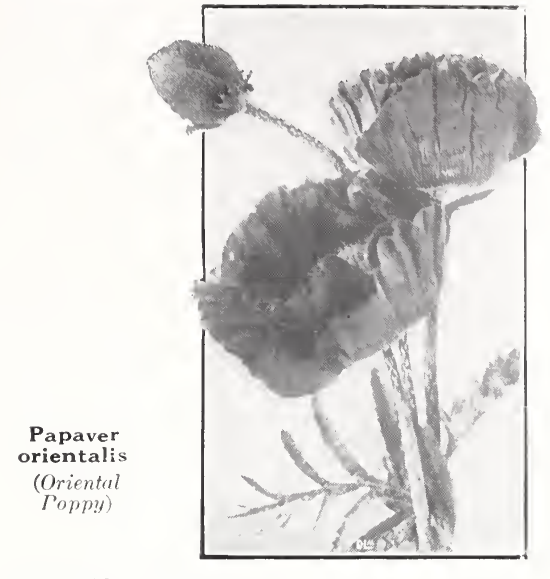

PAPAVER - Continued

Hybrid Oriental Poppies. July, 3-4 ft.

Beauty of Levermere. Bloodred. .

Goliath. Scarlet

$\$ 0.35 \$ 3.00 \$ 24.00$

Lorely. Orange-scarlet

Mrs. Perry. Salmon-pink.

Olympia. Scarlet.

Orange Queen. Orange.

Oriflamme. Orange-scarlet.

Perry White. White.

Princess Victoria Louise. Salmon-pink............

$\begin{array}{lll}.35 & 3.00 & 24.00 \\ .35 & 3.00 & 24.00 \\ .35 & 3.00 & 24.00 \\ .35 & 3.00 & 24.00 \\ .35 & 3.00 & 24.00 \\ .35 & 3.00 & 24.00 \\ .35 & 3.00 & 24.00 \\ & & \end{array}$

PENTSTEMON (Pentstemon).

heterophyllus (Violet Pentstemon). Violet, $2 \mathrm{ft}$., June and July.

laevigatus digitalis (Foxglove Pentstemon). White, $3 \mathrm{ft}$., June and July. .

torreyi (Torrey Pentstemon). Scarlet, $21 / 2-3 \mathrm{ft}$., J uly

$\begin{array}{lll}.35 & 3.00 & 24.00\end{array}$

$\begin{array}{lll}.30 & 2.40 & 15.00\end{array}$

$\begin{array}{lll}.30 & 2.40 & 18.00\end{array}$

$\begin{array}{lll}.30 & 2.40 & 15.00\end{array}$

PHALARIS (Ornamental Grass).

arundinacea variegata (Ribbon Grass). $\quad 2-3 \mathrm{ft}$.

$\begin{array}{lll}30 & 2.40 & 18.00\end{array}$

\section{PHLOX}

paniculata (Garden Phlox). These grow $2 \frac{1}{2}-3 \mathrm{ft}$., flowering from July on

Annie Cook. Flesh pink.

Atlas. Salmon pink.

B. Comte. Dark red.

Baur's Pink. Bright pink.

Blue Hill. Nearest to a blue Phlox of any varicty we have seen.

Boule de Feu. Cherry red.

Commander-in-Chief. Crimson with dark eye.

Debs. Bright fiery crimson..

Deutschland. Rich scarlet.

E. I. Farrington. Clear pink with dark eye.

Elizabeth Campbell. Bright salmon pink, dark red eye..

Enchantress. Bright salmon pink.

Eugene Damsel. Pink.

Independence. Pure white.

Jules Sandeau. Pure pink, large. $\begin{array}{lll}30 & 2.40 & 18.00\end{array}$

$\begin{array}{lll}.30 & 2.40 & 18.00\end{array}$

$\begin{array}{lll}.30 & 2.40 & 18.00\end{array}$

$\begin{array}{lll}.30 & 2.40 & 18.00\end{array}$

$35 \quad 3.00 \quad 24.00$

$\begin{array}{lll}.30 & 2.40 & 18.00\end{array}$

$.35 \quad 3.00 \quad 24.00$

$.35 \quad 2.70$

$.35 \quad 3.00 \quad 24.00$

$\begin{array}{lll}.35 & 3.00 \quad 24.00\end{array}$

$\begin{array}{lll}.35 & 3.00 & 24.00\end{array}$

$\begin{array}{lll}.30 & 2.40 & 18.00\end{array}$

$\begin{array}{lll}30 & 2.40 & 18.00\end{array}$

$\begin{array}{lll}35 & 3.00 \quad 24.00\end{array}$
$75 \quad 7.00$ 
PHLOX Continued

Lord Raleigh. Purple

Maid Marion. Soft lavender.

Mme. P. Langier. Bright red with vermilion center.

Mrs. Jenkins. Pure white.

Pantheon. Brilliant rose.

Percheau d'Island. Tall, with deep red blossoms.

R. B. Struthers. Bright pinkish salmon, crimson eye.

Special French. Glowing pink.

Tapis Blanc. Dwarf white.

Thor. Deep salmon pink.

Victor. Bright salmon pink

divaricata (Blue Phlox) (R) Lilac blue, $1 \mathrm{ft}$., May and June.

divaricata laphami. Blue flowers, $1 \mathrm{ft}$., May and June

suffruticosa (Indian Chief). Purple-red, 11/2-2 ft., June.

suffruticosa, Miss Lingard.

White, 2-3 ft., June and July.

suffrutícosa, Mrs. Verbloom. Deep pink.

subulata (Moss Pink) (R) Pink, 4 in., May and June.

subulata alba (White Moss Pink) (R) Same as above, only white

subulata, G. F. Wilson (Blue Moss Pink) (R) Lilac-blue.

subulata lilacina (R) Lilac color. subulata, The Bride (R) White, pink eye.

subulata, Virid (R) Bright fiery rose...

PHYSALIS (Groundcherry).

francheti (Lantern Groundcherry). White, 1-2 ft., July. .

PLATYCODON (Balloonflower).

grandiflorum (Balloonflower).

Deep blue, 18 in., June to Oct. grandiflorum album (White Balloonflower). White, 18 in.

June to Oct.

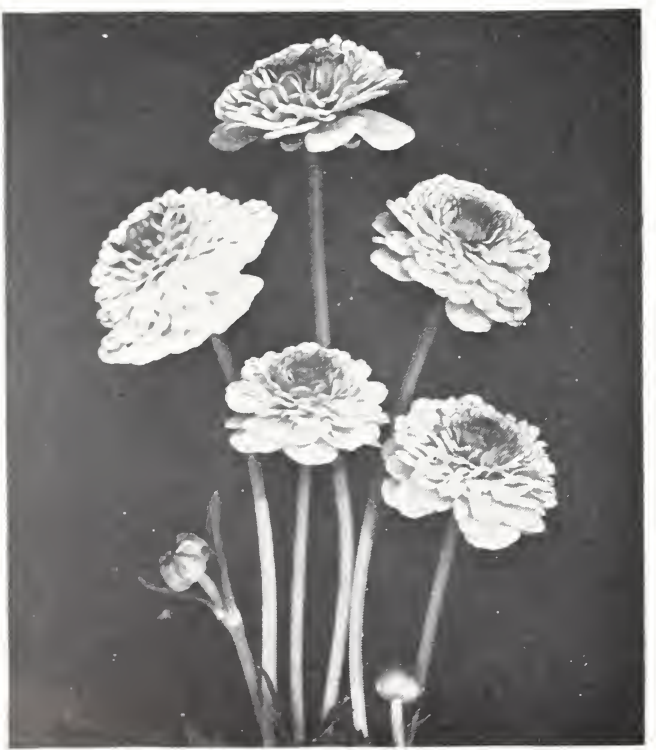

Ranunculus (Buttercup)
Each $\quad 10 \quad 100$

$\$ 0.30 \$ 2.40 \$ 1 \$ .00$

35) $3.00 \quad 2+00$

$\begin{array}{lll}30 & 2.40 & 18.00\end{array}$

$\begin{array}{lll}30 & 2.40 & 18.00\end{array}$

$\begin{array}{lll}.30 & 2.40 \quad 18.00\end{array}$

$\begin{array}{lll}.30 & 2.40 & 18.00\end{array}$

$\begin{array}{lll}30 & 2.40 & 18.00\end{array}$

$\begin{array}{lll}.30 & 2.40 & 18.00\end{array}$

.35 $\quad 2.70$

$\begin{array}{lll}30 & 2.40 & 18.00\end{array}$

$\begin{array}{lll}30 & 2.40 & 18.00\end{array}$

$40 \quad 3.00$

$\begin{array}{lll}.30 & 2.40 & 18.00\end{array}$

$\begin{array}{lll}.30 & 2.40 & 18.00\end{array}$

$.35 \quad 3.00 \quad 24.00$

$\begin{array}{lll}25 & 2.10 & 15.00\end{array}$

$\begin{array}{lll}25 & 2.10 & 15.00\end{array}$

$\begin{array}{lll}25 & 2.10 & 15.00\end{array}$

$\begin{array}{lll}25 & 2.10 & 15.00\end{array}$

$\begin{array}{lll}.30 & 2.40 & 18.00\end{array}$

$\begin{array}{lll}.50 & 4.00 \quad 36.00\end{array}$

$\begin{array}{lll}.30 & 2.40 & 18.00\end{array}$

$\begin{array}{lll}30 & 2.40 & 18.00\end{array}$

$\begin{array}{lll}.30 & 2.40 & 18.00\end{array}$
$40 \quad 3.00$
PLUMBago (See Ceratostigma)

POLEMONIUM (Polemonium).

caeruleum (Greek-valerian) ( $\mathrm{R}$ )

Blue, 11/2-2 ft., June to Sept. .\$0.30 $\$ 2.40 \$ 18.00$ caeruleum album (White Greekvalerian) ( $\mathrm{R}$ ) White, $1 \frac{1}{2}-2 \mathrm{ft}$.,

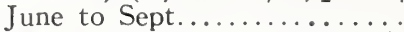

reptans (Creeping Polemonium).

(R). Blue: 8-10 in., April to

June..................... .

$\begin{array}{lll}.30 & 2.40 & 18.00\end{array}$

$.30 \quad 2.40 \quad 18.00$

POTENTILLA (Cinquefoil).

atrosanguinea (Himalayan Cinquefoil) (R) Crimson, 18 in., June to Aug. .

hybrida, Miss Willmott (R)

Cerise, 9 in., June to Aug. . . . .

PRIMULA (Primrose)

acaulis (English Primrose) (R)

Yellow, 6-8 in., May and June.

beesiana ( $R$ ) Purple, $2 \mathrm{ft}$., May and June..................

elatior (Oxlip Primrose). White,
$8-12$ in., May and June.......

japonica (Japanese Primrose). Light pink, 1-2 ft., May and July.

polyantha (Mustead Strain) (R) Yellow to orange, 6-12 in., May

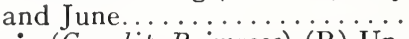
veris (Cowslip Primrose) (R) Upright form, crimson to dark yellow, 6 in., April and May....

PRUNELLA (Selfheal).

grandiflora (Great Selfheal) (R) Blue, 9-10 in., June and July. .

PYRETHRUM (Persian Daisy).

roseum (single). White, light pink, dark pink, and red, $2 \mathrm{ft}$., May and June............. roseum (single) mixed. Mixed colors, $2 \mathrm{ft}$., May and June... roseum atrosanguineum (Single Crimson). Crimson, $2 \mathrm{ft}$., May and June..............

RANUNCULUS (Buttercup).

acris fl. pl.(Tall Double Buttercup).

Yellow, $2 \mathrm{ft}$., May to Sept repens (Creeping Buttercup) (R) Yellow, 8 in., May to July....

RUDBECKIA (Coneflower).

laciniata, Goldenglow. Yellow, 5-6 ft., July to Sept. . . . . . . . triloba (Brown-eyed-susan). Deep yellow, 3-5 ft., July and Aug. .

SALVIA (Sage).

azurea grandiflora (Great Azure Sage). Light blue, 3-4 ft., Aug.

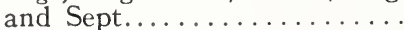
officinalis (Garden Sage). Whitish, 1-2 ft., June and July. . . . .

$\begin{array}{lll}.30 & 2.40 & 18.00\end{array}$

$\begin{array}{lll}.30 & 2.40 & 18.00\end{array}$

SANGUINARIA (Bloodroot).

canadensis (Bloodroot) (R) White 6-10 in., April and May..... .

SANTOLINA (Lavender-cotton).

chamaecyparissus (Lavender-cotton) (R) Yellow, 12 in....... $\begin{array}{lll}.30 & 2.40 & 18.00\end{array}$

$.35 \quad 2.70 \quad \ldots$.

$35 \quad 2.70$

$.35 \quad 2.70$

$.35 \quad 2.70$

$\begin{array}{lll}.30 & 2.40 & 15.00\end{array}$

$.30 \cdot 2.40 \quad 18.00$

$\begin{array}{lll}30 & 2.40 & 18.00\end{array}$

$\begin{array}{lll}.30 & 2.40 & 18.00\end{array}$

$\begin{array}{lll}.35 & 3.00 & 24.00\end{array}$

$\begin{array}{lll}.30 & 2.40 & 18.00\end{array}$

$\begin{array}{lll}.30 & 2.40 & 18.00\end{array}$

$\begin{array}{lll}30 & 2.40 & 18.00\end{array}$

$\begin{array}{lll}.30 & 2.40 & 18.00\end{array}$

$.25 \quad 2.10$

$\begin{array}{lll}.30 & 2.40 & 18.00\end{array}$
$.25 \quad 2.10 \quad \ldots \ldots$

$\begin{array}{lll}.30 & 2.40 & 18.00\end{array}$ 
SAPONARIA (Soaprort). Each $10 \quad 100$ (Rock Soapwort) (R)

Pink, 6 in., May to Aug. ....\$0.35 $\$ 2.70$

SAXIFRAGA (Saxifrage). crassifolia (Leather Saxifrage) (R) Pink, 12-15 in., April to June.

McNabiana. White, 1 ft., May and June................. $.35 \quad 2.70 \$ 20.00$ $.40 \quad 3.50$

SCABIOSA (Scabiosa).

caucasica (Caucasian Scabiosa). Lilac-blue, 18-24 in., June to

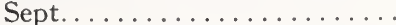

japonica (Japanese Scabiosa). Blue, $2 \mathrm{ft}$., July to Sept. . . . . . . pennsylvanicum. Creamy white, $6 \mathrm{ft}$., July and Aug. . . . . . . . .

SEDUM (Stonecrop) (R).

acre (Goldmoss) (S) Yellow, 2-4 in., May and June........... acre minor (S) Yellow, 2-3 in., June. . .

aizoon.

album (White Stonecrop) (S)

White, 4-6 in., July and Aug.

album brevifolium $(S)$.

album murale (S).

altissimum (Tall Stonecrop) (S)

White, 6-12 in., July and Aug.

altissimum nicaense $(\mathrm{S})$...

anglicum.

anglicum minor

anopetalum (S) White, $8-10$ in., July and Aug.

dasyphyllum (Leafy Stonecrop). Pinkish white, 3 in.

Edinboro (Trade Name)

ewersi (Ewers Stonecrop). Purplish pink, 4-6 in., Sept. and Oct..

griseal. White, 1 in., very compact.

hispanicum (Spanish Stonecrop) 3 in.

kamtschaticum (Orange Stonecrop). Orange-yellow, 6-9 in.,

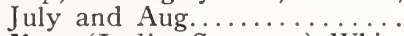

lydium (Lydian Stonecrop). White,

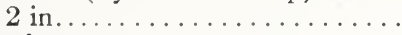
nevi.

oreganum. Yellow

populifolium (Poplar Stonecrop) Larger leaf than Spectabilis; taller and more showy...

reflexum (Jenny Stonecrop). Yellow, 8-10 in., July and Aug... sarmentosum (Stringy Stonecrop). Yellow, 6 in., May to July.

sexangulare (Hexagon Sionecrop) Yellow, 3 in.

sieboldi (Siebold Stonecrop). Pink 6 in., Aug. and Sept..........

spectabile (Showy Stonecrop)

Rosy pink, 1-11/2 ft., Aug. and September.

spectabile, Brilliant. Rosy pink, $1-11 / 2 \mathrm{ft} .$, Aug. and Sept......

spectabile variegata (Variegated Showy Stonecrop). Rosy pink, $1-11 / 2 \mathrm{ft} .$, Aug. and Sept...... spurium $(S)$.

stoloniferum (True) (Running Stonecrop) (S) Rosy pink, 4 in., July and Aug. ............ ternatum minus. $\begin{array}{lll}.35 & 3.00 & 24.00\end{array}$

$\begin{array}{lll}.25 & 2.10 & 15.00\end{array}$

$\begin{array}{lll}.25 & 2.10 & 15.00\end{array}$

$\begin{array}{lll}.25 & 2.10 \quad 15.00\end{array}$

$\begin{array}{lll}.30 & 2.40 & 18.00\end{array}$

$\begin{array}{lll}25 & 2.10 & 15.00\end{array}$

$\begin{array}{lll}25 & 2.10 & 15.00\end{array}$

$\begin{array}{lll}25 & 2.10 & 15.00\end{array}$ $\begin{array}{lll}25 & 2.10 & 15.00\end{array}$

$\begin{array}{lll}25 & 2.10 & 15.00\end{array}$ $\begin{array}{lll}.30 & 2.40 & 18.00\end{array}$
SEMPERVIVUM (Houseleek). arachnoideum (Spiderweb Houseleek (R) Bright red, 4 in .

$\$ 0.25 \$ 2.10 \$ 15.00$

lobiferum (Globe Houseleek) (R) Yellow, 6-9 in

hirtum (cornutum) (Italian Houseleek) (R). .

potsi $(R)$ Yellow, 6 in . . . . . . . soboliferum (Hen-and-chickens) (R) Yellow, 6-9 in .

tectorum (Roof Houseleek) (R) Red, 8-12 in.

tectorum violaceum ( $V$ io let Houseleek) (R) Violet, $1 \mathrm{ft}$. .

$\begin{array}{lll}25 & 2.10 & 15.00\end{array}$

$\begin{array}{lll}.25 & 2.10 & 15.00\end{array}$

$\begin{array}{lll}.25 & 2.10 & 15.00\end{array}$

$\begin{array}{lll}.25 & 2.10 & 15.00\end{array}$

$.25 \quad 2.10 \quad 15.00$

$\begin{array}{lll}.25 & 2.10 & 15.00\end{array}$

$\begin{array}{lll}.25 & 2.10 & 15.00\end{array}$

SIDALCEA (Prairiemallow)

Rosy Gem. Rose pink, $3 \mathrm{ft}$. June.

SILENE (Catchfly).

aplestris (Alpine Catchfly) (R) White, 4 in., May and June. .

schafta (Schafta Catchfly) (R) Rose pink, 4-6 in., June to Sept.

STATICE (Thrift).

armeria (A rmeria maritima) (Common Thrift) (R) Purplish rose, 3-6 in., May and June. .

pseudoarmeria (Armeria formosa) (False Thrift) (R) White, 8 in., May and June.

pseudoarmeria rubra ( $R$ ) Rose, 8 in., May to June.

Rosalie (Armeria laucheana) (R) Rose, 8-10 in., June to Oct. . . .

TEUCRIUM (Germander).

orientale (R) Blue, 8 in

THALICTRUM (Meadowrue). aquilegifolium (Columbine $\mathrm{Mea}$ dowrue). Cream, 2-3 ft., May to July. .

THERMOPSIS (Thermopsis). mollis (Soft Thermopsis). Yellow, 2-3 ft., May to Aug

$\begin{array}{lll}30 & 2.40 \quad 18.00\end{array}$

$\begin{array}{lll}35 & 3.00 \quad 24.00\end{array}$

$\begin{array}{lll}.30 & 2.40 & 18.00\end{array}$

$\begin{array}{lll}.25 & 2.20 & 15.00\end{array}$

$\begin{array}{lll}.25 & 2.20 & 15.00\end{array}$

$\begin{array}{lll}.25 & 2.20 & 15.00\end{array}$

$\begin{array}{lll}.30 & 2.40 & 18.00\end{array}$

$\begin{array}{lll}.50 & 4.00 \quad 36.00\end{array}$

$\begin{array}{lll}30 & 2.40 & 18.00\end{array}$

$40 \quad 3.00$

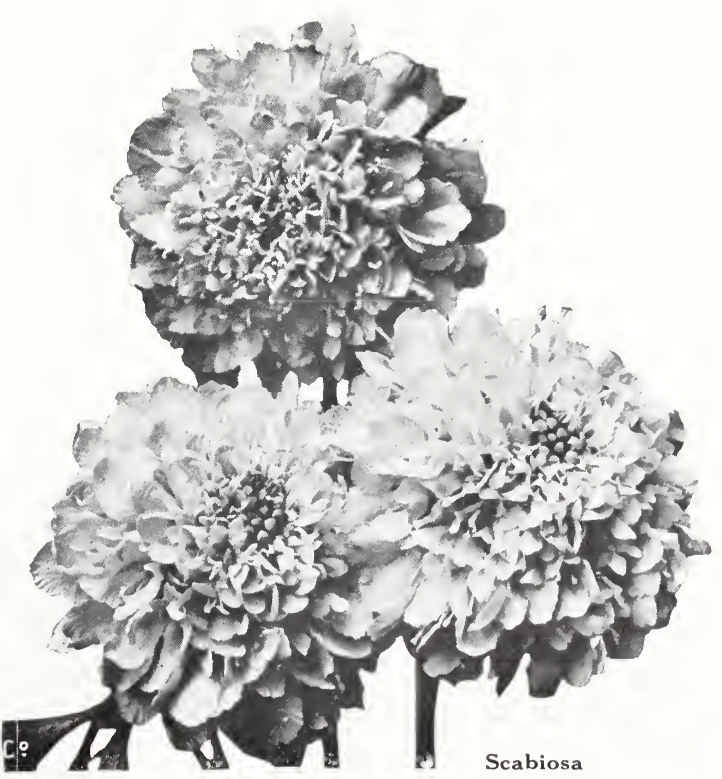


THYMUS (Thyme)

serpyllum (Mother-of-thyme) ( $R$

Lilac, 6 in., July and Aug.

serpyllum aureum (R)

serpyllum citriodorus (Lemon-

scented Thyme) (R) Pink, $t$ in.

July and Aug

serpyllum lanuginosus (IToolly Thyme) (R) Reddish pink, 4 in. Aug

TRADESCANTIA (Spiderwort).

virginiana ('irginia Spiderwort)

Blue, 2 ft., July and Aug.

TROLLIS (Globeflower)

asiaticus (Siberian Globeflower). Orange, $1-11^{1}$ ft., May and June europaeus (Common Globeflower). Lemon-yellow, 1-11/2 ft., May and August.

Dwyer's Giant. Yellow, $2-2 !_{2} \mathrm{ft}$. May to July.

TUNICA (Tunicflower).

saxifraga (Saxifrage Tunicflower) (R) Pink, 6 in., all Summer. saxifraga alba (White Saxifrage Tunicflower (R) IVhite, 6 in., All Summer..

VALERIANA (Talerian),

Offlinalis (Garden Heliotrope). Lavender, $4 \mathrm{ft}$., June.

VERBASCUM (Hullein)

densiflorum. Yellow, $4-6 \mathrm{ft}$., June and July......

VERONICA (Speedwell).

allioni (Allioni Speedwell) (R) Violet, 6-1s in., Nay to July. longifolia subsessilis (Clump Speedwell). Blue, $2 \mathrm{ft}$., July to Sept

longifolia subsessilis, Blue Jay. Violet-blue, 3-4 ft., July to Sept. repens (Creeping Speedwell) (R) Light blue, 3-4 in., May and June. . .

spicata (Spike Speedwell). Violetblue, 18 in., June and July....
Each $\quad 10 \quad 100$

$\$ 0.30 \$ 2.40 \$ 18.00$

$35 \quad 3.00 \quad 24.00$

$30 \quad 2.40 \quad 15.00$

$30 \quad 2.40 \quad 15.00$

$\begin{array}{lll}30 & 2.40 & 18.00\end{array}$

$.50 \quad+.00 \quad 36.00$

$40 \quad 3.50$

$.50 \quad 4.00 \quad 36.00$

$\begin{array}{lll}.30 & 2.40 & 18.00\end{array}$

$\begin{array}{lll}.30 & 2.40 & 18.00\end{array}$

$\begin{array}{lll}.30 & 2.40 \quad 18.00\end{array}$

$\begin{array}{lll}.30 & 2.40 & 18.00\end{array}$

$.35 \quad 3.00 \quad 24.00$

$40 \quad 3.50 \quad 30.00$

$.40 \quad 3.50$

$35 \quad 2.70$

$\begin{array}{lll}.30 & 2.40 & 18.00\end{array}$

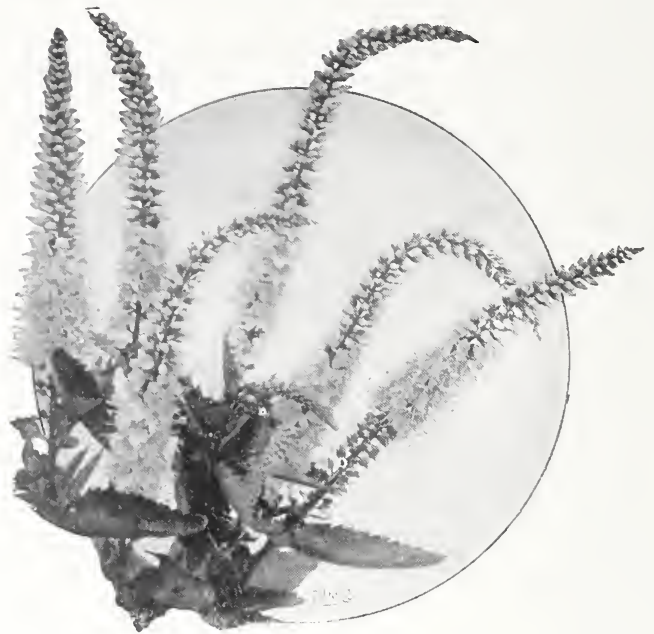

Veronica (Speedwell)

VINCA (Periwinkle).

Each $\quad 10 \quad 100$

minor (Common Periwinkle) (S) Bright blue; ground cover;

Spring, Summer and Autumn.

Pot grown............... \$0.25 \$2.10\$15.00

Field grown............... $\quad .25 \quad 2.10 \quad 15.00$

minor alba (White Common Periwinkle). Same as above, only

white.................. $40 \quad 3.50 \quad 31.50$

VIOLA (Violet).

cornuta (Tufted Pansy) (R) Light blue, 8 in., April to Oct......

cucullata (Blue Marsh Violet).

Dark blue, 8 in., April and May. $\quad .25 \quad 2.20 \quad 15.00$

Jersey Gem (R) Violet-blue, 8 in., April to Oct............

Hybrids (Tufted Pansies) (R) 6 in., June to Sept

Admiration. Dark blue..... . $\quad .25 \quad 2.10 \quad 15.00$ Lutea. Yellow . . . . . . . . . . .25 $2.10 \quad 15.00$

$\begin{array}{llll}\text { Mauve Queen. Reddish violet. } & .25 & 2.10 & 15.00\end{array}$

Purple Queen. Purple...... .25 $2.10 \quad 15.00$

White Perfection. White.... $\quad .25 \quad 2.10 \quad 15.00$

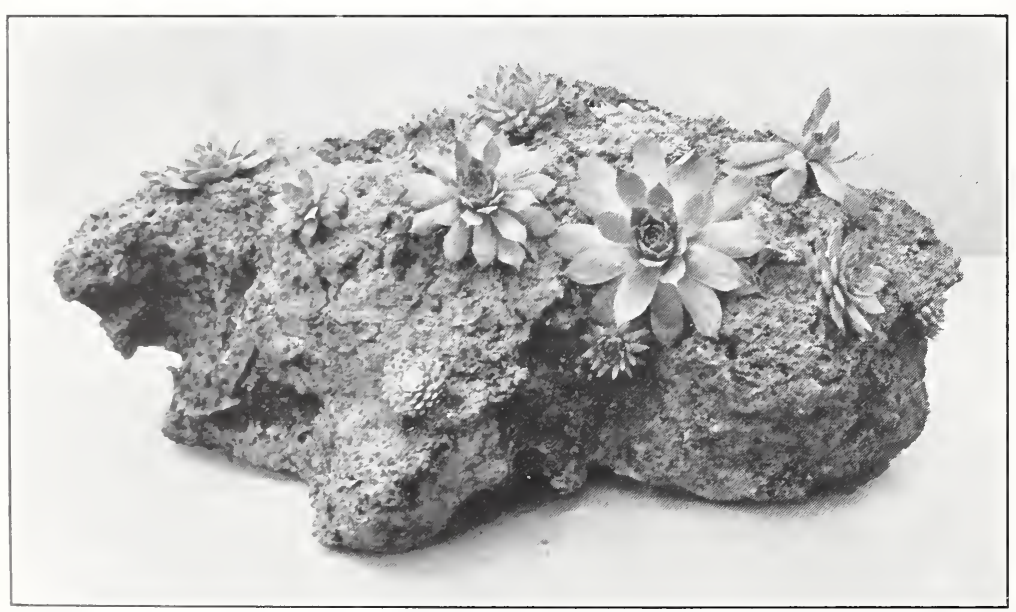

Sempervivum (Houseleek). See page 37
YUCCA $($ Yucca).

filamentosa (Common Yucca). Creamy white, 4-5 ft., June and July.
4 yrs. . . $\$ 0.40 \$ 3.50$

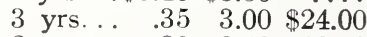

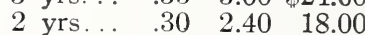

\section{PERENNIAL SPECIAL OFFER}

Any 5, lots of 3 each 25c. Perennials-15 plants for.......\$2.95

Any 5, lots of 3 each30c. Perennials-15 plants for........ 3.45

Any 5, lots of 3 each 35c. Perennials-15 plants for . . . . . . 3.95 


\section{Climbing and Trailing Plants}

ACTINIDIA arguta. Bower Actinidia. $25 \mathrm{ft}$. A sturdy Japanese vine with large leaves and white purple centered flowers.

3 yrs.
2 yrs.

Each

$\$ 1.00$

$8 S^{-10}$

.85

7.50

AMPELOPSIS quinquefolia. Virginia Creeper. 50 ft. (S) A prolific grower to any height. Splendid for covering walls, fences and old stumps. Deep

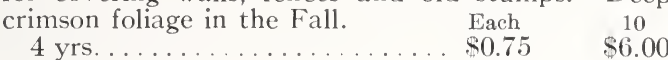

A. tricuspidata. Japanese Creeper or Boston Ivy. 60 $\mathrm{ft}$. Even more vigorous than the above. Immune to insects, disease and smoke.

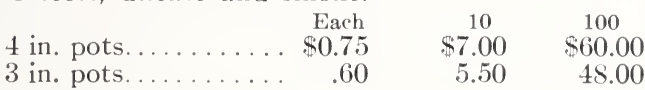

ARISTOLOCHIA sipho. Dutchmans-pipe. $25 \mathrm{ft}$. A fine screen, large leaves with brownish pipe-shaped flowers in the Spring. $\quad$ Each 10
4 yrs
$\$ 1.50$
$\$ 13.50$

BIGNONIA radicans. Trumpetcreeper. $30 \mathrm{ft}$. Tall growing, twining vine bearing orange flowers in

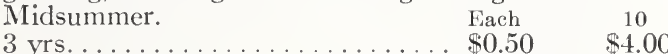

CELASTRUS orbiculatus. Oriental Bittersweet. 15 $\mathrm{ft}$. Round leaves, vigorous climber with orange berries bursting in the Autumn disclosing flame-colored centers. Each $\quad 10 \quad 100$

4 yrs......... $\$ 0.90 \quad \$ 7.50 \quad \$ 60.00$

C. scandens. American Bittersweet. $15 \mathrm{ft}$. A charming rambler with lovely, shiny, roundish leaves and bright orange berries on display all Winter.

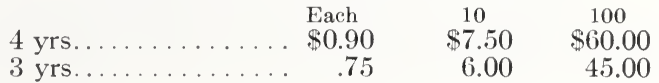

CLEMATIS paniculata. Sweet Autumn Clematis. $20 \mathrm{ft}$. (S) Delicate white blossoms like a bit of old lace; this graceful vine climbs over trellis and porches.

\begin{tabular}{|c|c|c|c|}
\hline & $\begin{array}{l}\text { Each } \\
\$ 075\end{array}$ & $\begin{array}{l}10 \\
\$ 6\end{array}$ & $\begin{array}{c}100 \\
\$ 4800\end{array}$ \\
\hline$y$ & .60 & 5.00 & 39.00 \\
\hline
\end{tabular}

HEDERA helix. English $I v y .60 \mathrm{ft}$. The always satisfactory climber for brick or stone walls; dark, glossy, white veined leaves. Each $10 \quad 100$ 3 in. pots.........\$0.60 \$5.50 \$48.00

H. helix baltica. Hardy English Ivy. A very hardy variety similar to English Ivy, but with leaves a little smaller, darker and richer. Each 10 3 in. pots..............\$0.75 \$6.50

LONICERA japonica aureoreticulata. Yellownet Japanese Honeysuckle. $26 \mathrm{ft}$. Leaves of variegated gold and green, slow growth, but sturdy and handsome.

Each

10

$\$ 0.50$

$\$ 4.00$

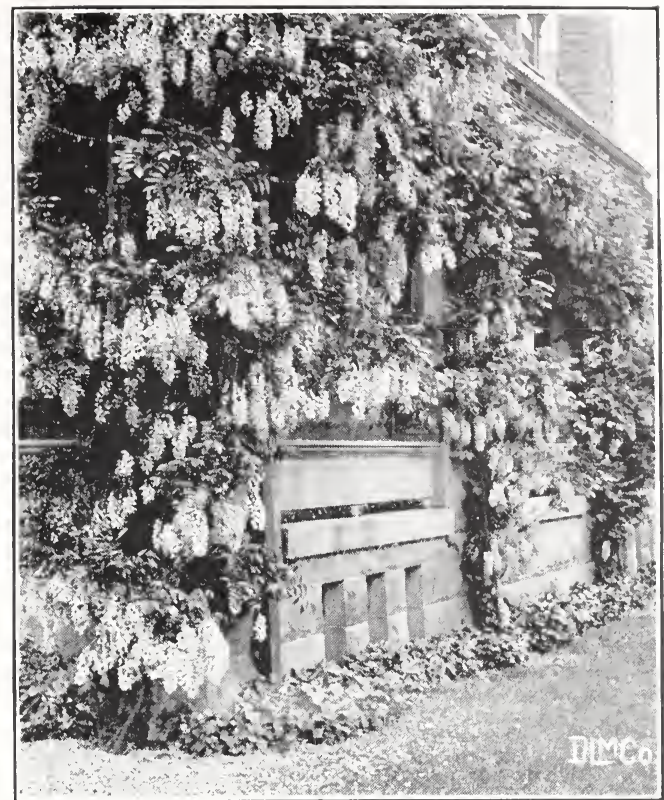

Wisteria sinensis (Chinese Wisteria)

LONICERA - Continued

L. japonica halliana. Hall Japanese Honeysuckle. $26 \mathrm{ft}$. Deliciously fragrant blossoms of white, turning to buff; dark glossy-green foliage.

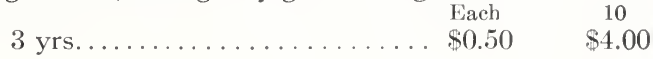

L. sempervirens. Trumpet Honeysuckle. $26 \mathrm{ft}$. Glorious blossoms in scarlet from May until September. A choice possession.

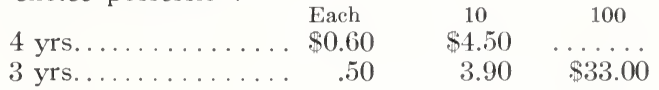

LYCIUM chinense. Chinese Matrimony-vine. $10 \mathrm{ft}$. Charming against low walls and over rocks. A profusion of vivid purple, star-shaped flowers, changing to scarlet berries an inch in length. These, against rich green foliage, are most effective.

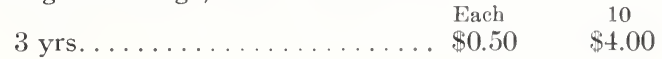

WISTERIA sinensis. Chinese Wisteria. $25 \mathrm{ft}$. One of nature's most graceful showers of loveliness. This variety has light green foliage and violet-blue flowers of pea-shape in drooping clusters.

\begin{tabular}{lrrr}
6 yrs. $\ldots \ldots \ldots \ldots \ldots \ldots$ & $\$ 2.00$ & \multicolumn{1}{c}{$\begin{array}{c}10 \\
\$ 18.00\end{array}$} & \multicolumn{1}{c}{100} \\
5 yrs $\ldots \ldots \ldots \ldots \ldots$ & 1.25 & 10.00 & $\$ 90.00$ \\
4 yrs $\ldots \ldots \ldots \ldots \ldots \ldots$ & 1.00 & 8.00 & 69.00 \\
3 yrs $\ldots \ldots \ldots \ldots \ldots \ldots$ & .75 & 6.00 & $\ldots \ldots \ldots$
\end{tabular}

W. sinensis alba. White Chinese Wisteria. $25 \mathrm{ft}$. Same as above, except flowers are white.

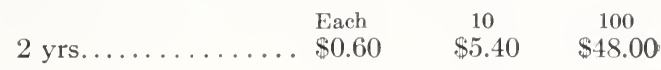




\title{
Roses
}

\section{Suggestions for the Culture of Roses \\ "A sweeter flower did nature ne'er put fortb" \\ -William Browne}

\begin{abstract}
A SUCCESSFUL Rose Garden is the goal of every grower of flowers. They thrive best in a garden where the morning sun reaches them. Excavate to a depth of 2 feet, place a layer of cow manure on the bottom and fill with good top soil, building the bed to a height of 4 inches above the ground level.

Space Hybrid Tea Roses 18 inches, and Hybrid Perpetuals 2 feet apart, thus allowing plenty of room for the roots to spread out. All Roses should be planted so the place where they are grafted or budded is 3 inches below the surface. Tramp in firmly and water well. Keep the ground well mulched. To secure the most perfect blossoms, cut each flower when the bud is opening.

Cut the plants back in the Fall after two or three frosts and cover them during the Winter months. Roses should be uncovered in the early Spring and pruned again severely. The addition of manure and cultivation at this time will help you obtain perfect flowers.
\end{abstract}

Strong, fleld grown plants, 2 years old: 75c. each,

5 or more of one kind at 65c. each, unless otherwise noted

If we are out of the variety ordered, we shall select the variety most closely resembling it unless otherwise advised.

\section{Hybrid Perpetual Roses RED}

General Jacqueminot. Bright scarlet crimson.

Hugh Dickson. Brilliant crimson, shaded with scarlet. M. P. Wilder. Cherry carmine.

Ulrich Brunner. Brilliant cherry-red.

\section{PINK}

Anne de Diesbach. Large double carmine.

Clio. Large flesh color; rosy-pink center.

Mme. Gabriel Luizet. Light silvery pink.

Magna Charta. Pink and carmine.

Mrs. John Laing. Large soft pink; fragrant and steady bloomer.

Paul Neyron. Deep rose; very large.

\section{WHITE}

Frau Karl Druschki (Snow Oueen). Pure white.

Mme. Plantier. Pure white.

Margaret Dickson. White, with pale flesh center; large.

\section{YELLOW}

Harison's Yellow. Bright yellow, semi-double.

Persian Yellow. Deep yellow.

\section{Hybrid Tea Roses RED}

Betty Uprichard. Copper-red buds, semi-double orange-carmine flowers.

Etolle de France. Large, double, velvety crimson; center ruby red.

Gruss an Teplitz. Scarlet, shading to velvety crimson.

Red Radiance. Similar to Radiance, only deep red.

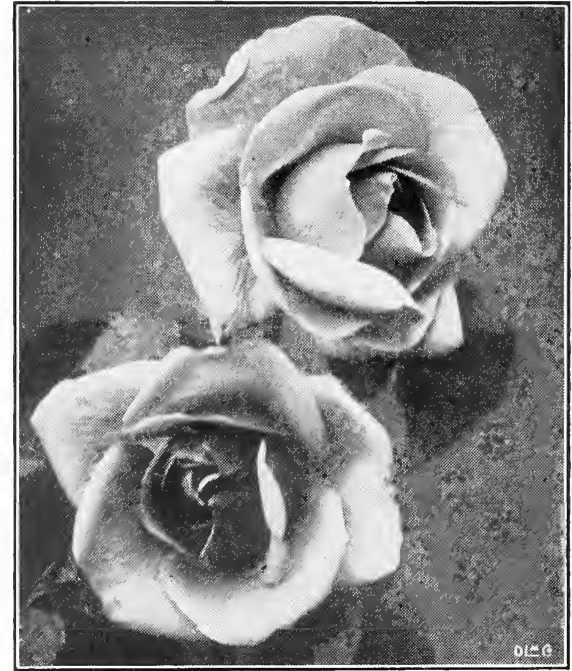

Rose, Betty Uprichard

\section{PINK}

Briarcliff. Handsome flowers of silvery rose-pink.

Columbia. Beautiful rose pink blossoms.

Commonwealth. Deep pink.

Dame Edith Helen. New variety; large blossoms of pure pink.

Jonkheer J. L. Mock. Deep carmine pink.

Killarney Queen. Long, pointed buds of deep shell pink.

Lady Alice Stanley. Outside petals coral pink, inside pale flesh pink.

Mme. Butterfly. Large, brilliant pink flowers suffused with apricot and gold.

Mme. Caroline Testout. Salmon pink; large.

Ophelia. Salmon flesh, shaded with rose.

Radiance. Brilliant carmine-pink with salmon-pink and yellow shadings. 
HYBRID TEA ROSES Continued

Strong, field grown plants, 2 years old: $75 \mathrm{c}$. each, 5 or more of one kind at 65c. each, unless otherwise noted

\section{WHITE}

Kaiserin Auguste Viktoria. Soft creamy white. Killarney White. Pure white; long pointed buds. William R. Smith. Creamy white, suffused with rosepink.

\section{YELLOW}

Golden Ophelia. Beautiful yellow form of the lovely Ophelia.

Independence Day. Flaming yellow buds, shaded copper.

Luxembourg. Rich coppery yellow.

Mrs. Aaron Ward. Coppery orange in open bud, pinkish fawn when full.

Mrs. Calvin Coolidge. Buff yellow, orange center.

President Hoover. A blend of orange and pink, varying in tone from coppery red in the bud to glowing orange-yellow at the base of the petals, suffused with vivid rose-pink, $\$ 1.50$ each.

Rev. F. Page-Roberts. Golden yellow blooms, stained with copper on outer petals.

Souvenir de Claudius Pernet. New Rose of beautiful Sunflower vellow, brilliant green foliage, and few thorns.

Talisman. Sensational new brilliantly colored rose of bright yellow, gold and pink. \$1.25 each; 5 or more at $\$ 1.00$ each.

\section{POL YANTHA ROSES}

Ellen Poulsen. Bright rose pink.

Ideal. Velvety dark red.

Miss Edith Cavell. Scarlet red.

\section{Climbing Roses}

Strong, field grown plants: 60c. each; 5 or more of one kind at $50 \mathrm{c}$. each, unless otherwise noted

\section{RED}

Climbing American Beauty. Large crimson flowers.

Crimson Rambler. Immense clusters of clouble crimson flowers.

Excelsa. Double crimson flowers; good foliage.

Hiawatha. Single, deep crimson, clear white at base of petals.

Paul's Scarlet Climber. Vivid scarlet.

\section{PINK}

American Pillar. Single rosy pink.

Dr. Van Fleet. Deep flesh pink.

Dorothy Perkins. Shell pink.

Mary Wallace. Semi-double, bright, clear rose pink. $\$ 1.00$ each; 5 or more at 90 c. each.

Mme. Gregoire Staechelin. Remarkable new climbing Rose, producing an abundance of glorious carmine pink blooms. Fragrant. $\$ 1.50$ each.

Tausendschon. Large trusses of pink flowers.

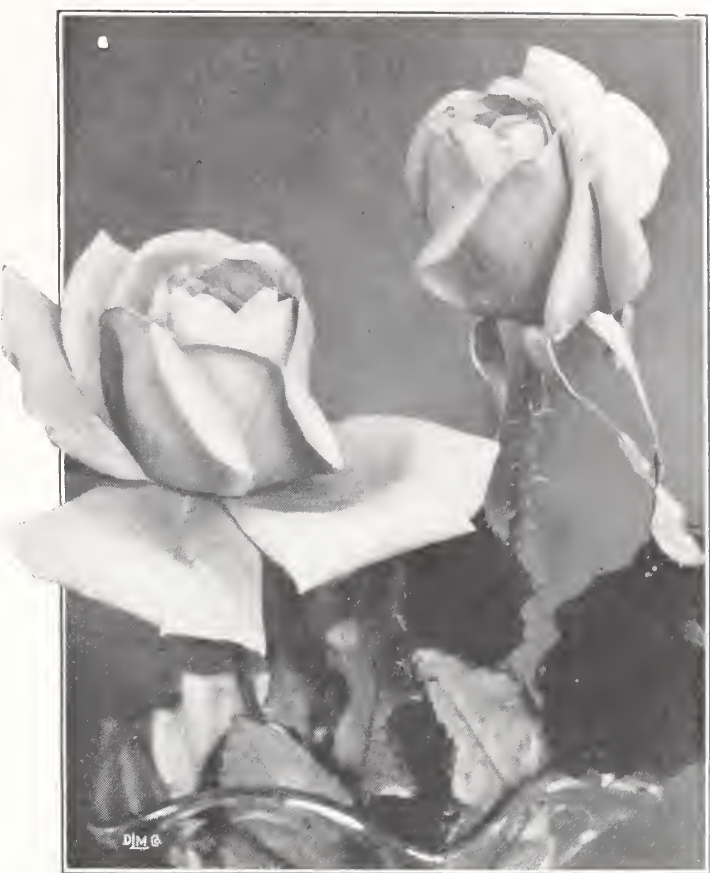

Rose, Souvenir de Claudius Pernet

\section{WHITE}

Silver Moon. Semi-double, pure white flowers.

White Dorothy Perkins. Double pure white Howers.

\section{YELLOW}

Gardenia. Buds bright yellow, flowers cream. Very hardy.

\section{Rosa Rugosa Hybrids}

$\$ 1.00$ each; 5 or more of one kind at $90 \mathrm{c}$. each Hansa. Reddish violet; double.

Sarah Van Fleet. New variety of medium rose pink. Sir Thomas Lipton. Double white.

\section{ROSE SPECIAL OFFER}

Any four 75c. Hybrid Tea or Hybrid Perpetual Roses-plus 1 Talisman for $\$ 3.70$

Any four 75c. Hybrid Tea or Hybrid Perpetual Roses-plus 1 President Hoover for. 


\section{Fruit Trees}

Two years, $5.7 \mathrm{ft}$.

\section{STANDARD APPLES}

$\$ 1.00$ each: 5 or more of one kind at 90c. each.

\section{SUMMER VARIETIES}

Fameuse

Red Astrachan

Yellow Transparent

$\begin{array}{ll}\text { AUTUMN VARIETIES } \\ \begin{array}{l}\text { Early Harrest } \\ \text { Fall Pippin } \\ \text { Gravenstein }\end{array} & \begin{array}{l}\text { Oldenburg } \\ \text { Wealthy }\end{array} \\ \text { WINTER VARIETIES } \\ \text { Baldwin } & \text { Rhode Island Greening } \\ \text { Bellflower } & \text { Roxbury Russet } \\ \text { Delicious } & \text { Stark } \\ \text { MeIntosh Red } & \text { Stayman Winesap } \\ \text { Northern Spy } & \text { Tolman Sweet }\end{array}$

\section{DWARF APPLES}

Two years.

$\$ 1.25 \mathrm{each} ; 5$ or more of one kind at $\$ 1.10$ each $\begin{array}{ll}\text { Baldwin } & \text { Northern Spy } \\ \text { Gravenstein } & \text { Oldenburg }\end{array}$

King

CRAB APPLES

Two rears, $5-7 \mathrm{ft}$.

$\$ 1.00$ each; 5 or more of one kind at $90 \mathrm{c}$. each Hyslop

Transcendent

\section{STANDARD PEARS}

Two years, $5-7 \mathrm{ft}$.

$\$ 1.50$ each; 5 or more of one kind at $\$ 1.25$ each

$\begin{array}{lc}\text { Bartlett } & \text { SUMMER VARIETIES } \\ & \text { Clapp's Favorite } \\ \begin{array}{l}\text { Beurre Bose } \\ \text { Sheldon }\end{array} & \text { AUTUMN VARIETIES } \\ & \text { Seckel }\end{array}$

\section{CHERRIES}

Two years; $5-7 \mathrm{ft}$.

$\$ 1.50$ each; 5 or more of one kind at $\$ 1.40$ each SWEET

Black Tartarian Napoleon Bigarreau

Governor Wood

TART

Early Richmond

Montmorency

\section{PEACHES}

$4-5 \mathrm{ft}$.

75c. each; 5 or more of one kind at 60c. each
Crawford's Early
Crawford's Late
Rochester
Elberta
Stump

\section{PLUMS}

Two years, $5-7 \mathrm{ft}$.

$\$ 1.50$ each, 5 or more of one kind at $\$ 1.40$ each

$\begin{array}{lc}\text { Abundance } & \text { JAPANESE } \\ \text { Burbank } & \text { Damson } \\ & \text { Red June } \\ \text { Bradshaw } & \text { EUROPEAN } \\ \text { Green Gage } & \text { Lombard } \\ & \text { Shropshire Damson }\end{array}$

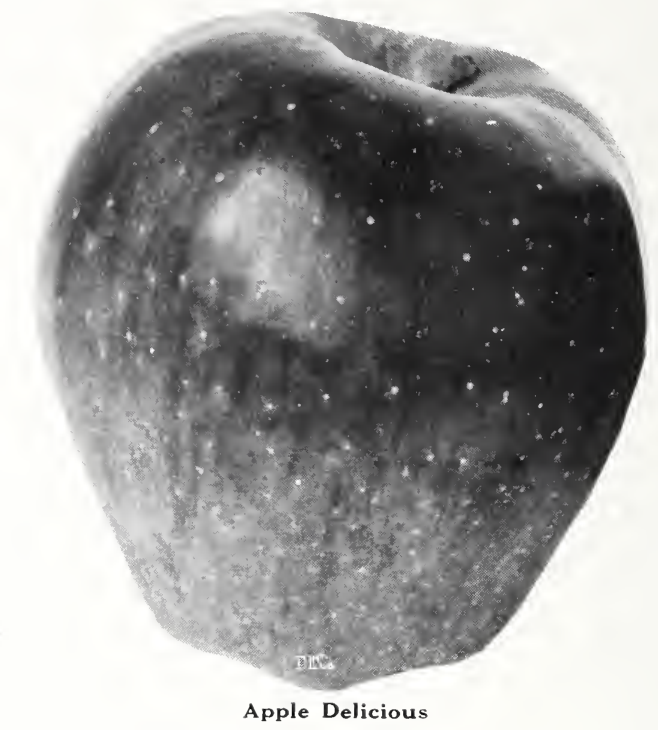

4-5 ft.

QUINCES

$\$ 1.25$ each; 5 or more of one kind at $\$ 1.10$ each

Champion

Orange

\section{Small Fruits}

\section{ASPARAGUS}

Two year roots.

$\$ 1.00$ per 25, $\$ 3.00$ per 100

Conover's Colossal

Martha Washington

Palmetto

\section{BLACKBERRIES}

Erie

$$
\$ 1.25 \text { per } 10, \$ 10.00 \text { per } 100
$$

Eldora

Snyder

Two years.

\section{GRAPES}

60c. each; 5 or more of one kind at 50c. each, unless otherwise noted

\section{BLUE-BLACK}

Campbell's Early

Concord

Worden

$$
\begin{aligned}
& \text { Agawam } \\
& \text { Brighton }
\end{aligned}
$$
RED

Delaware

Salem

\section{WHITE}

Green Mountain. $75 \mathrm{c}$. each; 5 or more at $65 \mathrm{c}$. each. Moore's Diamond

\section{Niagara}

\section{RASPBERRIES}

$\$ 1.25$ per $10 ; \$ 10.00$ per 100

$\begin{array}{ll}\text { Columbian } & \text { Herbert } \\ \text { Cuthbert } & \text { St. Regis } \\ \text { Golden Queen } & \end{array}$

\section{RHUBARB}

Linnaeus. 30 c. each; 5 or more at 25 c. each. 


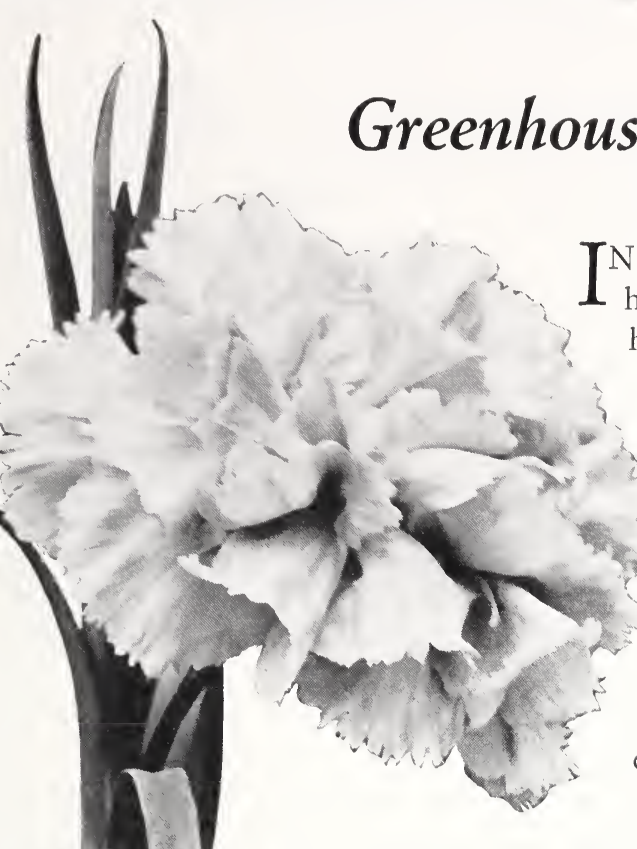

TN this catalog we would like to emphasize our Greenhouses. Many of our customers do not know that we have over 15,000 square feet under glass. Our specialty is Carnations. At the present time we have propagated three new varieties which are attracting nation-wide interest among Carnation growers. These have already won many prizes and awards of merit.

In addition to Carnations, we have in their season Chrysanthemums, Freesias, Stevia, Snapdragon, the new beautiful Blue Iris, Calla Lilies, Calendulas, Roses, Calla Lily Begonias, Echeverias, and a general line of Potted Plants.

Every Spring we have thousands of Annuals in many colors and varieties. Our collection this Spring will Scarlet be one of the finest in this section of the country. We list below Monarch some of the varieties we will have.

The Greenhouse, also, has a fast enlarging Cut Flower Department, completely equipped to meet our patrons' needs for Bridal Arrangements, Decorations for Home or Church, and all other floral tributes and gifts, such as Sprays, Baskets, Wreaths, Bouquets, etc.

Prices on the following depends on size and variety. Write for quotations.

Ageratum, Blue Perfection. Large flowered mauve; free blooming.

ALYSSUM compactum, Little Gem. White, free flowering; fine for bedding or rockeries.

ASPIDISTRA lurida variegata. Striped leaf; house plant.

ASTER, Queen of the Market. Very early blooming. Blush, Bright Rose, Crimson, Dark Blue, White

BEGONIA, Calla Lily. Pink blossoms; leaf similar to Calla Lilv.

semperflorens. Pink blossom.

\section{CACTUS.}

CALENDUlas, Lemon Queen, Orange King.

\section{CANNAS, Green Foliage:}

Beaute Poitevine. Deep crimson; $31 / 2 \mathrm{ft}$.

Eureka. White; $4 \mathrm{ft}$.

Express. Deep crimson; $3 \frac{1}{2} \mathrm{ft}$.

Mme. Berat. Rose pink; $4 \mathrm{ft}$.

Mme. Crozy. Vermilion scarlet with narrow golden border; $3 \frac{1}{2} \mathrm{ft}$.

Mrs. Alfred Conard. Salmon pink; $3 \frac{1}{2} \mathrm{ft}$.

Pennsylvania. Scarlet, overlaid with orange; $6 \mathrm{ft}$.

President. Crimson; $4 \mathrm{ft}$.

Richard Wallace. Canary_yellow; $4 \mathrm{ft}$.

Bronze Foliage:

King Humbert. Orange scarlet; $4 \mathrm{ft}$.
CARNATION, Scarlet Monarch. A new bright red introduction of ours. This is a wonderful flower that is very popular, and is the outstanding red Carnation on the market. The flower is very large, and is supported by a very strong and long stem. It has been awarded honors this year at every flower show where it was possible to have it displayed.

Boston Ward. Bright pink.

Salmon Spectrum. Salmon pink.

Orchid Beauty. A new orchid lavender seedling of ours. A very unusual and beautiful flower.

Ivory. Pure white.

Golden Wonder. This variegated yellow Carnation is another one of our introductions. It has won many prizes and awards of merit. Unquestionably, it is the finest variegated yellow Carnation that has ever been introduced.

CELOSIA plumosa. Mixed colors.

CENTAUREA imperialis. Dark purple; giant flowers.

ClARKIA, Orange King. Good for cutting.

COLEUS.

COSMOS (Cosmea), Express. Very early; fine for cutting.

Crimson

Rose

White

CRASSULA arborescens (Japanese Rubber Plant). Good house plant.

DRACAENA indivisa (Ribbon Palm). 


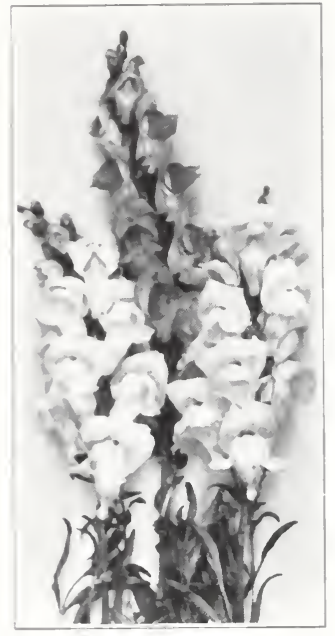

Snapdragons

ECHEVERIA.

FICUS elastica (Rubber Plant).

GERANIUMS.

Alphonse Ricard. Semi-double, bright vermilion scarlet.

Beaute Poitevine. Double salmon pink.

Michael Buchner. White.

Radio Red. Scarlet.

Salmon Ideal. Semi-double, salmon.

S. A. Nutt. Crimson, semi-double.

IV YLEAVED GERANIUMS, Pink. From pots, Hanging baskets.

HELIOTROPE.

HYDRANGEAS, French.

LANTANA, Dwarf Hybrids. Orange and scarlet.

LOBELIA, Cambridge Blue. Pale blue, large flowered and compact. Splendid for bedding and edging plant.

Basket. Rich purplish blue with white eye. Particularly adapted for hanging baskets.

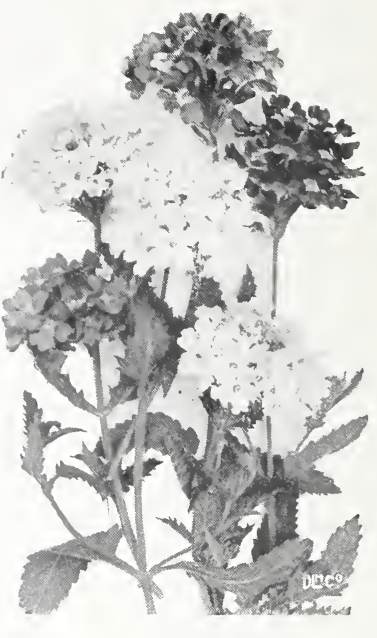

Verbena
LUPINUS, Annual Varieties. Dwarf; mixed colors.

MARIGOLDS, African Lemon. Pure lemon color;

large.

French: Gold Striped. Dwarf.

Dark Yellow. Dwarf.

Double Golden. Pigmy, suitable for beds and edging.

MYRTUS communis (Myrtle).

PETUNIAS, Bedding Varieties:

Alderman. Dark violet.

Erfordia. Bright rose.

Rosy Morn. Bright rosy pink with white throat.

Violet Queen. Deep violet.

PELARGONIUMS Martha Washington Geraniums).

Pink with Crimson Blotch.

White with Crimson Blotch.

Springtime.

PHLOX drummondi nana compacta.

Apricot Chamois Rose Fireball Purple

SALVIA patens, "Cambridge Blue." New variety; bright blue; valuable for bedding.

splendens. Tall; scarlet spikes.

splendens, "Fireball.", Dwarf, brilliant scarlet, Summer flowering.

splendens, "Scarlet Queen." Vivid scarlet spikes.
SALPIGLOSSIS grandiflora. Large flowered; mixed colors.

SCHIZanthus, Pink Beauty. Exquisite rose pink.

SNAPDRAGON, Orange Beauty. New variety; orange scarlet with gold lip.

roseum. Deep rosy pink.

Ruby. Rich ruby pink.

THUNBERGIA (Black-eyed Clockvine). Mixed colors.

TORENIA bailloni. Yellow, with purple throat.

Fournier grandiflora. Large violet blue and pale mauve flowers.

URSIANA anethoides. Orange, daisylike flowers with purple zone around center.

Mixed. Daisylike flowers, varying from sulphur yellow to rich orange.

VERBENA hybrida. Splendid bedding plants.

Dark Blue

Pure White

Scarlet

Lemon Scented. Lemon color, sweet scented.

VINCA (Periwinkle).

WANDERING-JEW.

ZINNIA elegans. Double.

$\begin{array}{crcc}\text { Dark Scarlet } & \begin{array}{r}\text { Flesh } \\ \text { Rose }\end{array} & \begin{array}{c}\text { Golden } \\ \text { Scarlet }\end{array} & \text { Yellow }\end{array}$

Red Riding Hood. Scarlet, excellent for borders or bedding.

Prices on the above depend on size and variety. Write for quotations.

\section{Bulb Department}

We have the following bulbs to offer in season:

Crocus

Gladiolus

Hyacinths

NARCISSUS

TuLIPS

\section{Garden Furniture}

We can furnish our clients with a complete line of Garden Furniture and Fixtures at economical prices. 


\section{Native Section \\ "Give me a native Hemlock, Pine and Spruce \\ Or Columbine, Aster and Fern- \\ The Azalea, Snowberry and Paper Birch \\ From whom I, of Nature, may learn."-Anonymous.}

$\mathrm{M}$ ANY times we have been asked: "Do you have Native Plant Material?" Our-answer is, emphatically-Yes! For your quick reference and convenience, we list below the more important Native Plants carried in our Nurseries. These are all nursery grown. This means each plant has been several times transplanted, insuring a fine fibrous root system-your] assurance that the plant will live and grow when transplanted to your garden.

We will gladly send information and quotations on any other Native Plants not mentioned in this list which you may be interested in.

Abies concolor

Juniperus communis aurea

Juniperus horizontalis

Juniperus virginiana

Juniperus virginiana glauca

Picea canadensis

Calluna vulgaris

Ilex glabra

Ilex opaca

Acer dasycarpum

Acer pennsylvanicum

Acer rubrum

Acer saccharum

Betula papyrifera

Catalpa bignonioides nana

Catalpa speciosa

Amelanchier canadensis

Amorpha fruticosa

Aronia arbutifolia

Azalea arborescens

Azalea calendulacea

Azalea canescens

Azalea nudiflora

Azalea vaseyi

Azalea viscosa

Calycanthus floridus

Clethra alnifolia

Adiantum pedatum

Aquilegia caerulea

Aquilegia canadensis

Aquilegia chrysantha

Asclepias tuberosa

Aster alpinus

Aster novae-angliae

Baptisia tinctoria

Boltonia asteroides

Boltonia latisquama

Callirhoe involucrata

Cimicifuga racemosa

Coreopsis grandiflora

Coreopsis lanceolata

Dicentra eximia

Dicentra formosa

Echinacea purpurea

Eupatorium urticaefolium

Euphorbia corollata

Gaillardia aristata grandiflora

\section{Native Evergreen Trees}

Picea glauca conica

Picea mariana

Picea pungens

Picea pungens glauca

Pinus resinosa

Pinus strobus

\section{Native Evergreen Shrubs}

Kalmia latifolia

Leucothoe catesbaei

Pieris floribunda

\section{Native Deciduous Trees}

Cercis canadensis

Chionanthus virginica

Cornus florida

Crataegus (All varieties)

Fraxinus americana

Gleditsia triacanthos

Liquidambar styraciflua

\section{Native Deciduous Shrubs}

Cornus amomum

Cornus paniculata

Cornus stolonifera

Daphne mezereum

Diervilla trifida

Hydrangea radiata

Hypericum densiflorum

Ilex verticillata

Physocarpus opulifolius

Physocarpus intermedius

\section{Native Perennials}

Gaillardia aristata maxima

Geum chiloense atrosanguineum

Helenium autumnale

Helenium hoopesi

Helianthus decapetalus

Helianthus mollis

Heuchera sanguinea

Hibiscus moscheutos

Liatris pycnostachya

Liatris spicata

Lobelia cardinalis

Lupinus polyphyllus

Lysimachia nummularia

Mertensia virginica

Monarda didyma

Oenothera glauca fraseri

Oenothera missouriensis

Oenothera speciosa

Pentstemon heterophyllus
Pseudotsuga douglasi

Taxus canadensis

Thuja occidentalis

Tsuga canadensis

Tsuga caroliniana

Rhododendron caroliniamum

Rhododendron catawbiense

Rhododendron maximum

Liriodendron tulipifera

Malus ioensis plena

Platanus occidentalis

Quercus palustris

Salix vitellina

Ulmus americana

Rhus canadensis

Sambucus canadensis

Spiraea douglasi

Symphoricarpos racemosus

Symphoricarpos vulgaris

Vaccinium corymbosum

Viburnum americanum

Viburnum cassinoides

Viburnum dentatum

Viburnum lentago

Pentstemon laevigatus digitalis Phalaris arundinacea variegata

Phlox divaricata

Phlox paniculata

Phlox suffruticosa

Phlox subulata

Phlox subulata alba

Polemonium reptans

Polystichum acrostichoides

Rudbeckia laciniata

Rudbeckia triloba

Sanguinaria canadensis

Sedum oregonum

Sedum ternatum

Sidalcea

Thermopsis mollis

Tradescantia virginiana

Viola cucullata

Yucca filamentosa 


\section{Varieties for Special Purposes}

XYE have included the following lists in our catalog to assist our customers in selecting planting material for special purposes. This list is not complete, but we believe it will prove a valuable aid where special problems arise. We will gladly, at any time, send further information or lists to those customers who may be interested.

\section{Plants for an Old Fashioned Garden}

\begin{tabular}{l}
\multicolumn{1}{c}{ Shrubs } \\
Amorpha fruticosa \\
Clethra alnifolia \\
Forsythia intermedia spectabilis \\
Hydrangea P. G. \\
Kerria japonica fl. pl. \\
Lonicera tatarica \\
Philadelphus coronarius \\
Prunus glandulosa albiplena \\
Rhus cotinus \\
Spiraea prunifolia \\
Symphoricarpos racemosus \\
Symphoricarpos vulgaris \\
Syringa vulgaris
\end{tabular}

\author{
Zanthorhiza apiifolia \\ Althaea rosea \\ Aquilegia \\ Aster \\ Campanula medium \\ Cheiranthus allioni \\ Chrysanthemums \\ Convallaria majalis \\ Dianthus \\ Dicentra spectabilis \\ Digitalis purpurea
}

Viburnum tomentosum plicatum

\section{Herbaceous Perennials}

\author{
Gaillardia \\ Gypsophila \\ Lilium \\ Mentha \\ Myosotis \\ Paeonia \\ Papaver \\ Phalaris \\ Phlox \\ Primula \\ Rudbeckia-Goldenglow \\ Vinca minor \\ Viola \\ Yucca filamentosa
}

\section{Trees and Shrubs for Shaded Situations}

\section{Trees}

Cercis canadensis

Chionanthus virginica

Cornus florida

Cornus florida rubra

\section{Shrubs}

Acanthopanax pentaphyllum Amelanchier canadensis Aronia arbutifolia

Azalea arborescens
Azalea nudiflora
Azalea vaseyi
Azalea viscosa
Calycanthus floridus
Clethra alnifolia
Cornus amomum
Hydrangea arborescens
Ligustrum ibota
Ligustrum vulgare

Azalea arborescens

Calycanthus floridus

Clethra alnifolia

Hydrangea arborescens

Ligustrum vulgare
Lonicera fragrantissima

Lonicera morrowi

Lonicera tatarica

Philadelphus coronarius Physocarpus opulifolius

Rhodotypos kerrioides

Symphoricarpos racemosus

Symphoricarpos vulgaris

Viburnum dentatum

Viburnum lentago

\section{Evergreens for Shaded Situations}

Ilex glabra

Kalmia latifolia

Leucothoe catesbaei

Pachysandra terminalis

Pieris floribunda
Rhododendron carolinianum

Rhododendron catawbiense

Rhododendron maximum

Rhododendron hybrids
Taxus canadensis

Taxus cuspidata

Taxus cuspidata brevifolia

Tsuga canadensis

\section{Herbaceous Perennials for Shaded Situations}
Aconitum
Anemone japonica
Aquilegia
Convallaria majalis
Dicentra eximia
Dicentra spectabilis

Digitalis

Lobelia cardinalis

Lychnis chalcedonica

Lythrum

Platycodon grandiflorum
Polemonium

Primula

Veronica spicata

Vinca minor

Viola cornuta

\section{Deciduous Trees and Shrubs for Wet Places}

\section{Deciduous Trees}

Acer rubrum

Liquidambar styraciflua

Quercus palustris

Ulmus americana

\section{Deciduous Shrubs}

Aronia arbutifolia

Azalea viscosa

Calycanthus floridus

Clethra alnifolia

Cornus stolonifera
Cornus amomum

Ilex verticillata

Sambucus canadensis

Viburnum cassinoides

Viburnum dentatum

Viburnum lentago

\section{Evergreen Shrubs for Wet Places}

Berberis julianae

Cotoneaster horizontalis
Euonymus radicans and varieties Ilex glabra
Kalmia latifolia

Leucothoe catesbaei 


\section{Herbaceous Perennials for Wet Places}

Asclepias tuberosa

Aster novae-angliae

Boltonia latisquama

Cimicifuga racemosa

\section{Red Berries}

Berberis vulgaris

Berberis thunbergi

Cornus florida

Cotoneaster horizontalis

Crataegus cordata

Crataegus coccinea

Euonymus alatus

Euonymus europaeus

Ilex verticillata

Lonicera morrowi

Lonicera tatarica

Rosa rugosa

Sambucus racemosa
Helenium autumnale

Hibiscus moscheutos

Iris sibirica
Iris kaempferi

Lobelia cardinalis

Lythrum salicaria roseum

\section{Berry Bearing Trees and Shrubs}

Sorbus aucuparia

Viburnum opulus

Cornus alba

\section{White Berries}

Cornus stolonifera

Symphoricarpos racemosus

Blue Berries

Callicarpa purpurea

Cornus amomum

Deep Blue-Black Berries

Vaccinium corymbosum

Viburnum cassinoides
Viburnum dentatum

Viburnum lentago

Black Berries

Amelanchier canadensis

Aralia spinosa

Ilex glabra

Ligustrum regelianum

Ligustrum vulgare

Rhodotypos kerrioides

Sambucus canadensis

Viburnum plicatum

Viburnum lantana

\section{Trees and Shrubs for Autumn Coloring}

Acer rubrum

Trees

Acer saccharum

Cornus florida

Crataegus cordata

Liquidambar styraciflua

Quercus palustris

\section{Shrubs}

Aronia arbutifolia

Berberis thunbergi
Cornus paniculata

Euonymus alatus

Euonymus europaeus

Vaccinium corymbosum

Viburnum (all species)

\section{Shrubs and Vines for Binding and Covering Soil on Steep Banks}

\section{Shrubs}

Acanthopanax pentaphyllum

Berberis thunbergi

Lonicera tatarica

Rosa setigera
Rhus canadensis

Rosa rugosa

Rosa lucida

Sambucus canadensis

Symphoricarpos vulgaris

\section{Vines}

Celastrus scandens

Lonicera japonica

Lycium chinense

Rosa wichuraiana

\section{Trees and Shrubs for Dry Soil}

Evergreen Trees and Shrubs

Juniperus communis

Juniperus horizontalis

Juniperus sabina

Pachysandra terminalis

Pinus montana mughus

Pinus resinosa
Pinus strobus

Pinus nigra

Pinus sylvestris

\section{Deciduous Shrubs}

Acanthopanax pentaphyllum Cornus paniculata
Rhus canadensis

Rosa setigera

Symphoricarpos racemosus Symphoricarpos vulgaris

Vaccinium corymbosum

Viburnum lantana

\section{Herbaceous Perennials Suitable for Sunny or Shady Places}

\section{Sunny Places}

Achillea ptarmica

Achillea tomentosa

Asclepias tuberosa

Baptisia australis

Baptisia tinctoria

Cerastium tomentosum

Dianthus barbatus
Gypsophila paniculata

Helianthemum

Helianthus

Lupinus polyphyllus

Phlox subulata

Sedum

Sempervivum

Statice
Shady Places

Aquilegia canadensis Aquilegia chrysantha

Aster alpinus

Heuchera sanguinea

Iberis sempervirens

Platycodon grandiflorum

Sedum spectabile

\section{Ground Covers Suitable for Sunny or Shaded Places}

\section{Sunny Places}

Calluna vulgaris and varieties Juniperus communis depressa

Juniperus horizontalis

Pachysandra terminalis
Zanthorhiza apiifolia

\section{Shady places}

Euonymus radicans minimus

Hedera helix and varieties

Pachistima canbyi
Pachysandra terminalis

Taxus canadensis

Vinca minor

These are also suitable for sunny places. 


\section{INDEX}

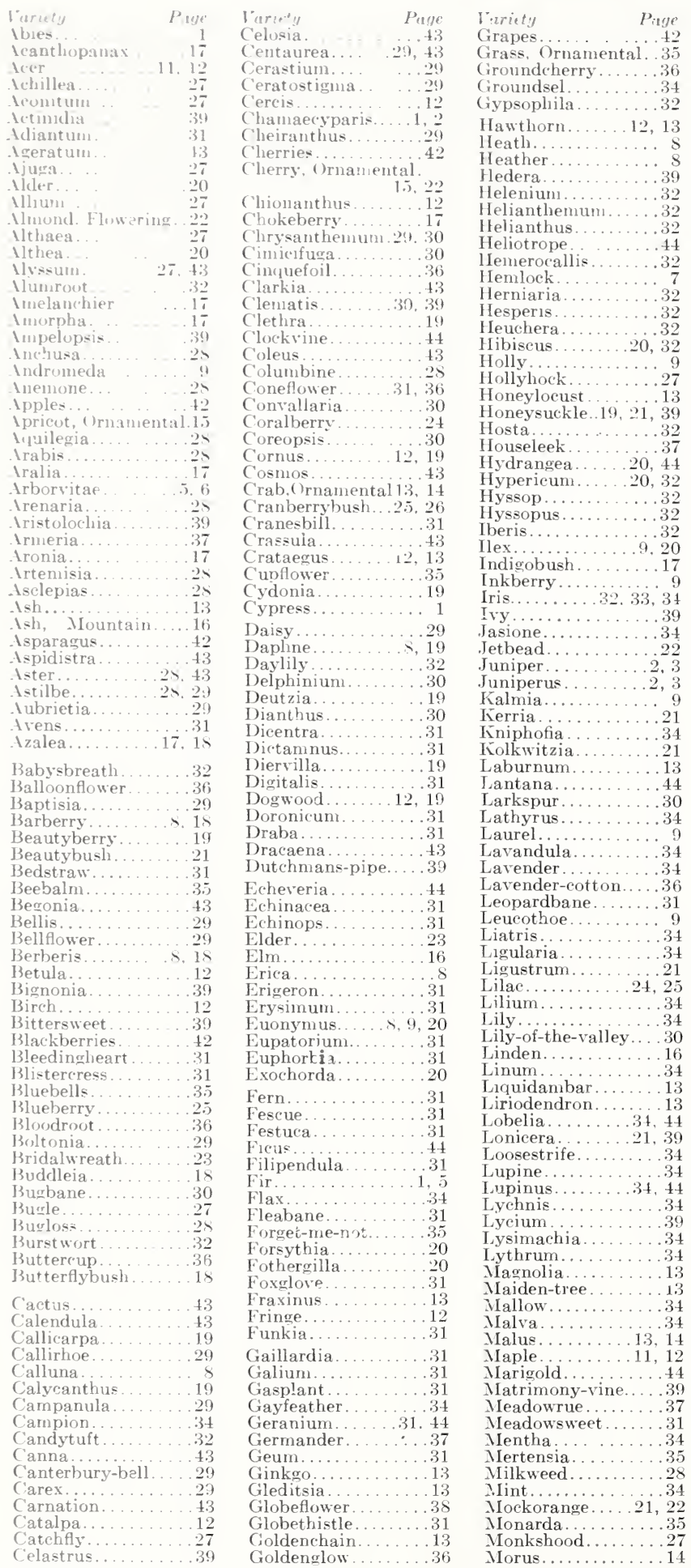

Yariety Page IIulberry............ 99 II ullein...........3s Myrtle. vierembergia .......4t Ninebark........22 Oak

()enothera

Onion..

Pachysandra.......9, Paeonia.............35 Pachistina Pansy.....

Papaver

Pea..

Peaches

Pear, Ornamental.

Pearlbush

Pelargonium

Pentstemon

Periwinkle....9. 38, 44

Persian Daisy......... 36

Petunia.......... 44

Philadelphus....21, 22

Phlox........35 36, 4

Physalis...........36

Physocarpus......22

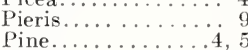

Pinus.............. 4,5

Pink. . .

4,5
.30
.32

Plantainlily

Platanus.

Platyeodon.

Plumbago.

Plum Ornamental 15.29

Plums..............442

Polystichum

Poplar.

Poppy

Poppy-mallow

Populus...

Prairiema............36

Prairiemallow..... 37,36

Primula................36

Privet.............21

Prunella......... 15.36

Pseudotsuga....... 5

Pyrethrum......... 36

Pyrus.

Quercus ........... 1

Quince, Ornamental.19

Ranunculus........36
Raspberries........42

Raspberries.........42

Pedbud.

Redcedar..........

Retinospora.........2 2

Rhodotypos..........22

Rhubarb.........42

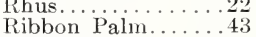

Rockeress.........28

Rocket........... 32

Rosa....... 22, 23
Rose....22, 23, 40, 41

Rosemallow,........ 32

Rubber Plant....43, 44

Rudbeckia..........36

Sage Johnswort...20,36 32 St. Johnswort..20, 32 Salix............... 16 Salvia............36, 34 Sambucus.........23 Sandwort.........28

Sanguinarı.......................

Saponaria.............37

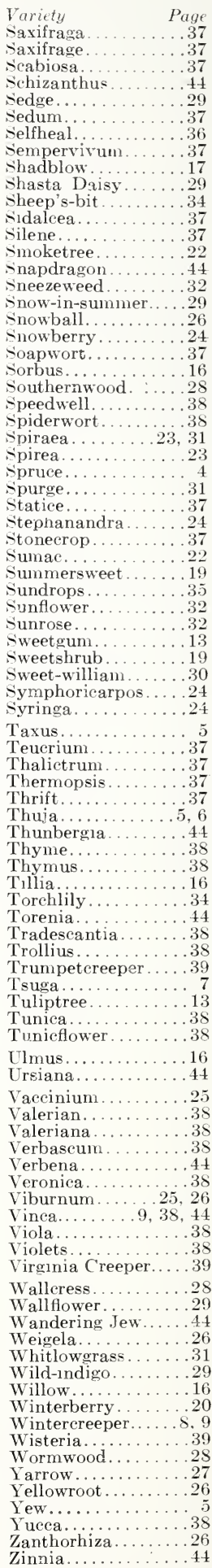

Zinnia................. 


\section{AIT ANTOUTCEN GNT}

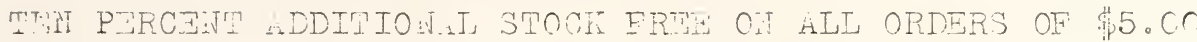

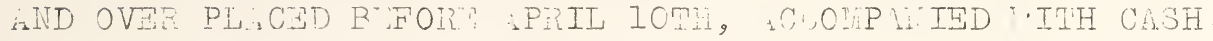

Fy receivirg as rany unders as posidile by the first week ir duril, we are able to line up our woris for spring planting. Therefors, as an incontive to our customers, we will Eive an oxtra in\% acidional stock on all orders of $5 . \cap 0$ and over placed with us before April leih, anc accompanie? with casho

free stock.

Please give a secona choice of what you desire for the

P. 3.

Please note that this Jear we are equinped as nover before to give you GULITI - SBRVICE - and IOW PRICEs 


\section{ARTISTIC GARDEN WARE}

A

RT STONE is the result of a long series of costly experiments to produce in cast stone the beautiful and everlasting qualities of natural stone. It is made by specialists in the art, with loving care and the expert skill of craftsmen. Art Stone possesses extraordinary durability. Each piece is scientifically reinforced and constructed to endure forever. The Art Stone Company is adequately equipped to make to order pieces other than those herein illustrated, from sketches or blue-prints irrespective of the intricate or delicate nature of the design. No commission is too large or too complicated for this company to undertake. Any of the Art Stone pieces shown in this catalog may be ordered in any color desired. Unless otherwise described all stock pieces are supplied in natural grey stone. Any information desired in addition to the descriptions contained herein will be gladly furnished on request.

$\overline{\text { WRITE FOR FREE ART CATALOG }}$

\section{STRAWBERRY JARS}

No. 722

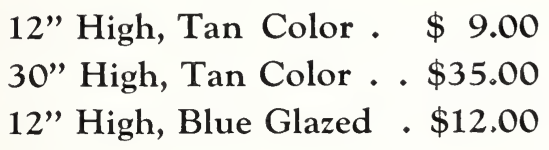

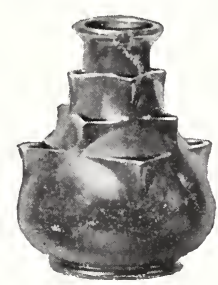

No. 716-Tan, 42" . . \$75.00

No. 724-Tan, 22” . . \$27.50

No. 734-Tan, 10 $10^{1 / 2 "}$. \$ 7.00

No. 472, 8 Inches High-Price $\$ 3.50$

Black, Blue or Green Glazed.

This jar is adapted for interior or exterior decorations. It is reasonably priced at $\$ 3.50$.

Others ranging in price from $\$ 3.50$ to $\$ 75.00$ Descriptions of all jars sent upon request.

\section{GAZING GLOBE}

Nearly every person can obtain some wonderful experiences by gazing at a spherical mirror. It produces a fascinating and deep-reaching effect and Orientals claim to see into the future. These gazing globes are imported and are made of the finest heavy weight glass lined with silver giving a permanent glitter that will never tarnish. All the air has been removed from the interior, forming a vacuum, thereby assuring absolute protection from air expansion by heat or cold which, with the ordinary globe will cause tarnishing and corrosion.

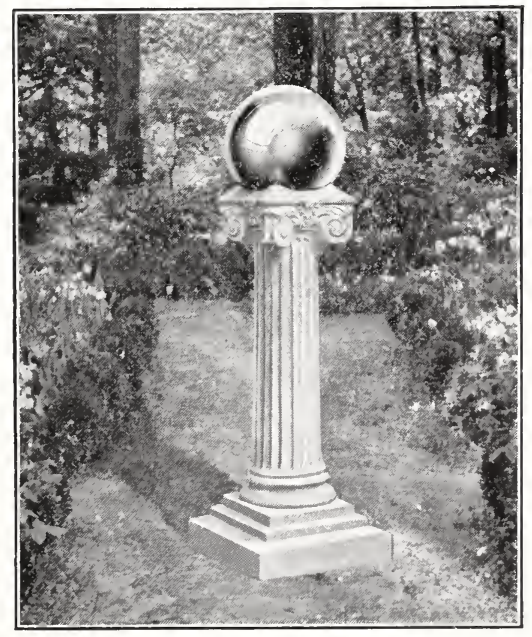

Diameters of globes are as follows:

8" Silver Gazing Globe (without pedestal)

Ea. $\$ 8.25$

10" Silver Gazing Globe

(without pedestal)

Ea. 13.00

12" Silver Gazing Globe

(without pedestal)

Ea. 15.50

14" Silver Gazing Globe

(without pedestal)

Ea. 17.50

16" Silver Gazing Globe

(without pedestal)

Ea. 23.00

Pedestals to go with Globes priced from 5.00 to $\$ 50.00$. 


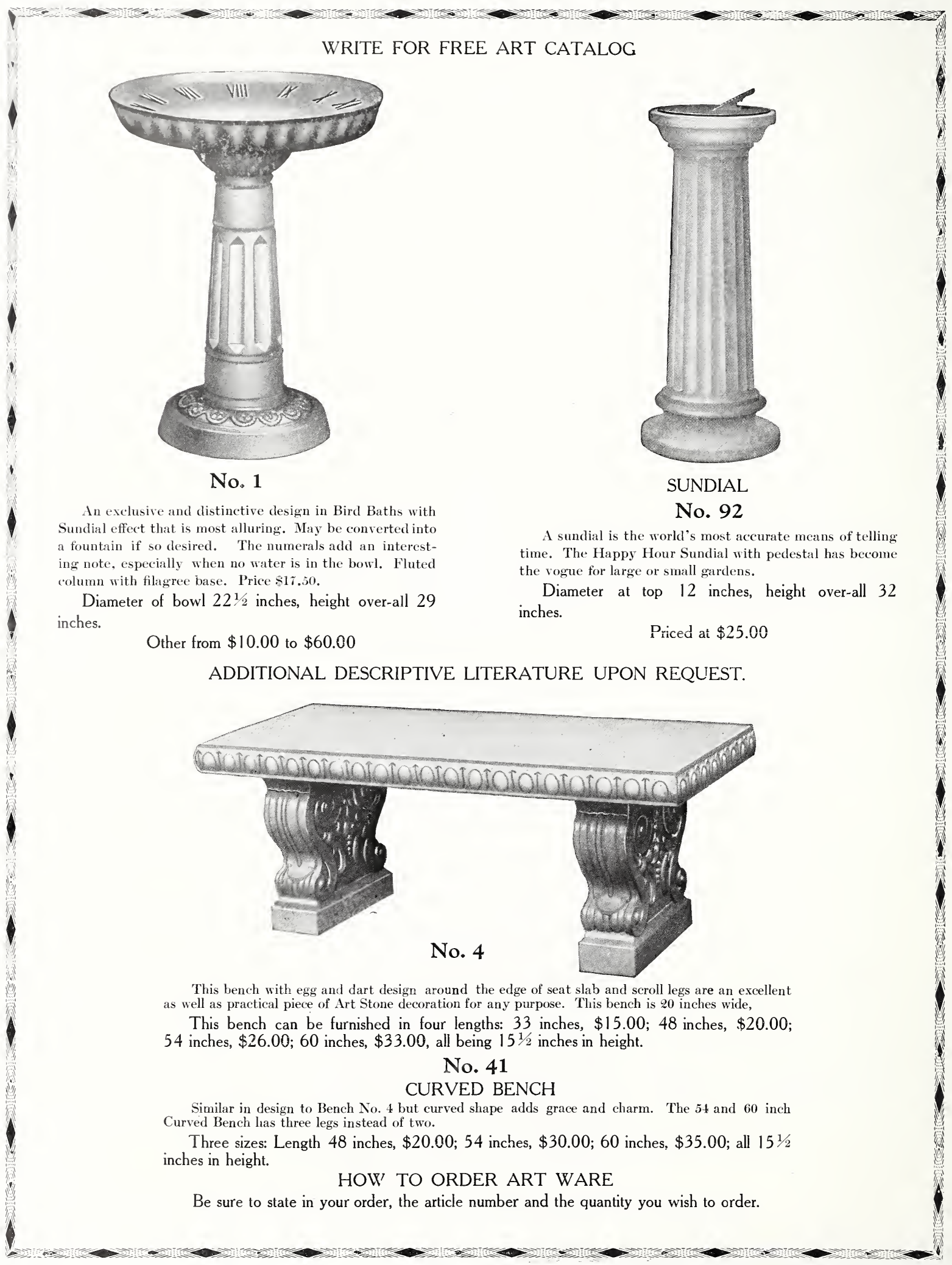




\section{Conditions of Sale \\ Please Read Before Ordering}

TERMS: We reserve the right to change priccs quoted without notice. Cash with orders for goods amounting to $\$ 10.00$ or less.

Twenty-five per cent of the total amount with orders for goods exceeding $\$ 10.00$; the goods to be shipped C. O. D. for the balance.

Charge accounts, with thirty day privilege, will be extended when suitable trade and bank refcrences are sent.

Club Plan of Payment: At the suggestion of many of our patrons, we have adopted an optional partial payment plan. The initial cost of a satisfactory planting is met in monthly payments, arranged with the customer. If you wish to adopt this method, write "Club Plan" on the order.

RATES: 1 to 4 plants of one kind and size will be priced at the single rate; 5 to 24 ,plants of one kind and size will be priced at the ten ratc; 25 plants or more of one kind and size will be priced at the hundred rate.

ADJUSTMENT: Any errors or omissions on our part will be satisfactorily adjusted if notification is given within five days after reccipt of goods.

OUR GUARANTEE: We guarantee that our stock is truc to name, vigorous and healthy at time of shipment or we replace or refund money paid, at buyer's option. We shall not be held liable for a sum greater than the original sale price.

INSPECTION: Our Nurseries are inspected yearly by an authorized State Inspector, and a copy of our certificate is enclosed with every shipment.

SUBSTITUTION: Occasionally a late order finds our stock depleted of a certain desired plant. We believe we can best serve you by making a careful substitution of the nearest match. If you prefer not to have us do this, write "No Substitution" on your order.

TRANSPORTATION: Our goods are sold F. O. B. Abington, and travel at the owner's risk and expense. Damages in transit should be taken up immediately with your Express or Freight Agent.

SHIPPING SEASON: Our Spring Shipping Season begins about March 25 th and lasts into June. The Fall Season begins in August and lasts until the ground is frozen.

TRUCKING: We will make deliveries within a radius of Two hundred miles and charge according to mileage and size of truck used. Stock so shipped arrives quickly and in as perfect condition as when it leaves our Nursery.

\section{MEMBERS OF}

American Associalion of Nurserymen

National Home Planting Bureau

New England Nurserymen's Association

Massachusetts Nurserymen's Association 


\section{LITTLEFIELD-WYMAN NURSERIES}

NORTH ABINGTON, MASSACHUSETTS 